UNIVERSIDADE DE SÃO PAULO

FACULDADE DE ECONOMIA, ADMINISTRAÇÃO E CONTABILIDADE DEPARTAMENTO DE ADMINISTRAÇÃO PROGRAMA DE PÓS-GRADUAÇÃO EM ADMINISTRAÇÃO

O USO DO LIVRO ELETRÔNICO NO ENSINO SUPERIOR SOB A ÓTICA DOS PROFESSORES UNIVERSITÁRIOS E PROFISSIONAIS DE EDITORAS

Daniel Pinsky

Orientador: Prof. Dr. Ronaldo Zwicker

SÃO PAULO 
Prof $^{\text {a }}$. Dr ${ }^{\text {a }}$. Suely Vilela

Reitora da Universidade de São Paulo

Prof. Dr. Carlos Roberto Azzoni

Diretor da Faculdade de Economia, Administração e Contabilidade

Prof. Dr. Isak Kruglianskas

Chefe do Departamento de Administração

Prof. Dr. Lindolfo Galvão de Albuquerque

Coordenador do Programa de Pós-Graduação em Administração 
DANIEL PINSKY

\section{O LIVRO DO ELETRÔNICO NO ENSINO SUPERIOR SOB A ÓTICA DOS PROFESSORES UNIVERSITÁRIOS E PROFISSIONAIS DE EDITORAS}

Dissertação apresentada ao Departamento de Administração da Faculdade de Economia, Administração e Contabilidade da Universidade de São Paulo como requisito para obtenção do título de Mestre em Administração de Empresas.

Orientador: Prof. Dr. Ronaldo Zwicker

\section{SÃO PAULO}




\section{FICHA CATALOGRÁFICA}

Elaborada pela Seção de Processamento Técnico do SBD/FEA/USP

\section{Pinsky, Daniel}

O uso do livro eletrônico no ensino superior sob a ótica dos professores universitários e profissionais de editoras / Daniel Pinsky. -- São Paulo, 2009.

$141 \mathrm{p}$.

Dissertação (Mestrado) - Universidade de São Paulo, 2009.

Bibliografia.

1. Livros eletrônicos 2. Mercado editorial 3. Inovações tecnológicas 4. Digitalização I. Universidade de São Paulo. Faculdade de Economia, Administração e Contabilidade II. Título.

CDD - 070.573 
Ao Guilherme, filho querido, a quem tenho a obrigação de entregar um mundo melhor do que recebi. À Vanessa, minha esposa. Muito obrigado por dividir os sonhos comigo e vibrar por minhas conquistas, que são nossas! 


\section{Agradecimentos}

Aos meus colegas do curso de pós-graduação, em especial Manuella, Júlio e Marcelo.

Aos professores e profissionais das editoras que me ajudaram com sua leitura atenta: José Carlos Sebe, Pedro Paulo Funari, Thais Christófaro, Luiz Trigo, Ricardo Coelho, Bruno de Carli, Alfredo Chianca, José Henrique, Gilmar, Welington Andrade, Pollyana Ferrari e Felipe Pena.

A todos os professores da USP, Mackenzie e profissionais das editoras que responderam à pesquisa.

Ao professor César, um entusiasta das inovações.

Ao professor Gilberto Perez, por me facilitar o acesso aos professores do Mackenzie.

Ao Rodrigo Velloso, Fábio Herz e Frederico Indiani, pela simpatia e atenção em responder às minhas perguntas.

Aos meus professores Liege, Ana Ikeda, Martinho Isnard, James Wright e Silvio Santos, que fizeram do cumprimento dos créditos um prazer.

Ao professor Roberto Stern, obrigado pela troca rica de ideias.

Ao meu orientador, professor Ronaldo Zwicker, por aceitar e estimular minha criatividade.

À Fia, por me dar acesso ao software Select Survey.

Agradecimentos especiais à minha "família de intelectuais":

Minha mãe, Mirna Pinsky, escritora de primeira linha, combinação única de sensibilidade e força, ao meu pai, Jaime Pinsky, cuja brilhante carreira acadêmica inspirou meus primeiros passos neste intrincado mundo, e às minhas, irmãs Ilana e Luciana, cujas inteligências aguçadas e currículos escolares de primeira linha também serviram de inspiração. 
"In the short term we tend to overestimate technology and in the long term we tend to underestimate technology." Arthur C. Clarke 


\section{RESUMO}

A digitalização e a popularização da internet podem fazer o livro impresso, que existe há mais de quinhentos anos, desaparecer em um futuro próximo. Diversos produtos pertencentes à mesma indústria de bens informativos, como a música, vêm atualmente sendo entregues pela indústria e consumidos de maneira bastante diferente de alguns anos atrás. Livros continuam sendo majoritariamente consumidos em seu formato impresso. Por quê? O principal objetivo desta pesquisa é identificar as diferenças de percepção sobre a adoção de livros didáticos eletrônicos entre professores universitários e profissionais da indústria editorial. A pesquisa utiliza o método survey e o instrumento desenvolvido por Moore e Benbasat (1991) sobre adoção de inovações. Foram pesquisadas as percepções de professores universitários e profissionais de editoras sobre a possível utilização de livros eletrônicos didáticos no lugar de impressos. As conclusões indicam que os professores estão mais preparados para a utilização de livros eletrônicos do que imaginam os profissionais de editoras. 


\begin{abstract}
The digitization and the spread of the internet may result in the extinction of the printed book, that has existed for more than 500 years. Many products that belongs to the same information industry, like thes the music, are currently being provided by the industry and consumed in radically different manners as compared to just few years ago. Books still have been consumed mainly in the printed format. Why is that? The main objective of this research is to identify the differences in perception about the adoption of electronic didactic books among university professors and publishing professionals. This research uses the Survey as its method and the instrument developed by Moore and Benbasat (1991) about the adoption of innovations. Professors' and Publishing professionals' perceptions were investigated in what it concerned the possible use of electronic didactic books replacing the printed. It is concluded that professors are more prepared to make use of electronic books than it is imagined by the publishing professionals.
\end{abstract}




\section{SUMÁRIO}

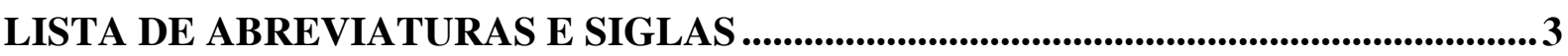

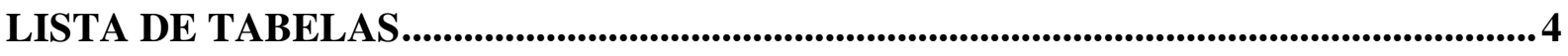

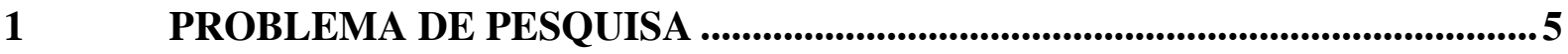

1.1 Introdução ……...........................................................................................................................................................

1.2 Definição da situação problema............................................................................................................................

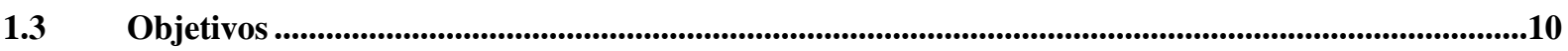

1.4 Definições teóricas e operacionais das variáveis e conceitos relevantes ..............................................10

$1.5 \quad$ Estruturação da pesquisa .....................................................................................................................................11

2 FUNDAMENTAÇÃO TEÓRICA................................................................. 13

2.1 O livro impresso, a música, a digitalização e a internet .............................................................................13

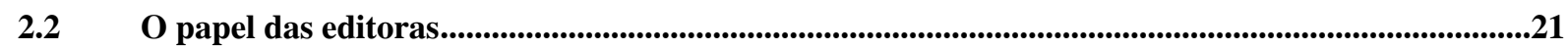

$2.3 \quad$ Setorização editorial ...........................................................................................................................................23

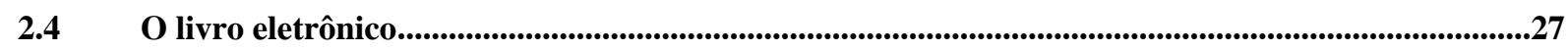

2.5 Adoção de inovação........................................................................................................................................30

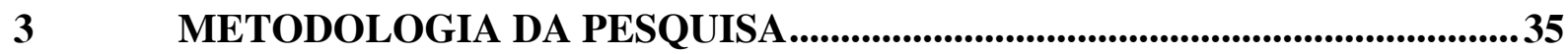

3.1 Método de pesquisa ...................................................................................................................36

3.2 Definição do universo de pesquisa ......................................................................................................................38

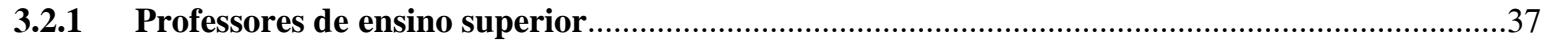

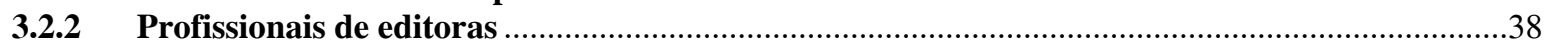

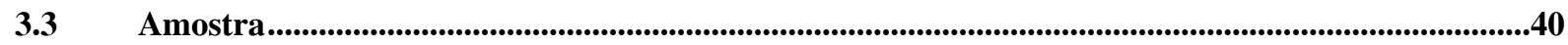

Estratégia de coleta de dados ...........................................................................................................................40

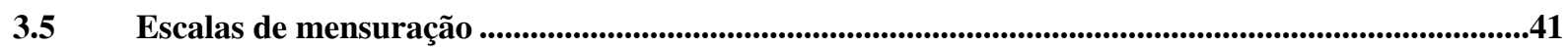

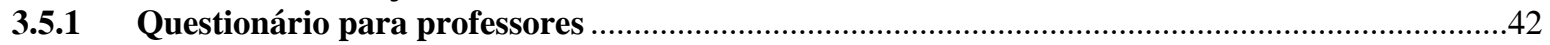

3.5.2 Questionário para profissionais de editoras …….......................................................................45

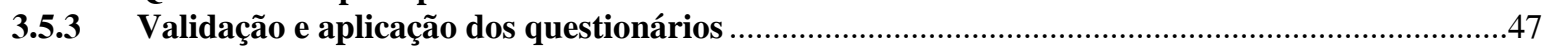

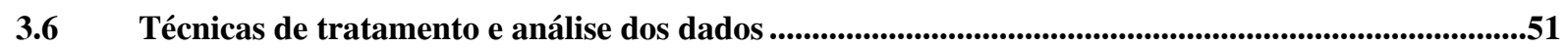

3.7 Modelo teórico-conceitual da pesquisa …………...........................................................................................52

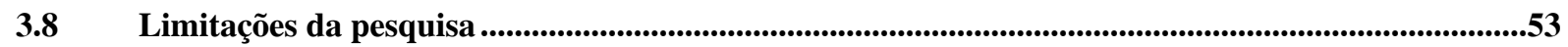


4 RESULTADOS E ANÁLISE .55

4.1 Apresentação da comparação entre as respostas dos três públicos .......................................................55

4.2 Apresentação da comparação entre os fatores.........................................................................................70

4.3 Apresentação das respostas qualitativas: Professores.................................................................................73

4.4 Apresentação das respostas qualitativas: Profissionais de editoras........................................................77

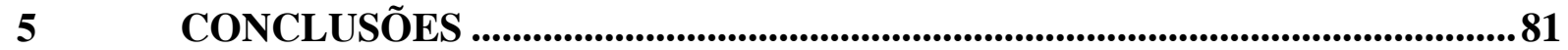

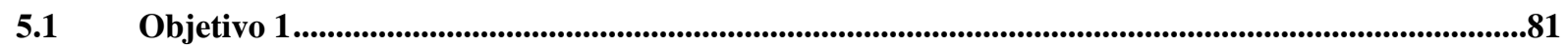

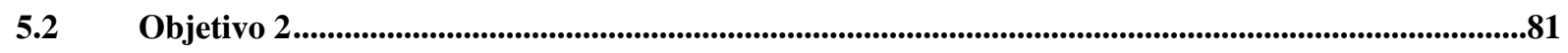

$5.3 \quad$ Objetivo 3................................................................................................................................................................83

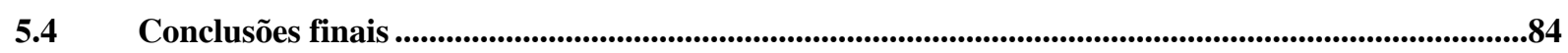

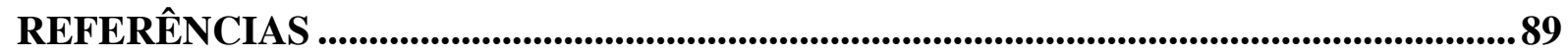

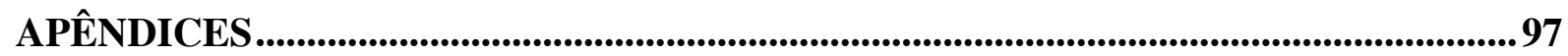

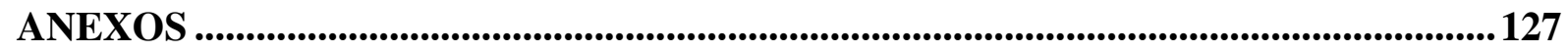




\section{LISTA DE ABREVIATURAS E SIGLAS}

ABDR: Associação Brasileira de Direitos Reprográficos

ABPD: Associação Brasileira de Produtores de Discos

CBL: Câmara Brasileira do Livro

FEA: Faculdade de Economia e Administração

IBGE: Instituto Brasileiro de Geografia e Estatística

IIS: Institut Integrierte Schalttungen

MP3: Moving Picture Experts Group 1 (MPEG) Audio Layer 3

PNAD: Pesquisa Nacional por Amostra de Domicílio

RIAA: Record Industry Association of América

SNEL: Sindicato Nacional de Editoras de Livros

STM: Scientific, Technical and Medical

UNESCO: United Nations Educational, Scientific and Cultural Organization (Organização das Nações Unidas para a Educação, a Ciência e a Cultura)

USP: Universidade de São Paulo 


\section{LISTA DE TABELAS}

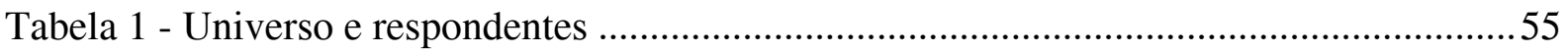

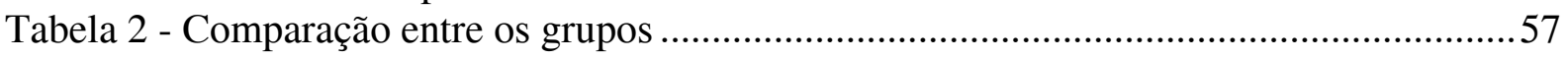

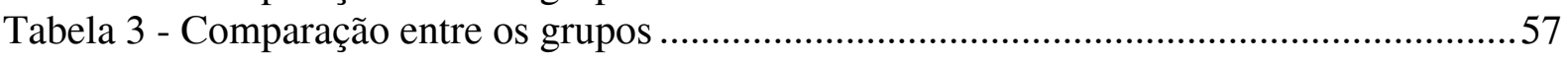

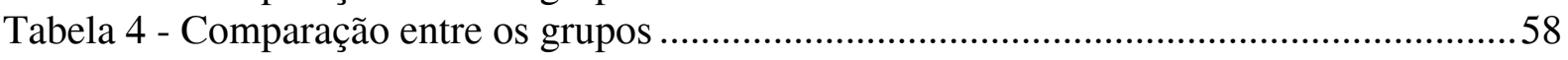

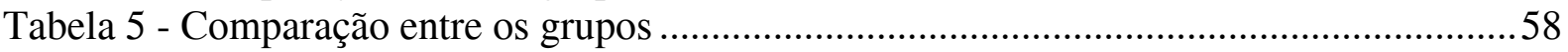

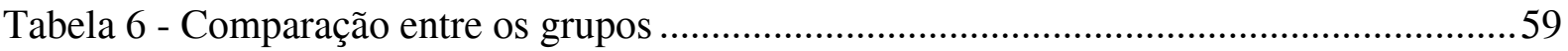

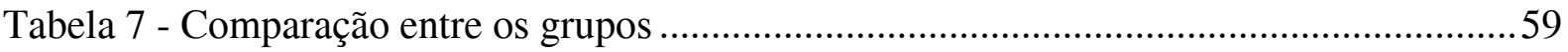

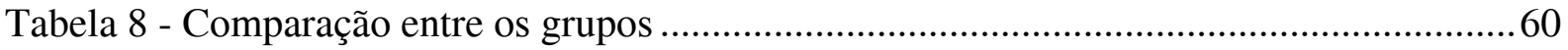

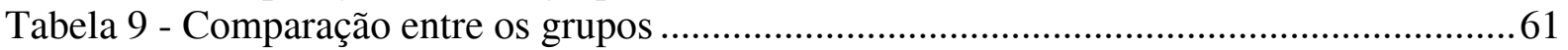

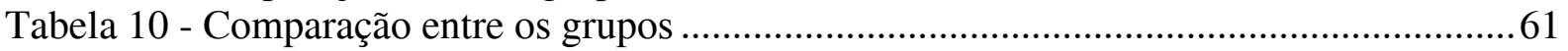

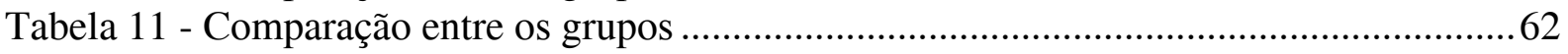

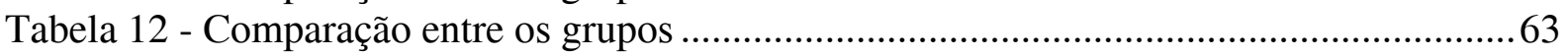

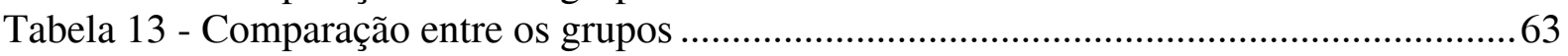

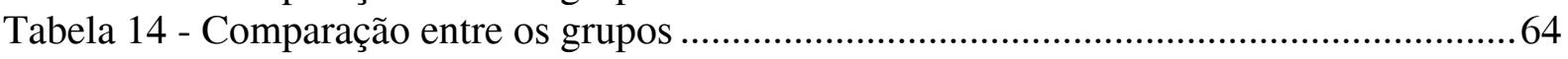

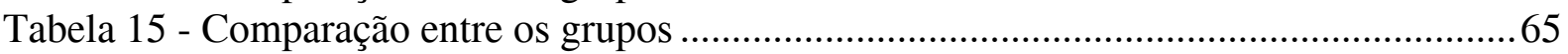

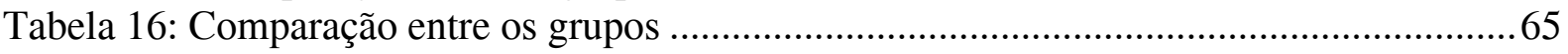

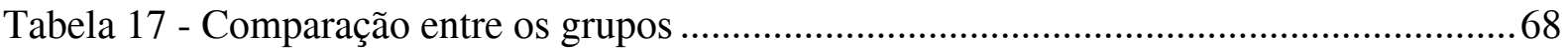

Tabela 18 - Média das variáveis e fatores .............................................................................. 71

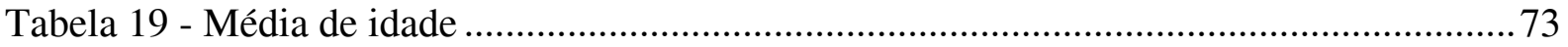

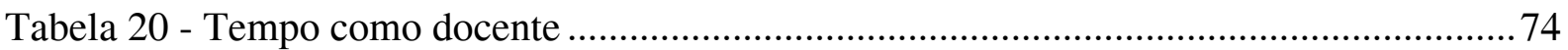

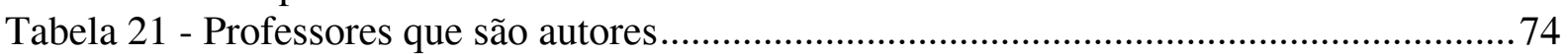

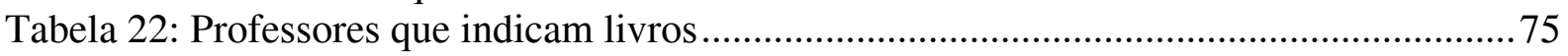

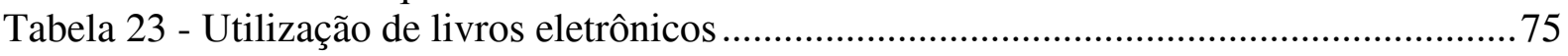

Tabela 24 - Indicação de livros eletrônicos para alunos......................................................... 76

Tabela 25 - Modelo de negócio "Pasta do Professor" ............................................................... 76

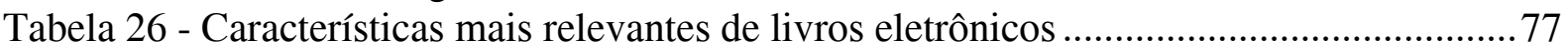

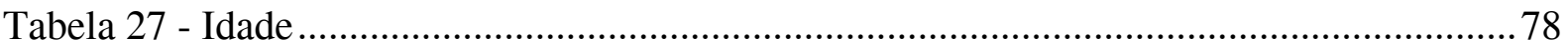

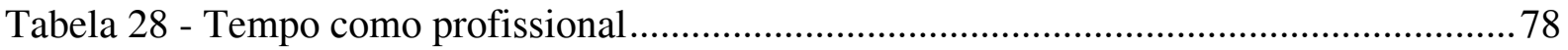

Tabela 29 - Comercialização de livros eletrônicos...................................................................79

Tabela 30 - Modelo de comercialização de livros eletrônicos. .................................................79

Tabela 31 - Motivos para pouca oferta de títulos de livros eletrônicos..................................... 80

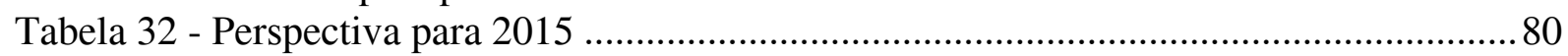




\section{PROBLEMA DE PESQUISA}

\section{$1.1 \quad$ Introdução}

O livro impresso, como concebido atualmente, tem cerca de cinco séculos. A partir da criação dos tipos móveis de Gutenberg no século XV, o conhecimento se difundiu por meio dos livros não se restringindo mais aos poucos que tinham acesso às cópias feitas à mão, portanto, raras e caras. Em torno do livro criou-se toda uma gama de atividades, como a indústria gráfica e a do papel de imprensa, por exemplo. Obras anônimas e apócrifas deram lugar a autores como Dante, Shakespeare, Cervantes e Camões, que são considerados, até hoje, referências absolutas em suas respectivas línguas.

A difusão do livro impresso também democratizou e organizou o ensino. A circulação mais ampla de riquezas, que caracteriza o período dos grandes descobrimentos (particularmente o da América), colocou parcelas maiores da população em atividades produtivas e obrigou as pessoas a "terceirizarem" a educação, colocando seus filhos nas escolas. Com isso, ocorre uma maior padronização no sistema de ensino - que não dependia mais de preceptores contratados por cada família (entre os mais ricos) - e uma difusão ainda maior do livro, responsável pela sistematização e circulação do conhecimento.

Dessa maneira, o livro impresso ganhou o mundo. E manteve-se praticamente inalterado na sua forma até o final do século XX, quando novas tecnologias começam a afetar o produto e sua cadeia produtiva.

O real impacto da digitalização no processo de produção de livros deu-se a partir da década de 1980, tornando-o mais eficiente, preciso e barato. A partir de então, as editoras, que fazem parte da chamada indústria de bens informativos como fornecedoras de conteúdo, começaram a sentir os efeitos do advento da economia digital. Alguns anos depois, com a popularização da internet e o aparecimento da rede mundial de computadores, surgiram as livrarias virtuais, que facilitaram a circulação do livro. Nos últimos anos, novas alternativas para a comercialização do próprio produto final, o livro, vêm sendo apresentadas. $\mathrm{O}$ avanço 
tecnológico já apontou várias vezes para uma possível superação do livro impresso, por obsoleto, diante do universo digital.

O termo "livro" vem sendo usado como sinônimo para a mídia e seu conteúdo por mais de quinhentos anos, o que eventualmente causa confusão. Após a leitura de um livro, se o objeto é destruído, ele continua existindo na mente do leitor mesmo tendo desaparecido fisicamente. Ou seja, é um objeto que se transforma na mente de cada leitor em uma ideia, um conceito ou universo de referências, independentemente de seu aspecto físico. O hábito da leitura, em boa parte das culturas, é relacionado a um ato individual, muitas vezes de caráter "intelectual”, sendo que para cada leitor um mesmo livro pode trazer diferentes significados. Destruir livros em massa é considerado uma "heresia", sendo que apenas sociedades obscurantistas ousaram fazê-lo. Essas características não fazem com que deixe de ser um produto, mas o fazem diferenciado.

Por conta dessa diferenciação, o livro desperta sentimentos fortes, muitas vezes afastando de seus estudiosos a objetividade para lidar com inovações ligadas a ele. Isso faz com que muitos garantam que nenhuma nova tecnologia pode substituir o prazer de folhear páginas, sentir o objeto e até cheirá-lo. No entanto, é fato que diversas empresas que publicam enciclopédias e dicionários, por exemplo, já tem modelos de negócio de sucesso em meio digital. Por outro lado, o público infanto-juvenil continua consumindo livros impressos, como provam os seguidos recordes de venda dos livros da coleção Harry Potter. Ou seja, o fato de uma tecnologia estar disponível não é garantia de que será utilizada, pois depende também de fatores socioculturais. Nesse sentido, uma pesquisa que aborda o assunto deve tomar especial precaução por conta de possíveis vieses.

Enciclopédias e livros infanto-juvenis foram usados como exemplos para demonstrar a diferença que pode haver entre dois setores da indústria editorial. Em cada um deles, a digitalização e o advento da internet têm influência diferente. Empresas de alguns setores dessa indústria já se transformaram em fornecedoras de conteúdo puramente digital. A maioria, apesar de eventuais experiências, continua tendo o formato impresso como seu principal.

Diversas indústrias de bens informativos, como a fonográfica, estão alterando seus modelos de negócio, baseando-se cada vez mais na entrega de conteúdo digital. Talvez a indústria 
editorial de livros tenha que repensar seus modelos de negócio. O livro impresso pode, em breve, não ser mais seu produto principal.

\subsection{Definição da situação problema}

A partir da década de 1980, com o uso cada vez mais intenso de computadores e o advento da internet, diversos produtos e serviços vêm sendo afetados, levando a novas maneiras de serem produzidos, comercializados e consumidos. Alguns têm sido substituídos. Diferentes indústrias vêm sofrendo impactos por conta dessas mudanças. A indústria de bens informativos, da qual a música e os livros fazem parte, começou a sofrer grandes mudanças quando seus conteúdos passaram de analógicos para digitais (SHAPIRO; VARIAN, 2003).

No caso da música, a partir de 1987, quando foi criado o formato MP3, Moving Picture Experts Group 1 (MPEG) Audio Layer 3, capaz de condensar os pesados arquivos digitalizados de sons, a indústria fonográfica vem sofrendo diversas transformações. A diminuição da importância das gravadoras e o aumento da importância das empresas de base tecnológica talvez seja a maior delas (KUSEK; LEONHARD, 2005).

Até meados dos anos 1970, livros eram produzidos basicamente por meio de processos analógicos. De maneira simplificada, o processo consistia em o escritor datilografar (ou escrever à mão), o revisor apontar os erros no papel, outro profissional realizar os pestapes (colagem das correções sobre os erros), filmar-se o original gerando um fotolito, montar uma chapa na gráfica e imprimir. Com a disseminação dos computadores pessoais nas editoras e o surgimento dos editores de texto de uso amplo, na década de 1980, esse processo começa a se modificar. O escritor passa a digitar seu original, o revisor trabalha no arquivo digital, o pestape já não é mais necessário e o fotolito vai desaparecendo, pois a impressão passa a ser gerada por meio de um arquivo digital. Essas mudanças levaram à redução de custos, agilização dos processos de produção e melhor qualidade do produto.

Ao longo da década de 1990, enquanto esse processo se desenvolvia na ponta de produção, a internet começava a se popularizar. 
A digitalização, combinada à internet, vem contribuindo para que setores inteiros da indústria editorial tenham de se adaptar, ou correr um grande risco de desaparecer, como no caso das editoras de livros de referência (enciclopédias e dicionários). A Melhoramentos, que edita o Dicionário Michaelis, ${ }^{1}$ por exemplo, possui um modelo de negócio na internet com uma combinação de acesso gratuito e propaganda. Há alguns anos, as editoras se encontram frente a uma difícil situação. A digitalização dos conteúdos, que gerou economia de custo, agilização dos processos e melhora da qualidade, pode estar levando ao fim do principal produto comercializado por elas, o livro impresso.

Nesse sentido, é importante a comparação entre editoras e gravadoras. A digitalização da música, que gerou diminuição de custos, melhoria na qualidade e abriu diversas novas possibilidades de comercialização, está, atualmente, gerando problemas para manutenção das gravadoras na cadeia de produção da indústria fonográfica. O mesmo processo pode estar ocorrendo na indústria editorial. Pesquisa realizada com 1.324 profissionais dessa área, na maior feira mundial do livro do mundo, em Frankfurt 2007 (FRANKFURT BOOK FAIR, 2007), revelou que mais da metade deles veem a digitalização como o maior desafio da área. Na pesquisa de 2008 (FRANKFURT BOOK FAIR, 2008), com cerca de 1.000 profissionais, $40 \%$ deles disseram acreditar que a venda de conteúdo digital vai ultrapassar a de livros impressos em 2018. Outro dado interessante é que 70\% dos respondentes acreditam estar preparados para os desafios da digitalização, apesar de quase $60 \%$ não trabalhar com nenhum modelo de comercialização de livros eletrônicos. As principais preocupações dos profissionais em relação à digitalização são: direitos autorais, cópias não autorizadas, formato padrão e preço de venda ao público.

Existem distintas visões quanto ao futuro do livro impresso vindas de diversas áreas do conhecimento. Burk (2001) e Liebowitz (2002) acreditam que possivelmente as publicações eletrônicas se mostrem tão bem-sucedidas que acabem com o livro em papel. Chartier (2001) acredita que as formas digital e impressa podem conviver, apesar de considerar a digitalização uma grande ruptura e uma das mais violentas mudanças na história da escrita. Para Carvalho (2006), livro impresso e eletrônico são complementares. Enquanto aquele está ligado a aprendizagem, estudo e pesquisa, este favorece a velocidade de circulação e disseminação de textos. Marcovitch (2002) crê que a palavra digital acarretará uma evolução da mentalidade,

\footnotetext{
${ }^{1}$ Ver http://michaelis.uol.com.br/
} 
em intensidade, maior do que as duas evoluções anteriores, da palavra falada para a escrita e da escrita para a impressa. E que, assim como as anteriores, aquela enriquecerá esta, sem anular suas conquistas. Para Crawshaw (2008), livros em papel já deveriam ter sido deixados no passado e substituídos por eletrônicos. De acordo com Martyns (2006) a velocidade das mudanças é discutível, mas inexorável. Borgman (2007) acredita que livros impressos continuarão sendo um mercado viável, talvez para sempre para determinados tipos de conteúdo. Ainda de acordo com o autor, a tecnologia avançou muito mais rapidamente do que nosso entendimento do presente e de seu potencial uso. Esta pesquisa pretende contribuir para ampliar esse entendimento.

Nesse sentido, é importante esclarecer que a indústria do livro é dividida em setores muito diferentes entre si em diversos aspectos (THOMPSON, 2005). Livros didáticos são afetados pelas novas tecnologias de maneira diferente de romances, que diferem de religiosos, que são afetados de maneira distinta de infantis. Um dos setores que mais vem sentindo as mudanças, e por isso mesmo com um bom potencial para pesquisa, é o de livros didáticos de ensino superior. Eles são utilizados por um público jovem, amplamente indicados por professores, além de fazerem parte de um setor em que o consumo de livros caiu nos últimos quinze anos no Brasil.

Apesar de ser uma das principais ferramentas de estudo e ensino no meio acadêmico, das grandes mudanças que vem sofrendo em termos de processo e produto, de sua importância sociocultural, do Brasil ser um dos maiores produtores de livro do mundo, a indústria editorial e o livro são pouquíssimo estudados no país. Considerando que foram encontrados poucos trabalhos acadêmicos a respeito da indústria e os escassos artigos escritos tratam de aspectos específicos, raramente com uma visão de negócios do produto, é importante que o mercado editorial brasileiro seja estudado com profundidade. Faltam teorias, e as existentes não levam em consideração as especificidades dos diferentes setores. Além disso, artigos, ensaios e reportagens que consideram o livro impresso morto ou que ele nunca irá desaparecer contradizem as evidências atuais.

Da mesma maneira que hoje existe ceticismo sobre o que vai ocorrer com o livro impresso, havia dúvidas quanto aos impactos que a impressão causaria em todas as dimensões ligadas ao livro na Europa do século XV (CHARTIER, 1998). Pode estar havendo uma ruptura da prática secular de produção e comercialização de livros impressos, tão importante quanto a 
invenção dos tipos móveis por Gutenberg. As alternativas existentes são diversas, todas relacionadas de alguma forma ao universo digital. A partir dessas considerações chega-se ao problema de pesquisa, que é: "Como profissionais de editoras de livros percebem seus consumidores em relação à utilização de livros eletrônicos?".

\subsection{Objetivos}

O objetivo principal deste trabalho é identificar as diferenças de percepção sobre a adoção de livros didáticos eletrônicos entre professores de ensino superior e profissionais de editoras.

Considerando o problema de pesquisa e o objetivo principal, foram estabelecidos os seguintes objetivos secundários:

a) Definir quais os fatores que mais interferem no processo de adoção por professores universitários de livros didáticos eletrônicos.

b) Contribuir para o desenvolvimento de uma metodologia de análise das inovações ligadas ao livro impresso.

\subsection{Definições teóricas e operacionais das variáveis e conceitos relevantes}

Teóricas:

a) Direito autoral: direito de propriedade (ou posse) de um bem intelectual (LIEBOWITZ, 2002).

b) Indústria: conjunto de empresas que competem entre si (CROWSTON; MYERS, 2004).

c) Livro impresso: volume transportável composto de ao menos 49 páginas impressas, sem contar as capas, contendo texto manuscrito ou impresso (UNESCO, 2008).

d) Percepção: ato, efeito ou faculdade de perceber ou recepção, pelos centros nervosos, de impressões colhidas pelos sentidos (MICHAELIS, 2008). 
Operacionais:

a) Bens informativos: são aqueles que podem ser digitalizados. Usualmente tem custo bem maior para serem criados do que para serem reproduzidos (SHAPIRO; VARIAN, 2003).

b) Editoras: para efeito desta pesquisa, são as responsáveis pela produção editorial e comercialização de livros impressos ou eletrônicos associadas à CBL, Câmara Brasileira do Livro, ao SNEL, Sindicato Nacional de Editoras de Livros, ou à ABDR, Associação Brasileira de Direitos Reprográficos.

c) Gravadoras: para efeito desta pesquisa, por conta de boa parte das gravadoras possuírem editoras musicais, será utilizada genericamente a palavra gravadora para definir a empresa que, normalmente, detém a posse dos direitos autorais de músicas.

d) Livro didático: "Livro que é escrito para e usado por professores e estudantes com objetivo de ensinar e aprender" (THOMPSON, 2005 p. 196).

e) Livro eletrônico: é um livro digital em arquivo texto ou sonoro que pode ser:

- Vendido (ou disponibilizado) na íntegra ou em partes.

- Alugado (por acesso pago on-line por determinado período de tempo).

- Vendido por capítulos gerados de arquivo digital, mas impressos para o consumidor em um ponto de venda (Pasta do Professor).

Nesse sentido, o importante não é como o livro será consumido (lido ou ouvido), mas sim como saiu da editora para ser comercializado.

\subsection{Estruturação da pesquisa}

O presente trabalho está estruturado em cinco capítulos principais divididos em subcapítulos.

No primeiro, problema de pesquisa, é apresentado o problema de pesquisa, definidos os objetivos e assinaladas as definições teóricas e operacionais.

No segundo é apresentada a fundamentação teórica, dividida em "o livro impresso, a música, a digitalização e a internet”, “o papel das editoras”, "setorização editorial”, "o livro eletrônico" e "adoção de inovação". 
No terceiro, metodologia de pesquisa, é apresentado o método de pesquisa e são definidos e comentados o universo e amostra da pesquisa, apresentadas a estratégia de coleta de dados e as escalas de mensuração, além de delineadas as técnicas de tratamento e análise dos dados.

No quarto, resultados e análises, são apresentados os resultados da pesquisa de campo e é realizada uma análise.

No quinto, conclusões, são apresentados os resultados finais da análise em relação a cada objetivo proposto e é um realizado um encerramento reunindo os diversos pontos apresentados ao longo desta pesquisa. 


\section{FUNDAMENTAÇÃO TEÓRICA}

Não foi encontrada nenhuma teoria que pudesse dar suporte à consecução dos objetivos desta dissertação. Por conta dessa dificuldade, o pesquisador decidiu utilizar o capítulo de fundamentação teórica não apenas para embasar a teoria, mas também para contextualizar o problema de pesquisa.

A fundamentação teórica foi dividida em cinco partes:

a) O livro impresso, a música, a digitalização e a internet: são apontadas as semelhanças e diferenças entre o livro impresso e a música e detalhados os principais impactos que a digitalização e a internet vêm causando na indústria fonográfica e editorial.

b) O papel das editoras: é apresentada a importância das editoras na cadeia produtiva do livro.

c) Setorização editorial: é apresentado o conceito de setorização editorial, fundamental para enquadramento e entendimento do problema de pesquisa.

d) O livro eletrônico: é traçado um histórico do produto, chegando-se à definição conceitual utilizada na pesquisa de campo.

e) Adoção de inovação: é apresentada a teoria da difusão de inovação e o instrumento utilizado na pesquisa de campo.

\subsection{O livro impresso, a música, a digitalização e a internet}

Apesar de ser apontada como possível fonte de diferencial competitivo nos negócios, tecnologia isoladamente não garante uma vantagem. Porter (1989) afirma que a tecnologia afeta a vantagem competitiva se tiver um papel significativo na determinação da posição do custo relativo ou diferenciação, mas sozinha não garante rentabilidade. Muitas indústrias que utilizam alta tecnologia são menos rentáveis do que algumas que usam "baixa tecnologia". Segundo Cope e Kalantzis (2001), o desenvolvimento tecnológico dissociado de outros fatores representa muito pouco. A menos que a tecnologia se combine com forças socioculturais e econômicas de mudança, a sua influência será pequena. Furtado (2004) reforça a necessidade do estudo de fatores históricos e sociológicos na análise de uma 
mudança tecnológica. De acordo com Borgman (2007), fatores sociais podem ter profundas influências sobre como tecnologias se desenvolvem. Ou seja, o fato de uma tecnologia estar disponível não faz com que ela seja necessariamente mais utilizada ou desejada pelos consumidores, ou mesmo rentável para as empresas.

Os primeiros computadores digitais surgiram na década de 1940, construídos pelo exército americano. A primeira versão comercial, o Univac1, só chegou ao mercado em 1951 (CASTELLS, 1999). No entanto, somente a partir do final da década de 1960 é que se pode falar de uma economia digital na qual os computadores, com capacidade de processamento cada vez maior, têm um papel vital (TAPSCOTT, 1996). A ampliação da importância dos computadores e sua lógica digital só foram possíveis por conta da queda de preços considerável e aumento da capacidade de processamento, seguindo os preceitos da Lei de Moore, ${ }^{2}$ formulada em 1965 por Gordon Moore.

O uso de computadores nas empresas afetou processos e produtos. De acordo com Castells (1999), a revolução da tecnologia da informação é um evento histórico, comparável à revolução industrial. Eventos como esse são caracterizados por sua penetrabilidade, sendo voltados para processos, além de induzir a criação de novos produtos. Desde processos simples, como cálculo de faturamento, até avançados, que envolvem diversas unidades ou departamentos de uma empresa, foram afetados. Produtos também sofreram alterações importantes em diferentes intensidades. Segundo Porter e Millar (1985), quanto maior a intensidade de informação em um produto, maior a probabilidade de a tecnologia ter papel estratégico. Indústrias de bens informativos, por definição, são as que possuem a maior intensidade de informação em seus produtos. Dessa indústria fazem parte a música e o livro.

Uma outra tecnologia que mudou profundamente processos e produtos foi a internet. Ela surgiu na década de 1960 com o nome de Arpanet, desenvolvida pelo departamento de defesa dos Estados Unidos. No entanto, somente em 1990, com a invenção da rede mundial de computadores pelo Centro Europeu de Pesquisas Nucleares, que os sítios passaram a ser organizados por informação e não por localização. A partir de 1993, a internet começava a se popularizar (CASTELLS, 1999).

\footnotetext{
${ }^{2}$ Lei de Moore: Gordon Moore previu que os computadores dobrariam sua velocidade a cada 18 meses e ao mesmo tempo se tornariam mais baratos (GOMEZ, 2008).
} 
O advento da internet fez com que o custo de distribuição dos produtos ligados à informação caísse muito, podendo ser realizada de maneira rápida e fácil. De acordo com Tapscott (1996), a partir do momento em que a informação pôde ser digitalizada e enviada por rede, uma enorme gama de novas possibilidades se abriu. A combinação das duas tecnologias afetou profundamente o mundo dos negócios.

Novas tecnologias que afetam de maneira radical as indústrias vêm sendo estudadas por acadêmicos de diversas áreas. De acordo com Christensen e Bower (1995), tecnologias disruptivas são aquelas que alteram a relação de forças dentro de uma indústria. Um avanço em determinada tecnologia pode mudar completamente o modelo comercial de toda uma indústria e não somente de empresas isoladas (ORLIKOWSKI; BARLEI, 2001). Alterações na natureza dos produtos podem levar a mudanças na base da competição entre empresas e em indústrias inteiras (CROWSTON; MYERS, 2004). De acordo com McLuhan (1977, p. 214), novas tecnologias " [...] tem o poder de amortecer a atenção consciente do homem no período inicial [...]". A digitalização e a internet são exemplos desse tipo de tecnologia para a indústria de bens informativos.

De maneira geral, a informação é cara de produzir, mas barata de reproduzir. Com a digitalização e a possibilidade de produção de cópias perfeitas, esse custo caiu ainda mais, chegando próximo a zero. Ou seja, a economia da informação tem a ver com a informação, mas está intimamente ligada à tecnologia (SHAPIRO; VARIAN, 2003).

A indústria da música vem sendo bastante afetada pela digitalização e advento da internet. Em 1987, o IIS, Institut Integrierte Schalttungen, juntamente com a Universidade de Erlagen desenvolveu o que hoje é conhecido como MP3. Um dos principais objetivos era conseguir reproduzir som com qualidade de $\mathrm{CD}$ e taxa de compreensão razoável. Apesar da digitalização de músicas já existir havia alguns anos, foi a partir dessa tecnologia que diversas novas possibilidades começaram a se abrir para a indústria fonográfica.

Em 1999 foi criado o Napster, software que permitia a troca eletrônica de arquivos digitais entre qualquer pessoa com acesso à internet, auxiliando o internauta a encontrar o que lhe interessava. Era principalmente usado para troca de músicas em formato digital, sem autorização dos detentores dos direitos autorais, normalmente as gravadoras. 
O caminho encontrado pelas gravadoras em vista da ameaça que a combinação de novas tecnologias representava foi o enfrentamento. Processaram e, ao final de uma longa batalha jurídica, venceram o processo contra o Napster. No entanto, enquanto as gravadoras, representadas pela RIAA, Record Industry Association of América, lutavam contra o Napster, outros softwares como Kazaa e Grokster estavam sendo idealizados. Como esses softwares não controlavam um banco de dados central, mas sim possibilitavam que usuários trocassem arquivos entre si, a RIAA perdeu os novos processos decidindo, então, processar os usuários (GORDON, 2005). A descentralização do processo com os novos softwares fez com que os novos usuários fossem cada vez mais difíceis de serem identificados (TAYLOR, 2006). As gravadoras venceram algumas pequenas batalhas, mas a guerra estava sendo perdida.

Enquanto as gravadoras batalhavam nos tribunais, a Apple, que havia criado o Ipod em 2001, ajudava a popularizar ainda mais o consumo de música digital transferida da internet. $\mathrm{O}$ aparelho reproduz músicas que podem ser copiadas de seu sítio em formato Mp3, pagando-se alguns centavos de dólar por faixa. Com a popularização do Ipod, a utilização de sítios dos quais se pode transferir música, paga ou gratuitamente, explodiu (GORDON, 2005). O Ipod surpreendeu as gravadoras e, atualmente, a indústria de base tecnológica detém a força nesse mercado (MARTYNS, 2006).

No Brasil, segundo a ABPD, Associação Brasileira de Produtores de Discos, houve uma queda de 54\% no faturamento das gravadoras entre 2002 e 2007. Em relação à musica digital, de acordo com pesquisa do Instituto Ipsos Insight (2006), foram baixadas 1,1 bilhões de músicas por cerca de 3 milhões de internautas em 2005. Quase a totalidade delas de maneira ilegal, ou seja, sem remunerar os detentores dos direitos autorais. Nos Estados Unidos, segundo estudo da RIAA (2007), houve uma queda de $28 \%$ no faturamento das gravadoras entre 2000 e 2007. De acordo com o mesmo estudo, o faturamento das gravadoras americanas com conteúdo digital em 2007 foi de 2,3 bilhões de dólares. Isso representa um crescimento expressivo de $216 \%$ em relação a 2005 chegando a representar $23 \%$ do total faturado pela indústria. No entanto, ainda insuficiente para deter a queda do faturamento total. 
A possibilidade de digitalizar e comprimir músicas, aliada à criação de softwares, a disseminação do acesso à internet e a criação do Napster geraram uma nova cultura do consumo de música (KUSEK; LEONHARD, 2005). As gravadoras enxergaram a ameaça que a digitalização e a internet representavam. Mas foi a indústria de base tecnológica que enxergou a oportunidade e, pelo menos por enquanto, está mais bem posicionada nessa indústria de bens informativos. A realidade atual é que o negócio da música vai muito bem, são apenas as gravadoras e seu modelo de negócio que vão mal (KUSEK; LEOHARD, 2005).

O Gráfico 1 apresenta o faturamento das gravadoras brasileiras entre 2002 e 2007.

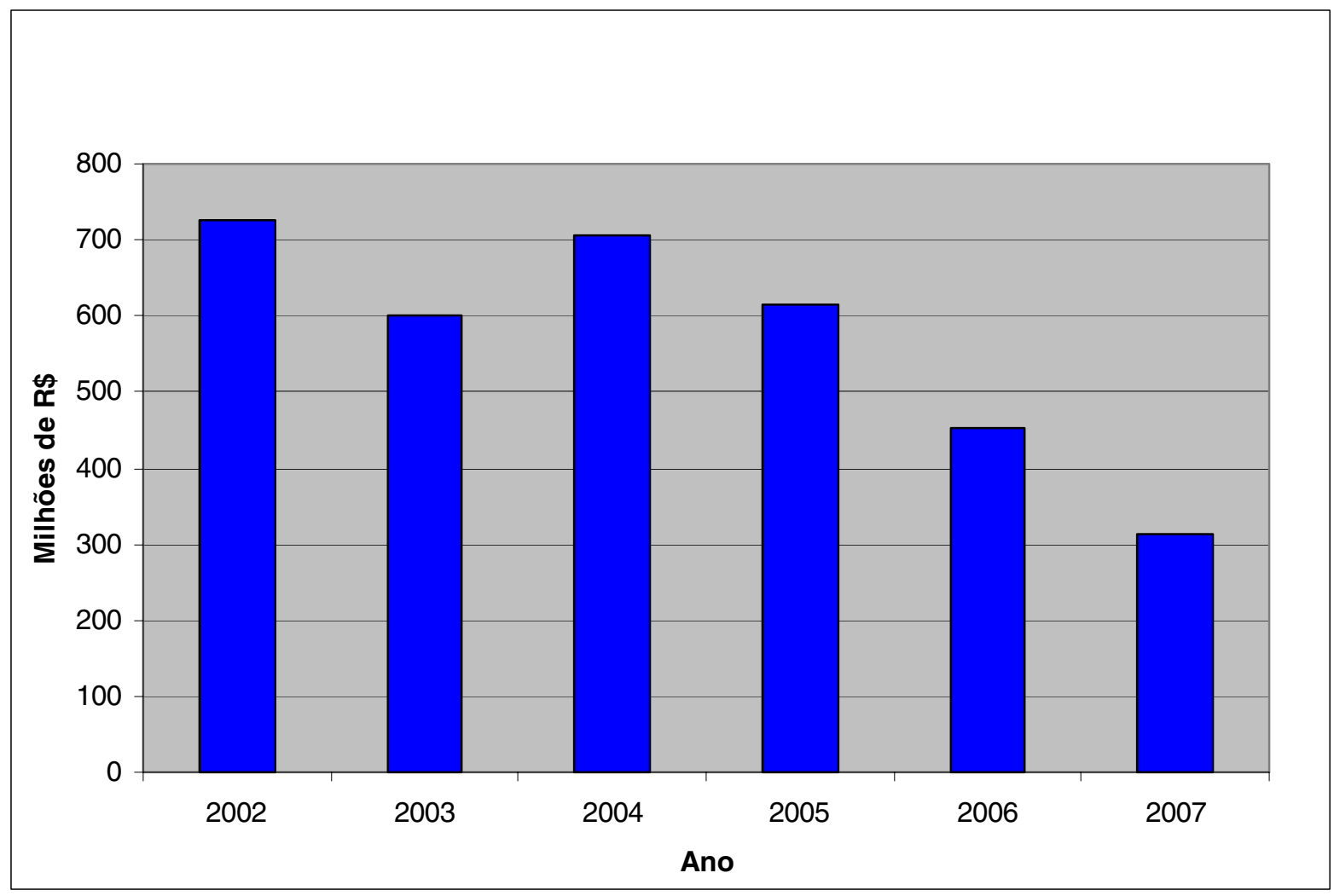

Gráfico 1 - O faturamento das gravadoras brasileiras FONTE: ABPD, 2008

O faturamento das gravadoras vem diminuindo por conta da pirataria de CDs e DVDs e da oferta de conteúdo digital não controlado (ABPD, 2008). Os dois fatores estão ligados à digitalização do conteúdo e ao seu baixo custo de reprodução.

O produto livro tem diversas semelhanças com a música. Ambos fazem parte da indústria de bens informativos, são afetados pelas cópias não autorizadas, diversos tipos de livros podem 
ser vendidos aos pedaços (como faixas de CDs) e, por serem digitalizáveis, podem ser consumidos em diversos tipos de mídia. Conteúdo publicado sempre foi independente do produto físico que o suporta. A digitalização só tornou isso mais claro (KASDORF, 2003). Além disso, as editoras e gravadoras têm em comum o fato de, na maior parte dos casos, não produzirem conteúdo.

Apesar das semelhanças entre as indústrias fonográfica e editorial, há uma diferença que, pelo menos até hoje, impediu que acontecesse com as editoras o que vem ocorrendo com as gravadoras. E essa diferença não está ligada diretamente à tecnologia, mas sim a preferências socioculturais. Hoje o papel é a mídia preferida para a leitura de livros, como comprova o estudo Produção e Vendas do setor editorial brasileiro (2006), que sequer inclui vendas de livros digitais por considerá-las irrelevantes. Até mesmo a definição da lei do livro brasileira ou a definição de livro pela UNESCO, Organização das Nações Unidas para a Educação, a Ciência e a Cultura, não considera arquivos digitais de nenhuma espécie como livros. Segundo pesquisa realizada pela Zogby International (2008), 0\% dos americanos compram com mais frequência livros digitais do que livros em qualquer outro formato. De acordo com Martyns (2006), a venda de livros digitais não atinge 1\% das vendas dos livros impressos no mundo. Em contato com conteúdos digitais mais longos, a maior parte dos leitores imprime textos mesmo que para ler alguns poucos parágrafos. Pouquíssimos leem livros em uma tela (BORGMAN, 2007).

O livro impresso tem mais de quinhentos anos. É um dos produtos que menos transformações sofreu ao longo de sua história, sendo pouco afetado pela criação de diversas novas tecnologias. No entanto, continua sendo um dos melhores meios para se armazenar e transmitir informações. Segundo Marcovitch (2002, p. 7), é "a melhor arma contra ignorância". Livros são o melhor meio para analisar tendências de longo prazo e distinguir entre meios e fins, além de carregarem muitas das maiores ideias da humanidade (BORGMAN, 2007).

Por outro lado, apesar da preferência de consumo do produto livro atualmente ser em papel, alguns dados apontam para a possibilidade de mudança nessa preferência. $\mathrm{O}$ número de internautas ativos $^{3}$ no Brasil cresceu de 4,9 milhões em 2000 para 24,8 milhões em 2009 e

\footnotetext{
${ }^{3}$ Pessoas com 2 anos ou mais que navegaram na internet através de computadores no domicílio no mês no país.
} 
62,3 milhões ${ }^{4}$ tiveram acesso à rede em fevereiro deste ano (IBOPE/NETRATINGS, 2009). De acordo com a mesma pesquisa (2007), 87\% dos jovens de 16 a 24 anos têm acesso à internet. Segundo a PNAD, Pesquisa Nacional por Amostra de Domicílio, do IBGE, Instituto Brasileiro de Geografia e Estatística, realizada em 2007, 20,2\% dos domicílios brasileiros tem microcomputadores com acesso à internet. De acordo com a mesma pesquisa de 2005, 33,9\% dos jovens na faixa dos 15 aos 17 anos tinham acesso à internet. Pesquisa do Cetic (2007) revela que $68 \%$ dos jovens brasileiros de 10 a 15 anos haviam usado um computador pelo menos uma vez nos três meses anteriores à pesquisa contra $43 \%$ em 2005 . Na faixa etária de 16 a 24 anos, o percentual em 2007 era de 65\%, contra 54\% dois anos antes. A pesquisa Retratos da Leitura do Brasil (INSTITUTO PRÓ-LIVRO, 2008) revela que 3\% do universo da pesquisa, ${ }^{5}$ ou seja, 4,6 milhões de pessoas leem livros digitais e mais de $20 \%$ tem como hábito a leitura de textos na internet. Outro dado importante é que na faixa de 14 a 17 anos, $15 \%$ da população leitora ${ }^{6}$ copia livros da internet, contra $3 \%$ da faixa compreendida entre 40 e 49 anos. Outro estudo, encomendado pelo Google à IBOPE/Netrating (VALOR ECONÔMICO, 2009) informa que o Brasil fechou 2008 com 43 milhões de pessoas com acesso à internet. Segundo o estudo $81 \%$ da base de entrevistados fazem pesquisa escolar na rede internacional de computadores.

Com um maior uso de computadores e acesso à internet por parte da população (principalmente da faixa mais jovem), há um aumento da familiaridade com o universo digital. E uma maior familiaridade pode levar a uma ampliação da leitura de livros eletrônicos, eventualmente substituindo os impressos. Ou seja, a principal diferença sociocultural entre as indústrias fonográfica e editorial, que é a mídia por meio da qual são preferencialmente consumidos, pode diminuir ou até mesmo desaparecer em um futuro próximo. Indústrias de base tecnológica como Google, Microsoft e Yahoo já declararam sua intenção de mover-se para o mercado de livros por acreditar nessas mudanças. E possuem tecnologia, capital, capacidade e alinhamento com o consumidor para causar um grande impacto (MARTYNS, 2006).

De acordo com Taylor (2006) um dos estímulos ao fornecimento de conteúdo digital pelas editoras aos seus consumidores é evitar o que vem ocorrendo com as gravadoras. A demora

\footnotetext{
${ }^{4}$ Usuários que têm acesso à rede em qualquer ambiente.

5172,7 milhões de pessoas ou $92 \%$ da população.

${ }^{6}$ 95,6 milhões de pessoas de acordo com a pesquisa.
} 
em adotar um modelo de negócios com distribuição de conteúdo digital vem fazendo com que as gravadoras sejam cada vez menos importantes na cadeia produtiva da música.

Alguns setores da indústria editorial, como o de livros de referência, já vêm sentindo as mudanças de hábito de seus consumidores e hoje publicam principalmente conteúdo digital. As editoras estão cientes de que oferecer um produto digital não é um grande salto tecnológico, já que o produto original está em meio digital, no entanto, é um grande salto cultural (TAPSCOTT, 1996). Costumes ou tradições são obstáculos a serem superados na adoção de novos produtos ou serviços ligados à tecnologia. Mas culturas mudam e as novas tecnologias têm o poder de eventualmente mudar hábitos bastante conservadores (COSTA FILHO et al., 2007; GOMEZ, 2008). Ou seja, a barreira que até hoje vem sustentando a mídia livro impresso como principal formato para o livro conteúdo, pode estar desaparecendo por conta de mudanças culturais.

Segundo Thompson (2005), a digitalização pode causar impacto na indústria editorial em quatro níveis:

a) Sistemas operacionais: sistemas de operação e gerenciamento das empresas, desde softwares de gestão até planilhas eletrônicas.

b) Gerenciamento e manipulação de conteúdo: com a digitalização ficou mais claro para os editores que são fornecedores de conteúdo o fato de que esse é seu principal ativo, e não livros em papel. Diversas etapas da produção de um livro são feitas em meio digital.

c) Provisão de serviços e marketing: com o surgimento da internet muitos editores criaram sites para se comunicar e prover serviços diretamente a seus clientes.

d) Entrega de conteúdo: é o nível no qual a digitalização tem seu maior potencial de mudança e o mais difícil de decifrar.

Para que possa haver foco, aprofundamento do conhecimento, pelo seu maior potencial de mudança e por ser o nível mais difícil de decifrar, optou-se por trabalhar, nesta pesquisa, com o nível de entrega de conteúdo. 


\subsection{O papel das editoras}

De maneira simplificada o processo de produção de um livro é apresentado na Ilustração 1:

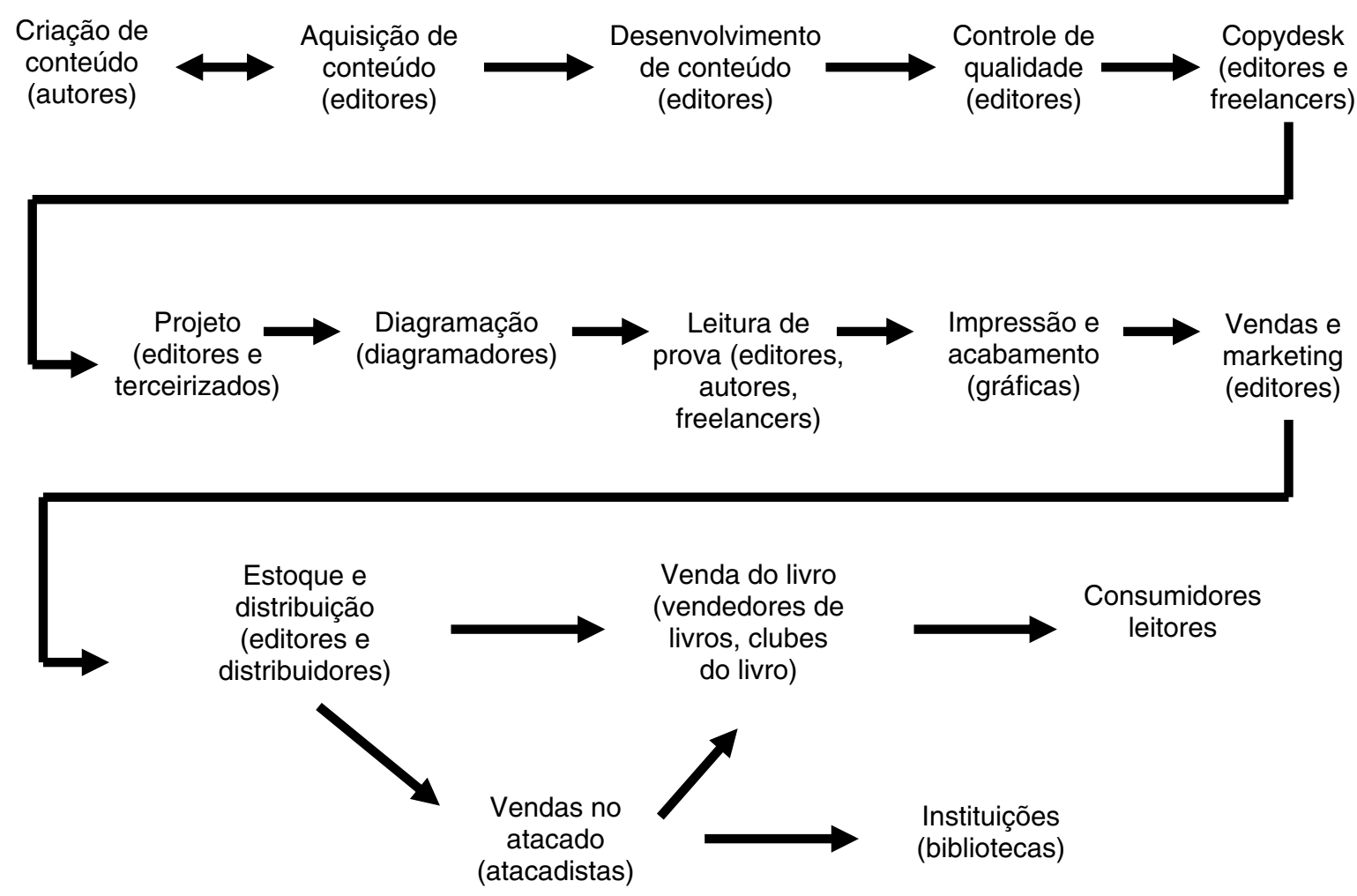

Ilustração 1 - O processo de produção do livro FONTE: Adaptado de THOMPSON (2005, p. 21)

Não existe necessidade de uma editora para que esse processo exista. Com a digitalização e a popularização da internet ele foi simplificado e barateado, fazendo com que apenas publicar não seja um diferencial competitivo.

Qualquer que seja a forma com a qual uma editora pretenda trabalhar, ela deve buscar um diferencial, pois a tecnologia da informação possibilita a qualquer um publicar, no sentido de tornar público seu trabalho (BORGMAN, 2007). Isso significa que as editoras não podem ter mais como função principal apenas a publicação de livros. As editoras que tiverem como modelo de negócio fazer ajustes nos textos recebidos, diagramá-los, solicitar a impressão e enviá-los para as livrarias possivelmente se transformarão em simples intermediárias. E 
intermediários que não agregam valor, segundo Tapscott (1996), vão desaparecer com a chegada da digitalização e da internet.

De acordo com Epstein (2002), apesar de a tecnologia alterar o modo como livros são distribuídos, o trabalho do editor será sempre fundamental. $\mathrm{O}$ autor necessita do editor para melhorar seu texto e facilitar o diálogo com o leitor, pois tem interesse em atingir o maior público possível. Quer seja por questões financeiras, porque deseja que seu trabalho seja mais conhecido e influente ou pelos dois motivos.

O editor não apenas decide o que será publicado ou não. Ele identifica espaços no mercado e dá ideias sobre que livros publicar, analisa a concorrência, conhece o público consumidor, busca o melhor escritor possível para dar andamento a determinada ideia (THOMPSON, 2005). O bom editor, principalmente em um universo digital, não trabalha como um simples intermediário que se preocupa apenas com a forma e os aspectos gramaticais e ortográficos do conteúdo. Ele é aquele que conhece não apenas o conteúdo oferecido pelos autores, mas também seu público consumidor. Ou seja, o papel do editor é cada vez mais agregar valor ao conteúdo. Publicar é simples, publicar bem e adequar o texto ao público consumidor é mais complicado.

Porém, editores não são os únicos a acrescentar valor no caso de empresas editoriais. Editoras realizam o trabalho de divulgação e distribuição, essencial para que um produto possa eventualmente se destacar em meio a uma quantidade enorme de livros lançados e informações disponíveis. Além disso, publicar em determinadas editoras é sinal de prestígio em diversos setores, principalmente no mundo acadêmico (THOMPSON, 2005).

Apesar de editoras acrescentarem valor em diversos pontos da cadeia produtiva do livro, é no trabalho com o conteúdo que grande parte delas apresenta uma vantagem competitiva. Isso porque livros fazem parte da indústria de bens informativos, tendo, por definição, uma maior intensidade (ou importância) de informação em seus produtos. De acordo com Marques (1999), principalmente a partir de 1970, houve uma aceleração no aumento do trabalho sobre a informação. $\mathrm{O}$ autor afirma que parece natural para o consumidor pagar mais pela informação do que pelo material, no caso de livros. Por conta da lógica do capitalismo, os agentes econômicos buscam oferecer produtos mais "leves", que carreguem em si mais 
“pesquisa e desenvolvimento". Ou seja, cada agente econômico deve encontrar a sua posição na oferta de bens e serviços.

Pode-se constatar a importância da existência das editoras para a cadeia produtiva do livro checando-se a lista de livros mais vendidos publicadas por diversas revistas, jornais e livrarias. Na semana de 9 a 15 de março de 2009, todos os livros das listas de mais vendidos das revistas Veja (2009), Época (2009) e IstoÉ (2009), dos jornais O Estado de São Paulo (2009), Folha de S.Paulo (2009), O Globo (2009), das livrarias Cultura (2009), Saraiva (2009) e do Submarino (2009) eram comercializados por editoras.

Apesar de existirem diversos modelos de negócio para publicação própria, é muito difícil se conseguir uma boa exposição nas livrarias e boa divulgação sem o trabalho de uma editora. Editoras são importantes, pois auxiliam na circulação de ideias, divulgam a cultura, são um canal para manifestação de diversos pontos de vista e, principalmente, no meio acadêmico, por fornecerem "selos de qualidade" às publicações (THOMPSON, 2005). Elas, em sua grande maioria, não imprimem seus livros. Assim como diversos outros segmentos industriais, a impressão (ou materialização) do livro é terceirizada. Editores tem cada vez mais como função principal agregar valor ao texto, emprestar seu prestígio, legitimar e auxiliar na disseminação do produto final (THOMPSON, 2005). É possível que surjam modelos de negócio que levem a uma desintermediação de pelo menos alguns setores editorais. No entanto, essa não é a realidade atual, e, portanto, para se estudar o produto livro é fundamental que editoras sejam levadas em consideração. Também por esse motivo, a entrega de conteúdo do produto livro por parte de editoras é que será objeto de estudo.

\subsection{Setorização editorial}

Segundo Thompson (2005, p. 6):

Um setor é um espaço estruturado de posições sociais; é um espaço estruturado de recursos e poder com suas formas próprias de competição e premiação. Mercados são importantes partes dos setores, mas setores são muito mais do que mercados; eles também são feitos de agentes e organizações e as relações entre eles, de redes e cadeias de suprimentos de 
diferentes tipos e quantidades de poder e recursos que são distribuídos de determinadas maneiras, de práticas específicas e formas de competição etc. ${ }^{7}$

Usualmente a indústria editorial de livros é dividida em diversos setores para fins de pesquisas de classe. No Reino Unido, por exemplo, são cinco os setores segundo a Publishers Association (2005): acadêmicos/profissionais, escolares/estudo de inglês, infantis, nãoficção/referência e ficção. No Brasil a indústria é dividida em quatro setores: didáticos, religiosos, obras gerais e científico-técnico e profissionais (FIPE, 2007). Ao responder a pesquisa setorial, cada editora se autoclassifica como pertencente a apenas um setor, mesmo que produza livros em diversos.

Para efeito da publicação de dados da indústria, essa classificação pode ser útil, no entanto, para fins da análise proposta nesta pesquisa é deficiente, pois não leva em conta os seguintes fatores:

a) Editoras não publicam necessariamente um só tipo de livro.

b) Existem diversos tipos de livros em cada setor, muito diferentes entre si, quer seja do ponto de vista da produção, da apresentação ou do consumo do conteúdo. Ou seja, os tipos de livros, e não os setores, são afetados de maneiras distintas pela digitalização e pela internet.

De acordo com Dubini (apud FURTADO, 2004) existem três maneiras de dividir por setor a indústria editorial. Em termos de características de seu produto e sua utilização (classificada por gênero), grupo de clientes que atinge (a que interesse a leitura satisfaz) e a tecnologia principal utilizada (papel ou eletrônica, por exemplo). A grande possibilidade de combinação dessas opções para definir a estratégia de uma empresa ajuda a explicar a heterogeneidade do setor.

Nesse sentido, apesar de ser apresentada como uma única indústria, as editoras possuem formas de produção e comercialização bastante diferenciadas por setor. Apesar de, em todos eles, a digitalização ter aumentado a produtividade, ela influencia de maneiras distintas na comercialização. A digitalização acentua as diferenças entre os setores, que vêm divergindo e

\footnotetext{
7 “A field is a structured space of social positions; it is a structured space of resources and power with its own forms of competition and reward. Markets are an important part of fields, but fields are much more than markets: they are also made up of agents and organizations and the relations between them, of networks and supply chains, of different kinds and quantities of power and resources that are distributed in certain ways, of specific practices and forms of competition, etc."
} 
migrando em diferentes velocidades. Os setores $\mathrm{STM}^{8}{ }^{8}$ Scientific, Technical and Medical, e acadêmico já são, em parte, digitais e vêm enfrentando grandes mudanças em seus modelos de negócio (MARTYNS, 2006). Para apresentarem consistência, estudos sobre a indústria editorial devem levar em conta esta setorização (FURTADO, 2004).

De acordo com Thompson (2005), existem oito formas de serem apresentados conteúdos escritos na indústria editorial: ${ }^{9}$

a) Dados: São compilações de números como preços de ações.

b) Informação: Conteúdo descritivo, como jurisprudência de tribunais.

- Conhecimento (quatro tipos):

c) Resultados discretos: Forma discursiva articulada que auxilia no entendimento do mundo, normalmente apresentado sob forma de artigos acadêmicos.

d) Conhecimento agregado: Acúmulo de resultados discretos em texto extenso sobre um determinado tópico ou tema. Normalmente apresentado sob a forma de obras de referência como dicionários e enciclopédias.

e) Conhecimento pedagógico: Forma de conhecimento que tem o objetivo pedagógico de apresentar a estudantes o conteúdo de um determinado campo de estudos. Habitualmente apresentado sob a forma de livros didáticos.

f) Argumentos sustentados: Forma de conhecimento que apresenta um argumento sustentado ou análise em um texto extenso. Normalmente são apresentados sob a forma de monografias ou livros.

- Narrativa (dois tipos - é a forma na qual o conteúdo é articulado como uma história extensa com começo, um enredo e um final)

g) Ficção

h) Não-ficção: Como em biografias ou livros que contam a história de algum acontecimento. Muitas vezes se confunde com a forma de argumento sustentado.

Para uma análise mais consistente, já que diversas editoras publicam mais de um tipo de livro, esta pesquisa não utilizará o conceito de classificação da pesquisa da FIPE (2007), e sim de seus produtos principais, os livros impressos.

\footnotetext{
${ }^{8}$ STM - Não existe setor correspondente a esse no mercado editorial brasileiro, sendo o mais próximo o CTP (científico-técnico e profissionais).

${ }^{9}$ Nesse caso, ao contrário de todos os outros ao longo do texto, indústria editorial é entendida no sentido amplo e não apenas a que publica livros.
} 
O produto livro didático impresso de ensino superior, que se encaixa na divisão “conhecimento pedagógico" será utilizado como objeto de estudo desta pesquisa. As razões para sua utilização são:

a) Produto utilizado em universidades com público jovem, normalmente mais afeito a mudanças tecnológicas.

b) Pelo fato do setor ser bastante sensível ao emprego de novas tecnologias. Segundo Thompson (2005), quanto mais elaborado o produto oferecido ao professor, incluindo material multimídia, maior a chance de adoção.

c) O livro se constitui, muito provavelmente, no principal material didático utilizado por professores universitários das diversas áreas de conhecimento (ROSA, 2007).

d) Apesar do número de estudantes matriculados nas universidades ter aumentado em $365 \%$ entre 1995 a 2005, de acordo com o senso MEC/INEP (2006), houve uma queda de $16 \%$ na venda de livros científico-técnico e profissional (FIPE, 2006), da qual fazem parte os livros didáticos de ensino superior.

e) É comum que editoras que publicam esse tipo de livro agreguem valor ao produto de diversas maneiras, como, por exemplo, na definição do tema, participando na elaboração dos conteúdos e na divulgação por meio de equipes de profissionais,

Por ser um negócio normalmente de altos volumes, o conteúdo deve ser bastante desenvolvido em conjunto com os autores e os custos de produção tendem a ser altos (THOMPSON, 2005, p. 28). É por isso que algumas das maiores editoras do mundo como Pearson, Oxford e Thomson publicam livros nesse setor.

Outra característica que diferencia esse setor de outros da indústria editorial é que ele funciona com o sistema de adoção. Nele o produto é divulgado para professores para que indiquem e seus estudantes o comprem (THOMPSON, 2005). Ou seja, os professores são os responsáveis pela escolha dos livros e da maneira como seu conteúdo é apresentado para os alunos.

Livros didáticos são escritos para e usados por professores e estudantes com o objetivo de ensinar e aprender (THOMPSON, 2005). Ou seja, apesar de qualquer livro utilizado para ensinar poder ser chamado de didático, essa definição restringe o campo de estudo àqueles produzidos com esse fim. 


\section{$2.4 \quad$ O livro eletrônico}

Em 1971, Michael Hart, fundador do Projeto Gutenberg, iniciou a digitalização de livros de domínio público. Estes foram os primeiros livros eletrônicos em termos de conteúdo (BURK, 2001; LOURENÇO, 2004). No entanto, somente a partir do primeiro boom da internet no final dos anos 1990 é que o livro eletrônico passa a ser pensado como um possível produto comercial (HERTHER, 2005).

A partir de 1999, novos modelos de negócio em torno do livro eletrônico passaram a ser testados. Em março de 2000, Stephen King, um dos autores de maior vendagem nos Estados Unidos, realizou a experiência de vender diretamente aos consumidores seu livro The Plant, à medida que o escrevia. Apesar das boas vendas iniciais, o projeto não foi para frente e o livro nem chegou a ser finalizado. Assim como esse, praticamente todos os negócios ligados à comercialização de livros eletrônicos mostraram-se inviáveis (HERTHER, 2005). No entanto, a partir de 2004, começaram a surgir alguns modelos de negócio com potencial para dar bons resultados. Segundo a pesquisadora, no ano de 2005 iniciou-se a segunda era do livro eletrônico. Ela se caracteriza por vendas baixas, taxas de crescimento entre $20 \%$ e $40 \%$, mas otimismo por parte da indústria para superar os obstáculos existentes para a viabilização de modelos de negócios com livros eletrônicos.

Livros eletrônicos são bastante distintos de livros impressos. Para realçar as diferenças foi elaborado o quadro 1 com as vantagens e desvantagens daquele em relação a este. ${ }^{10}$

\footnotetext{
10 A maior parte das vantagens e desvantagens pressupõe o livro eletrônico como virtual, ou seja consumido como arquivo sonoro ou digital.
} 
Quadro 1 - Vantagens e desvantagens do livro eletrônico sobre o impresso

\begin{tabular}{|c|c|}
\hline Vantagens & Autores \\
\hline $\begin{array}{l}\text { Facilidade de transporte, mobilidade, portabilidade. Em pequenos } \\
\text { dispositivos, pode-se armazenar grande quantidade de títulos }\end{array}$ & $\begin{array}{l}\text { KESTNER (2001a), GOMEZ } \\
\text { (2008), ANURADHA,USHA } \\
\text { (2006), HAGE (2005), BURK } \\
\text { (2001), RAO (2001), GUNTER } \\
\text { (2005), GIBSON; RUOTOLO } \\
\text { (2003), BUNELLE (2000), } \\
\text { TAYLOR (2006), MELLO } \\
\text { (2002) }\end{array}$ \\
\hline $\begin{array}{l}\text { Podem ser facilmente transformados em arquivos sonoros, oferecer } \\
\text { informações multimídia }\end{array}$ & $\begin{array}{l}\text { KLEEGE (2006), TAYLOR } \\
\text { (2006), ANURADHA,USHA } \\
(2006)\end{array}$ \\
\hline $\begin{array}{l}\text { Podem ser conectado por meio de hipertexto com outros materiais } \\
\text { ou textos de interesse, como dicionários }\end{array}$ & $\begin{array}{l}\text { GOMEZ (2008), } \\
\text { ANURADHA,USHA (2006), } \\
\text { BURK (2001), TAYLOR (2006), } \\
\text { BORGMAN (2007), BUNELLE } \\
(2000)\end{array}$ \\
\hline Podem ser atualizados rapidamente & KESTNER (2001), HAGE (2005) \\
\hline Podem ser vendidos por capítulos & $\begin{array}{l}\text { TAYLOR (2001a), TAYLOR } \\
(2006)\end{array}$ \\
\hline Podem-se buscar expressões ou palavras em todo o texto facilmente & $\begin{array}{l}\text { ANURADHA, USHA (2006), } \\
\text { BURK (2001), RAO (2001), } \\
\text { BUNELLE (2000), TAYLOR } \\
\text { (2006), MELLO (2002) }\end{array}$ \\
\hline Possibilidade de alterar o tamanho e o tipo das fontes & $\begin{array}{l}\text { ANURADHA,USHA (2006), } \\
\text { RAO (2005), BURK (2001), } \\
\text { BUNELLE (2000) }\end{array}$ \\
\hline $\begin{array}{l}\text { Possibilidade de acesso fácil via internet a uma grande oferta do } \\
\text { produto } 24 \text { horas por dia. Acesso conveniente e flexível }\end{array}$ & $\begin{array}{l}\text { ANURADHA,USHA (2006); } \\
\text { RAO (2005), BURK (2001); } \\
\text { HAGE (2005), GIBSON, } \\
\text { RUOTOLO (2003), MELLO } \\
\text { (2002) }\end{array}$ \\
\hline Não fica com aparência de envelhecido, não quebra & BURK (2001) \\
\hline São ecologicamente corretos, pois não consomem papel & BUNELLE (2000) \\
\hline As cópias são perfeitas & BORGMAN (2007) \\
\hline Desvantagens & Autores \\
\hline Poucos títulos disponíveis & RAO (2005) \\
\hline Possível dependência de determinados softwares de leitura & RAO (2005) \\
\hline $\begin{array}{l}\text { Um livro eletrônico pode utilizar o modelo de negócio de acesso } \\
\text { on-line. Nesse caso, o consumidor não tem posse do produto, como } \\
\text { sempre ocorre quando compra um livro físico. Isso pode ser um } \\
\text { problema no caso da editora fechar as portas ou o contrato de } \\
\text { direitos autorais se encerrar }\end{array}$ & RAO (2005) \\
\hline $\begin{array}{l}\text { Público leitor, em sua grande maioria, não tem interesse em ler } \\
\text { longos trechos em telas ou ouvi-los }\end{array}$ & BORGMAN (2007) \\
\hline
\end{tabular}

Atualmente já existem no mercado diversos modelos de negócio que procuram comercializar o livro eletrônico, aproveitando algumas das vantagens listadas no quadro acima. Venda e aluguel do conteúdo, na íntegra e fracionado, para consumo somente em telas, impresso ou 
sonoro, são algumas alternativas que diversas editoras vêm buscando para viabilizar novos caminhos. ${ }^{11} \mathrm{Na}$ realidade, qualquer editora pode fornecer livros eletrônicos já que o processo de produção de um livro é quase todo digital. Isso significa que, para uma editora transformar seu produto em livro eletrônico, basta convertê-lo para algum formato utilizado pelos consumidores.

Assim como livros em papel, a denominação "livro eletrônico" pode ter mais de um significado. Rao (2005) propõe quatro dimensões para se analisar livros eletrônicos:
a) Conteúdo - Refere-se à propriedade intelectual
b) Formato - Refere-se ao documento ou formato de arquivo
c) Leitor - Refere-se ao software
d) Aparelho de leitura - Refere-se ao aparelho portátil ou hardware de leitura

Mesmo quando se trabalha apenas com uma das quatro dimensões, no caso, conteúdo, ou mais precisamente, a apresentação deste, definir o que é livro eletrônico não é tarefa simples. Uma das razões para a dificuldade dessa definição é que no mundo digital, conteúdo e a mídia em que é armazenado são, muitas vezes, imprecisamente, considerados sinônimos (GALL, 2005; ANURADHA; USHA, 2006). Segundo Lynch (2001) livro eletrônico é um conjunto de bits que pode ser transportado por mídia eletrônica ou entregue via rede e desenhado para ser visto em uma combinação de software e hardware, mas existem independentemente dos mecanismos que podem ser usados para acessá-los ou lê-los. Gibson e Ruotolo (2003) definem o livro eletrônico como qualquer texto completo e eletrônico feito para ser lido em uma tela desde que não em um navegador da internet. Para Anuradha e Usha (2006), é um texto eletrônico que serve aos mesmos propósitos que um livro impresso e pode parecer fisicamente com ele. De acordo com Rao (2001), o livro eletrônico é um texto em formato digital a ser exibido em uma tela de computador ou lido em algum aparelho portátil. Para Gunter (2005) é qualquer sequência de texto do tamanho de uma monografia ou livro disponível em formato eletrônico.

A definição de livro eletrônico para esta pesquisa é mais ampla. Para que essa definição fique clara, é necessário apresentar um modelo de negócio que existe somente no Brasil, chamado Pasta do Professor. ${ }^{12}$ Nesse modelo, algumas das maiores editoras de livros didáticos de

\footnotetext{
${ }^{11}$ Uma lista com novos modelos de negócios esta disponível no Apêndice 4 desta pesquisa.

${ }^{12}$ Uma definição mais detalhada dessa iniciativa encontra-se no Apêndice 5 desta pesquisa.
} 
ensino superior, associadas da ABDR, disponibilizam arquivos digitais de seus livros para impressão em postos autorizados. Os livros podem ser impressos na íntegra ou em partes. Ou seja, inteiro ou em partes, é lido em material impresso. Pode-se argumentar que esse não seria um modelo de comercialização de livro eletrônico, pois, ao final, o consumidor tem um produto impresso. No entanto, em outros modelos de negócio (como aluguel ou venda do conteúdo em formato eletrônico), pode-se também imprimir o conteúdo e lê-lo no papel. Pode-se também, com um software adequado, ouvir um livro digital. Assim, a definição de livro eletrônico para esta pesquisa não leva em consideração como o leitor irá consumir, mas sim como o produto é disponibilizado pelas editoras.

- Livro eletrônico: É um livro digital em arquivo texto ou sonoro que pode ser:

a) Vendido (ou disponibilizado) na íntegra ou em partes.

b) Alugado (por acesso pago on-line por determinado período de tempo).

c) Vendido por capítulos gerados de arquivo digital, mas impressos para o consumidor em um ponto de venda (Pasta do Professor).

Nesse sentido, o importante não é como o livro será consumido (lido ou ouvido), mas sim como saiu da editora para ser comercializado.

\subsection{Adoção de inovação}

Segundo Rogers (1995), a adoção de uma inovação é um processo envolvendo indivíduos e grupos que decidem pela adoção como a melhor ação disponível. Tendo sido adotada uma inovação por indivíduos ou grupos, ela pode ou não se difundir. "Inovação é uma ideia, prática ou objeto que é percebida como nova por um indivíduo ou outra unidade de adoção." (ROGERS, 1995, p. 11).

De acordo com Rogers (1995), existem cinco características que podem ser percebidas por adotantes ou potenciais adotantes em uma inovação, que são:

a) Vantagem relativa: É o grau pelo qual uma inovação é percebida como melhor do que suas precursoras.

b) Compatibilidade: É o grau pelo qual uma inovação é percebida como sendo consistente com os valores existentes, experiências passadas e necessidades de potenciais adotantes. 
c) Complexidade: É o grau pelo qual uma inovação é percebida como difícil de se entender como utilizar.

d) Experimentação: É o grau pelo qual uma inovação pode ser experimentada por um determinado período.

e) Observalidade: É o grau pelo qual uma inovação é visível para outras pessoas.

Em relação aos tipos de decisão sobre o uso de uma inovação, Rogers (1995, p. 28-29) apresenta três:

a) Decisões opcionais: "São escolhas de adotar ou rejeitar uma inovação que são feitas por um indivíduo independentemente da decisão de outros membros do sistema."

b) Decisões coletivas: "São escolhas de adotar ou rejeitar uma inovação que são feitas por consenso entre membros de um sistema."

c) Decisões de autoridade: "São escolhas de adotar ou rejeitar uma inovação que são feitas por um número relativamente pequeno de indivíduos de um sistema que possuem poder, status ou conhecimento técnico. O indivíduo membro do sistema tem pouca ou nenhuma influência na decisão [...]."

No caso de livros didáticos de ensino superior, a decisão sobre o uso da inovação é do tipo "autoridade", pois quem define que livros serão lidos é uma autoridade, ou seja, o professor. Segundo Rogers (1995), nos casos em que a decisão é do tipo autoridade, é esta autoridade que deve ser pesquisada e não o usuário da inovação. Outro ponto destacado por Rogers (1995) sobre as decisões de autoridade é que essas, geralmente, têm maior velocidade de adoção. Caso professores decidam pela adoção de livros eletrônicos, eles provavelmente passarão a ser utilizados rapidamente.

O processo de adoção de inovações em tecnologia tem sido alvo de estudos a partir dos anos 1960, quando as organizações passaram a investir mais em sistemas computadorizados (PEREZ, 2006).

Moore e Benbasat (1991) embasaram-se na teoria de difusão de inovações de Rogers e desenvolveram um instrumento para medir as várias percepções que um indivíduo pode ter ao adotar uma inovação de tecnologia de informação. Os autores focaram seu instrumento nas características percebidas da inovação, pois concluíram que os diversos estudos que examinaram as características primárias de inovações mostraram-se inconsistentes. No 
entanto, ao contrário de Rogers, Moore e Benbasat (1991) basearam seu estudo nas características percebidas de uso de uma inovação tecnológica e não nas características percebidas de uma inovação em si (PEREZ, 2006). Partindo da teoria de Rogers e por meio de uma pesquisa robusta, chegaram a oito características que permitem predizer o comportamento dos indivíduos pela forma como são percebidas.

a) Vantagem relativa: Grau com o qual uma inovação é percebida como melhor que as precursoras.

b) Compatibilidade: Grau com o qual a inovação é percebida como consistente com valores existentes, necessidades e experiências passadas dos adotantes potenciais.

c) Experimentação: Grau com o qual uma inovação pode ser experimentada antes de sua adoção.

d) Facilidade de uso: Grau com o qual uma inovação é percebida como fácil de ser usada.

e) Imagem: Grau com o qual o uso de uma inovação é percebido para melhorar a imagem de um indivíduo.

f) Uso voluntário: O grau com o qual o uso da inovação é percebido como voluntário ou espontâneo.

g) Visibilidade: O grau com o qual uma inovação se torna visível para indivíduos ou grupos de uma organização.

h) Demonstração de resultados: Tangibilidade dos resultados pelo uso da inovação.

Livro eletrônico não é novidade no sentido do lapso de tempo entre sua criação e esta pesquisa. No entanto, ele pode ser considerado uma inovação, pois, por conta da digitalização de boa parte do conteúdo editorial, expansão da internet e da capacidade dos computadores, sua utilização prática só pôde ser discutida de alguns poucos anos para cá.

O instrumento de Moore e Benbasat (1991) vem sendo utilizado em diversos estudos, normalmente ligados à inovação tecnológica. Ele foi criado com intuito de "[...] medir as várias percepções que um indivíduo pode ter ao adotar uma inovação em tecnologia de informação"13 (MOORE; BENBASAT, 1991, p. 192). Alguns exemplos são Perez (2006), que estudou prontuários eletrônicos na área da saúde, Beckett (2007), que pesquisou a adoção de um novo software, e Illie et al. (2005) na área de tecnologia da comunicação. Por sua

\footnotetext{
13 "[...] to measure the various perceptions that an individual may have of adopting an information technology (IT) innovation."
} 
utilização frequente nas mais diversas áreas ligadas à tecnologia, o instrumento se mostra adequado a esta pesquisa.

Os modelos que tratam sobre adoção de inovação estão direcionados para a percepção do usuário ou das empresas. De acordo com os objetivos desta pesquisa, a teoria da difusão de inovação se encaixa e o instrumento de Moore e Benbasat (1991), por estar validado, serve de base como modelo para a pesquisa de campo.

De acordo com Hage (2005), apesar de existirem muitos estudos sobre aceitação de uma nova tecnologia e inovações que se difundiram, existem poucos que focam nas que não atingiram seu potencial. Livro eletrônico é, possivelmente, uma delas. 


\section{METODOLOGIA DA PESQUISA}

De acordo com Zikmund (2003), existem três tipos de pesquisa em termos de função:

a) Exploratória: Quando se pesquisa para encontrar a dimensão do problema. Auxilia coletando informações necessárias para que futuras pesquisas cheguem a evidências conclusivas.

b) Causal: Seu objetivo principal é identificar relação de causa e efeito entre variáveis.

c) Descritiva: Tem como objetivo principal descrever características de uma população ou fenômeno, muitas vezes de maneira segmentada.

Para Collis e Hussey (2005), pesquisas podem ser classificadas em relação ao método adotado como:

a) Qualitativa: Mais subjetiva, interpretativa e humanista.

b) Quantitativa: Mais objetiva, focada na mensuração dos fenômenos.

Segundo Sampieri et al. (2006, p. 101), estudos descritivos “[...] medem, avaliam ou coletam dados sobre diversos aspectos, dimensões ou componentes do fenômeno a ser pesquisado." Os mesmos autores (2006, p. 5) descrevem o enfoque quantitativo como aquele que "[...] utiliza a coleta e a análise de dados para responder às questões de pesquisa e testar hipóteses estabelecidas previamente [...]."

De acordo com Pinsonneault e Kramer (1993), pesquisas survey possuem três características distintas: 1) Devem produzir uma descrição quantitativa de algum(ns) aspecto(s) da população estudada, 2) o principal caminho para se conseguir informações é realizando perguntas estruturadas e pré-definidas e 3) normalmente as informações coletadas são de apenas uma fração da população, a amostra.

Uma survey descritiva é utilizada quando se quer descobrir que situações, eventos, atitudes ou opiniões estão ocorrendo em uma população (PINSONNEAULT; KRAMER, 1993). O interesse do pesquisador é descrever e fazer uma comparação entre os resultados de duas populações. Segundo os autores, o método survey é apropriado quando a intenção do pesquisador é saber "o que está acontecendo" ou "como e por que isso está acontecendo" e o objeto de interesse ocorre no presente ou passado recente. 
Este é um estudo descritivo de enfoque quantitativo que utilizará o método survey.

Apesar de esse estudo ser de natureza quantitativa, foram incluídas perguntas abertas para uma abordagem qualitativa e realizadas algumas entrevistas. Esse modelo de estudo, no qual uma enfoque prevalece sobre o outro é chamado de "modelo de enfoque dominante" (SAMPIERI et al., 2006). De acordo com Pinsonneault e Kramer (1993), utilizar mais de um método para coleta de dados é interessante, pois se tem uma abrangência e riqueza maior do fenômeno de interesse. Esse procedimento é relevante por conta do pequeno número de pesquisas na área e para enriquecer a coleta e a análise.

Foi utilizado o instrumento de Moore e Benbasat (1991) elaborado para medir as percepções de indivíduos sobre as características de uso de uma inovação tecnológica com adaptações.

\subsection{Método de pesquisa}

O método de pesquisa utilizado foi a survey. Foram enviados questionários a todos os professores de graduação da Faculdade de Administração da FEA-USP, Faculdade de Economia e Administração da Universidade de São Paulo, da cidade de São Paulo e da Faculdade de Administração da Universidade Mackenzie, unidades São Paulo e Tamboré. Também foram enviados questionários a profissionais de editoras de livros didáticos de ensino superior de administração com objetivo de conhecer sua percepção sobre a adoção de livros eletrônicos nas faculdades.

Segundo Moore e Benbasat (1991), a intenção do desenvolvimento do instrumento foi para que ele pudesse servir para uma variedade de usos, mesmo que com eventuais adaptações. Rogers (2003) afirma que novos atributos de inovações podem surgir e, portanto, mesmo utilizando-se escalas, estas podem ser adaptadas para situações particulares.

Em relação aos oito fatores destacados por Moore e Benbasat (1991) o pesquisador entendeu que são todos relevantes da maneira como foram listados, pois foram desenvolvidos para uma variedade de usos. A proposta para validação foi feita com todos os fatores sem adaptações. 
Por outro lado, o caso pesquisado necessita de adaptações por conta da especificidade da inovação, já que livros eletrônicos, entendidos como consumo de conteúdo, têm diferenças importantes em relação a inovações como estações pessoais de trabalho (utilizada por Moore e Benbasat (1991) na criação do instrumento). Em primeiro lugar, livros eletrônicos não são um hardware e sim necessitam de algum tipo de hardware para serem consumidos. Em segundo, o conteúdo de um livro é uno, mas pode ser fragmentado em partes (trechos, páginas, capítulos). Terceiro, a oferta de "modelos", que no caso são chamados de títulos diferentes, chega aos milhões. E, finalmente, o custo é fator fundamental, pois o exato mesmo produto (em termos de conteúdo) é oferecido de outra maneira (como livro impresso), fazendo com que a comparação seja necessária. Desta maneira o pesquisador propôs algumas novas variáveis para a serem validadas.

Foi solicitado a um profissional do mercado com experiência tanto no setor de livros didáticos de ensino superior quanto como professor universitário que avaliasse o modelo de pesquisa e os questionários para confirmar a validade destes. Ele também analisou a lógica e clareza do texto. Após essa análise, foi realizado um teste de face, que, segundo Zikmund (2003), pode ser utilizado para dar validade aos critérios do pesquisador. Em seguida um teste piloto para comprovar a clareza das questões.

O instrumento de Moore e Benbasat (1991) procura medir a percepção do uso de uma inovação tecnológica. No entanto, no caso da inovação não estar sendo plenamente utilizada, ele é considerado válido para medir a percepção de uso de um potencial adotante, desde que este conheça o produto oferecido.

Algumas perguntas do questionário foram feitas no condicional, pois parte-se do princípio de que livros eletrônicos não são utilizados no dia a dia em sala de aula na maior parte dos casos. Esse pressuposto é baseado em pesquisa da CBL (Produção e vendas do setor editorial brasileiro), que não afere a comercialização do produto por considerá-la irrelevante (FIPE, 2007). 


\subsection{Definição do universo de pesquisa}

\subsubsection{Professores de ensino superior}

O universo de pesquisa é composto pelos professores de graduação das faculdades de administração da FEA-USP de São Paulo e da Universidade Mackenzie, unidades São Paulo e Tamboré.

Foram escolhidas faculdades de administração por ser esse um segmento, juntamente com direito e medicina, que tem maior volume de vendas de livros didáticos universitários.

A FEA-USP e o Mackenzie foram escolhidos pelos seguintes motivos:

- Uma instituição pública e uma privada.

- Instituições que contam com o sistema Pasta do Professor em suas dependências.

- Facilidade de acesso.

O professor é quem indica os livros didáticos a serem lidos pelos estudantes. Ao contrário de outros setores da indústria, como o de obras gerais, nos quais o consumidor tem liberdade de escolha, o estudante, na maior parte dos casos, não escolhe o produto. É um processo parecido com o da relação médico-paciente. Usualmente o paciente toma o remédio que lhe foi indicado pelo médico. É por esse motivo que a indústria farmacêutica apresenta suas drogas aos médicos e que as editoras de livros didáticos fazem divulgação de seus produtos para os professores. É por essa razão que o questionário foi aplicado a professores.

Foram selecionados para a pesquisa professores das duas instituições que haviam dado aulas para a graduação durante 2008. O total de professores do Mackenzie é de 200 e da USP de 71.

\subsubsection{Profissionais de editoras}

O universo de pesquisa é composto de todos os profissionais das áreas comercial e editorial, de nível gerencial ou superior, de editoras de livros didáticos universitários da área de administração. 
O setor editorial de livros didáticos de ensino superior é o mais afetado pela cópia não autorizada de seus conteúdos. Por conta desse problema foi fundada uma associação chamada ABDR, que busca impedir a cópia não autorizada. São membros dessa associação 96 editoras, sendo 15 delas produtoras de livros didáticos de ensino superior de administração. Outras 3 editoras não associadas também publicam livros didáticos de ensino superior de administração.

Livros didáticos são aqueles produzidos para serem utilizados por professores e estudantes para ensinar e aprender (THOMPSON, 2005). Como área de administração entende-se aquelas que publicam livros que abrangem matérias em algum dos seguintes campos: marketing, economia, métodos quantitativos, finanças, administração geral, operações e recursos humanos.

Os critérios utilizados para definição de editora de livros didáticos de ensino superior foram:

a) Solicitação para a ABDR da lista de editoras que, segundo a Associação, tinham em seu catálogo livros didáticos de ensino superior em administração. Foram listadas 25 editoras.

b) Análise por parte do pesquisador a fim de verificar se todas realmente tinham esse perfil. Dez foram descartadas.

c) Análise em sites de livrarias virtuais (Livraria Cultura e Saraiva) da lista de livros publicados na área de administração. Foram encontradas mais três editoras. ${ }^{14}$

Não é relevante para esta pesquisa se a editora pesquisada publica também livros de outros setores.

Definido o universo das editoras, cada uma delas foi contatada para identificar e conseguir com que profissionais com perfil adequado respondessem ao questionário. Foram entrevistados profissionais das áreas comercial e editorial, por serem ligadas diretamente ao conteúdo e à comercialização dos livros.

\footnotetext{
${ }^{14}$ A lista completa das editoras analisadas encontra-se no Apêndice 6.
} 
A opinião dos profissionais das editoras é relevante, pois há indícios de que as gravadoras, no caso da indústria fonográfica, estão enfrentando dificuldades por conta de não conhecerem seu público e não atentarem a mudanças relativas à digitalização do produto e a disseminação da internet. E editoras, conforme fundamentado na seção 2.2, são importantes elos da cadeia comercial do livro.

\subsection{Amostra}

A amostra buscada foi não probabilística de indivíduos voluntários.

Com a impossibilidade prática de serem pesquisados todos os professores de administração das faculdades brasileiras, foram trabalhadas duas faculdades escolhidas por conveniência: Faculdade de Administração da FEA-USP, em São Paulo, e Faculdade de Administração do Mackenzie, unidades São Paulo e Tamboré.

O número de professores que ministraram aulas no curso de graduação em administração nas duas faculdades é de 271.

O total de editoras que publicam livros didáticos de administração é 18.

Pesquisas divergem sobre a taxa média de retorno de questionários enviados pela internet (intenção deste estudo). De acordo com Weible e Wallace (1998), essa taxa é de 26\%, por outro lado, Hipólito et al. (1996) afirmam que a taxa seria de 8,6\%.

No item seguinte é detalhada a estratégia do pesquisador para conseguir um número adequado de respondentes.

\subsection{Estratégia de coleta de dados}

A coleta de dados foi realizada de duas maneiras: 
a) Dados secundários oriundos de livros e artigos científicos primordialmente. No entanto, por ser um campo de estudo novo e dinâmico sobre o qual poucas pesquisas acadêmicas vêm sendo realizadas, foram utilizados artigos em jornais e revistas não acadêmicos, bem como pesquisas de mercado e sites da internet.

b) Questionários estruturados com perguntas abertas aplicados por meio de mensagens eletrônicas.

No caso dos professores, foi enviada a primeira mensagem eletrônica em meados de novembro de 2008. Após duas semanas, uma segunda foi enviada aos que não haviam respondido. Dessa maneira, foi conseguido um número adequado de respondentes do Mackenzie. No caso dos professores da USP, para aumentar o número de respondentes, além das mensagens, o pesquisador conversou com alguns deles por telefone, com secretarias, além de fazer uma visita às suas salas.

No caso dos profissionais de editoras, o pesquisador entrou em contato telefônico com cada uma das empresas. Em alguns casos, já tinha conhecimento pessoal do provável respondente, em outros identificou-os. Foram conseguidas respostas de profissionais de 17 das 18 empresas listadas.

As fontes de pesquisa foram confrontadas para verificação de contradições ou possíveis problemas relacionados à posição e/ou atuação dos entrevistados.

\subsection{Escalas de mensuração}

Segundo Zikmund (2003), existem quatro tipos de escala: nominal, ordinal, intervalar e razão. Este estudo fez uso de uma escala ordinal de cinco pontos, variando de concordo totalmente a discordo totalmente.

A escala utilizada foi a de Likert que, segundo Mattar (1996) permite medir a intensidade de discordâncias e concordâncias. De acordo com Zikmund (2003) a escala de Likert serve para 
medir o quanto o respondente concorda ou discorda de uma determinada afirmação que varia de muito positiva a muito negativa em relação a uma atitude ou sentimento.

Outro motivo para a utilização desta escala é o fato dela ter sido utilizada por Moore e Benbasat (1991) em seu instrumento.

\subsubsection{Questionário para professores}

Foram elaboradas 41 perguntas baseadas no instrumento de Moore e Benbasat (1991) e formuladas mais 5 pelo pesquisador, sendo assim distribuídas:

a) Vantagem relativa - oito perguntas baseadas no instrumento de Moore e Benbasat (1991), duas formuladas pelo pesquisador.

b) Compatibilidade - quatro perguntas baseadas no instrumento.

c) Experimentação - sete perguntas baseadas no instrumento, uma formulada pelo pesquisador.

d) Facilidade de uso - seis perguntas baseadas no instrumento, duas formuladas pelo pesquisador.

e) Imagem - quatro perguntas baseadas no instrumento.

f) Uso voluntário - quatro perguntas baseadas no instrumento.

g) Visibilidade - quatro perguntas baseadas no instrumento.

h) Demonstração de resultados - quatro perguntas baseadas no instrumento.

O produto a ser analisado é o livro eletrônico como possível substituto do livro didático impresso de ensino superior. Nesse ponto existem duas observações importantes para que se possa entender a intenção do pesquisador ao utilizar esse instrumento:

a) Livros didáticos de ensino superior funcionam no sistema de adoção (THOMPSON, 2005). Nesse sistema, o professor recebe (ou compra) amostras de livros de sua matéria para possível indicação a seus alunos em sala de aula. O livro didático pode ser indicado integralmente ou em partes (capítulos). As editoras desse setor investem grandes recursos na divulgação de seus produtos (THOMPSON, 2005). Ou seja, para esta pesquisa, o relevante não é pesquisar as características percebidas da inovação pelo consumidor final (o estudante), e sim como essas características são percebidas pelo professor. 
b) O meio eletrônico não é uma novidade para professores. No entanto, livros eletrônicos, apesar de existirem a décadas, são pouco utilizados (BORGMAN, 2007).

Algumas adaptações foram realizadas nas variáveis do instrumento por conta da especificidade do produto a ser pesquisado. Foram incluídas nos questionários perguntas relativas a preço, facilidade de utilização pelos alunos, invenção de novos hardwares, possibilidade de comercialização fragmentada e disponibilidade de títulos em formato eletrônico. A intenção era de que essas variáveis fossem validadas como relativas a uma das oito características apresentadas por Moore e Benbasat (1991).

a) Preço: Uma das razões indicadas para queda de vendas de livros didáticos impressos de ensino superior no mercado americano é o seu alto preço (THOMPSON, 2005). Nos Estados Unidos, uma das soluções encontradas pelos alunos é o comércio de livros usados. No Brasil, segundo estudos da consultoria Franceschini (2002), o alto preço também é um dos possíveis problemas. No entanto a solução encontrada pelos alunos tem sido as cópias não autorizadas realizadas por processo analógico, a reprografia. Existem indicações de que livros eletrônicos podem ser mais baratos que livros impressos (GOMEZ, 2008), por conta da economia de custos em papel, gráfica e estoque. Portanto, essa é uma variável relevante que será levada em conta no fator vantagem relativa.

b) Facilidade de utilização pelos alunos: Como esta pesquisa não é realizada com o adotante da inovação, e sim com aquele que indica sua utilização, é importante que este tenha em mente fatores ligados ao público consumidor. E por ter um perfil distinto do usuário da inovação, o professor pode ter uma visão diferente em relação a ela. Segundo Gomez (2008), qualquer pessoa com menos de 30 anos já é bem acostumada com o estímulo digital. As crianças de hoje, que cresceram com a internet e com o mundo inteiro à disposição ao alcance de um mouse, tem cada vez menos familiaridade com livros e outras fontes de informação escritas. Kestner (2001b) e Herther (2005) acreditam que as novas gerações, que têm crescido em grande contato com telas de computadores, não terão grandes problemas com a leitura de livros eletrônicos. Formas digitais de informação são vistas como parte natural das vidas da nova geração (KALLIAREKOS et al. 2005). Chartier (1998) destaca que muitos leitores já não passam mais pela leitura em papel. O público que cresceu em contato constante com computadores pode não gostar de ter uma luz sob sua cabeça e preferir a luz emitida por um aparelho eletrônico para leitura (QUINT, 2008). Apesar do conceito de livro 
eletrônico não envolver, necessariamente, o seu consumo em meio digital, essa é uma possibilidade real, importante e que pode aumentar o interesse pelo produto. Essa variável fará parte do fator facilidade de uso.

c) Invenção de novos hardwares de leitura: Boa parte dos leitores de livros não se sente confortável com a leitura em formato digital. Os hardwares para leitura de livros eletrônicos têm por objetivo facilitar a sua leitura. A entrada no mercado de novas mídias para a leitura de livros (ex. Sony E-Reader e Amazon Kindle) pode levar mais consumidores de livros impressos a se interessarem por leitura em meio digital. Segundo Martyns (2006), as indústrias de tecnologia estão se esforçando para criar a mídia perfeita para a leitura de livros eletrônicos. Apesar do conceito de livro eletrônico não envolver, necessariamente, o seu consumo em meio digital, essa é uma possibilidade real, importante e que pode aumentar o interesse pelo produto. Portanto, criar uma alternativa mais confortável para esse consumo é um fator que deve ser estudado. Essa variável será levada em conta no fator facilidade de uso.

d) Possibilidade de comercialização fragmentada: Rosa (2007) afirma que hoje dificilmente os professores podem se limitar a indicar apenas um livro didático por curso. Não há mais "autores definitivos", pois o conhecimento se fragmentou e as fontes de informação são muito numerosas. Martyns (2006) levanta a hipótese de que, com o aumento da especialização no ensino superior, os estudantes relutam em comprar livros didáticos dos quais usarão apenas parte do conteúdo. Como a quantidade de conteúdo disponível cresceu muito, apesar dos livros didáticos terem ficado maiores, só uma pequena parte deles acaba sendo usada nas salas de aulas. Por esse motivo, diversas editoras têm procurado novos modelos de negócios (KESTNER, 2001b). A possibilidade de um livro eletrônico ser vendido facilmente de maneira fragmentada, ao contrário do impresso, será levada em conta no fator vantagem relativa.

e) Pequena disponibilidade de títulos em formato eletrônico: Poucas editoras disponibilizam seus títulos em formato eletrônico (GOMEZ, 2008; ANURADHA; USHA, 2006). Existe uma real dificuldade em se indicar livros eletrônicos, por mais vantagens que ele possa vir a ter, se o conteúdo desejado não estiver disponível. Esta variável será levada em conta no fator experimentação. 


\subsubsection{Questionário para profissionais de editoras}

Foram elaboradas 41 perguntas baseadas no instrumento de Moore e Benbasat (1991) e formuladas mais 5 pelo pesquisador, sendo assim distribuídas:

a) Vantagem relativa - oito perguntas baseadas no instrumento de Moore e Benbasat (1991), duas formuladas pelo pesquisador.

b) Compatibilidade - quatro perguntas baseadas no instrumento.

c) Experimentação - sete perguntas baseadas no instrumento, uma formulada pelo pesquisador.

d) Facilidade de uso - seis perguntas baseadas no instrumento, duas formuladas pelo pesquisador.

e) Imagem - quatro perguntas baseadas no instrumento.

f) Uso voluntário - quatro perguntas baseadas no instrumento.

g) Visibilidade - quatro perguntas baseadas no instrumento.

h) Demonstração de resultados - quatro perguntas baseadas no instrumento.

Apesar do instrumento de Moore e Benbasat (1991) ter sido idealizado para medir as características percebidas do uso da inovação pelos seus potenciais adotantes, nesta pesquisa decidiu-se também utilizá-lo com os profissionais de editoras de livros didáticos de ensino superior. A razão é que dessa maneira é possível identificar as diferenças entre as características percebidas pelos professores e pelos profissionais de editoras. Assim, o questionário para os dois grupos é essencialmente o mesmo.

Conhecer a percepção dos profissionais do mercado editorial sobre as opiniões dos professores é relevante, pois, por conta da falta de conhecimento de seu público, as gravadoras vêm enfrentando dificuldades com a digitalização e disseminação da internet (KUSEK; LEONHARD, 2005). Por não acreditar em uma mudança no comportamento do consumidor com o advento das novas tecnologias, as gravadoras não criaram novos modelos de negócios. A Apple criou o Ipod e, atualmente, está mais bem posicionada na indústria fonográfica.

Existe, no entanto, um fator que deve ser levado em conta nos questionários para profissionais da indústria que não envolve a percepção dos professores, que são as cópias não autorizadas: 
- Cópias não-autorizadas passam a ser uma possível fonte de preocupações com o advento da distribuição digital (RAO, 2005). Uma vez colocados na rede, não existe um mecanismo confiável para impedir o primeiro usuário a redistribuir quantas cópias de um arquivo desejar (QUINT, 2008). Copiar conteúdo eletrônico é mais simples e barato do que reproduzir conteúdo impresso. Segundo Hage (2005), boa parte das editoras comerciais será reticente em oferecer seus produtos de forma digital até que se desenvolva uma proteção a seus direitos autorais. No entanto, mesmo codificações sofisticadas podem ser abertas (SHAVER, 2003; LIEBOWITZ, 2002). Produtos digitais não se tornam "usados" ou acabam quando consumidos e podem ser copiados sem custo algum, sendo que dificilmente se encontra o original. Produtos que têm essa característica são muitas vezes chamados de "consumo não rivalizável” (LIEBOWITZ, 2002). Esse pode não ser um grande problema para editoras de obras gerais, cujo público é disperso. No caso das editoras de livros didáticos de ensino superior, a indicação de um professor normalmente é para uma classe, cujos integrantes têm contato entre si. A compra e eventual distribuição de apenas uma cópia por toda a classe é um cenário provável. Alguns modelos de negócio preveem esse comportamento e procuram coibi-lo com a utilização de formato proprietário (ex. Kindle) ou realiza a entrega do conteúdo digital já impresso em pontos autorizados (Pasta do Professor). Segundo Taylor (2006), estudantes tendem a ser mais acostumados a computadores, em estreito contato com seus colegas que necessitam dos mesmos textos e com pouco dinheiro. Consequentemente, existe um alto risco de serem feitas cópias não-autorizadas.

De acordo com dados da consultoria Franceschini (2002), cerca de 10 milhões de livros são copiados por ano sem autorização dos detentores de direitos autorais. A maior parte de livros universitários. O temor das editoras é que esse número aumente em modelos de negócio com livros eletrônicos.

Apesar dessa variável não poder ser encaixada em nenhum dos fatores apresentados por Moore e Benbasat (1991), por sua relevância ela deve ser considerada e pesquisada. 


\subsubsection{Validação e aplicação dos questionários}

Os questionários foram validados em três etapas de acordo com o sugerido por Zikmund (2003):

Etapa 1 - Especialista no mercado editorial e que seja ou tenha sido professor universitário.

O estudo foi lido na íntegra por um profissional do mercado que é professor titular aposentado de história. ${ }^{15}$ Os aspectos de lógica e clareza não sofreram reparos.

Em relação ao questionário, todos os fatores foram considerados válidos. As seguintes perguntas foram consideradas repetitivas e, portanto, retiradas conforme proposta deste estudo:

- Vantagem relativa - professores

Indicar livros eletrônicos faria com que o meu trabalho fosse realizado mais facilmente.

Indicar livros eletrônicos melhoraria minha performance no trabalho.

De maneira geral indicar livros eletrônicos seria vantajoso para o meu trabalho.

- Vantagem relativa - profissionais

Indicar livros eletrônicos faria com que o trabalho dos professores fosse realizado mais facilmente.

Indicar livros eletrônicos melhoraria a performance do trabalho dos professores.

De maneira geral, indicar livros eletrônicos seria vantajoso para o trabalho dos professores.

- Compatibilidade - professores

Indicar livros eletrônicos seria totalmente compatível com a minha situação atual.

$\mathrm{Eu}$ acredito que indicar livros eletrônicos se encaixaria bem na maneira como eu gosto de trabalhar.

- Compatibilidade - profissionais

Indicar livros eletrônicos seria totalmente compatível com a situação atual dos professores.

$\mathrm{Eu}$ acredito que indicar livros eletrônicos se encaixaria bem na maneira como os professores gostam de trabalhar.

- Experimentação - professores

Antes de decidir pela indicação de um livro eletrônico, terei oportunidade de testá-lo.

\footnotetext{
${ }^{15}$ Jaime Pinsky, diretor editorial da Editora Contexto, professor doutor pela USP e titular aposentado de história pela Unicamp.
} 
Não tive que fazer muito esforço para testar o livro eletrônico.

- Experimentação - profissionais

Os professores têm possibilidade de testar o livro eletrônico antes de indicá-lo.

Os professores não têm que fazer muito esforço para testar o uso do livro eletrônico.

- Imagem - professores

Indicar livros eletrônicos é um símbolo de status na academia.

- Imagem - profissionais

Indicar livros eletrônicos é um símbolo de status na academia.

A pergunta abaixo foi eliminada do fator facilidade de uso por ter sido considerada sem sentido:

- Professores:

Utilizar livros eletrônicos exigiria muito esforço mental de meus alunos.

- Profissionais:

Os professores consideram que a utilização de livros eletrônicos exigiria muito esforço mental de seus alunos.

Etapa 2 - Teste de face

Segundo Zikmund (2003, p. 302), “[...] validade de face refere-se à concordância subjetiva de profissionais de que uma escala sob o ponto de vista lógico reflete cuidadosamente o que se propõe a medir". ${ }^{16} \mathrm{O}$ teste de face é utilizado para atestar essa validade.

No teste de face, os fatores e as variáveis que não foram eliminados na avaliação do especialista foram submetidos à avaliação de três professores universitários. ${ }^{17}$ Os fatores e as variáveis rejeitados por qualquer um deles foram eliminados da pesquisa.

Todas as variáveis retiradas de um dos questionários fizeram com que sua equivalente fosse retirada do outro. Nenhum fator foi retirado.

\footnotetext{
16 "Face validity refers to the subjective agreement among professionals that a scale logically appears to reflect accurately what it purposes to measure."

${ }^{17}$ Os nomes e minicurrículos dos especialistas encontram-se no Apêndice 8.
} 
- Especialista 1

Para esse especialista todas as variáveis foram consideradas pertinentes, nada devendo ser acrescentado ou retirado.

\section{- Especialista 2}

As seguintes variáveis foram consideradas repetitivas e, portanto, retiradas:

- Compatibilidade - Professores

Indicar livros eletrônicos seria compatível com todos os aspectos do meu trabalho.

- Compatibilidade - Profissionais

Indicar livros eletrônicos seria compatível com todos os aspectos do trabalho dos professores.

- Facilidade de uso - Professores

Eu acredito que seria fácil para meus alunos conseguirem fazer com livros eletrônicos o que eles quisessem.

De maneira geral, acredito que seria fácil para meus alunos utilizarem livros eletrônicos.

- Facilidade de uso - Profissionais

Os professores acreditam que seus alunos conseguiriam facilmente fazer com livros eletrônicos aquilo que quisessem.

De maneira geral, os professores consideram que seria fácil para seus alunos utilizarem livros eletrônicos.

- Uso voluntário - Professores

Meus chefes não me obrigam a indicar livros eletrônicos.

- Uso voluntário - Profissionais

Os chefes dos professores não os obrigam a indicar livros eletrônicos.

- Visibilidade - Professores

A indicação de livros eletrônicos não é muito comum na faculdade.

- Visibilidade - Profissionais

A indicação de livros eletrônicos não é muito comum na faculdade.

- Demonstração de resultados - Professores

Eu teria dificuldades em explicar por que indicar livros eletrônicos poderia ou não ser benéfico.

- Demonstração de resultados - Profissionais

Os professores teriam dificuldade em explicar por que indicar livros eletrônicos poderia ou não ser benéfico. 
- Especialista 3

- Vantagem relativa - Professores

Por conta da imprecisão da linguagem, a pergunta:

Utilizar livros eletrônicos faria com que o conteúdo da matéria fosse passado mais rapidamente.

Foi alterada para:

Utilizar livros eletrônicos faria com que os alunos tivessem acesso mais rápido à bibliografia do curso.

- Vantagem relativa - Profissionais

Por conta da imprecisão da linguagem, a pergunta:

Utilizar livros eletrônicos faria com que os professores conseguissem passar o conteúdo da matéria mais rapidamente.

Foi alterada para:

Os professores consideram que utilizar livros eletrônicos faria com que os alunos tivessem acesso mais rápido à bibliografia do curso.

As seguintes perguntas foram consideradas imprecisas e, portanto, retiradas:

- Vantagem relativa - Professores

Indicar a utilização de livros eletrônicos possibilitaria uma melhora na qualidade do meu trabalho.

- Vantagem relativa - Profissionais

Indicar a utilização de livros eletrônicos possibilitaria uma melhora na qualidade do trabalho dos professores.

- Imagem - Professores

Professores que indicassem livros eletrônicos seriam mais conhecidos.

- Imagem - Profissionais:

Professores que indicassem livros eletrônicos seriam mais conhecidos.

Além da avaliação sobre a pertinência das variáveis e fatores, nesta etapa, os profissionais foram solicitados a comentar sobre tamanho, linguagem e instruções do questionário. Os três pontos foram considerados adequados conforme apresentados. 
Etapa 3 - Teste piloto

De acordo com Zikmund (2003), o teste piloto auxilia o pesquisador a determinar se os respondentes têm alguma dificuldade em entender o questionário e se existem perguntas ambíguas ou enviesadas. Essa etapa foi realizada para dar maior clareza e qualidade ao questionário.

Nessa etapa, o questionário, já em seu formato final, foi aplicado a três colegas da pósgraduação, cinco profissionais do mercado editorial e cinco professores universitários (com titulação mínima de doutorado) para eventuais ajustes finais.

As sugestões de mudança que foram acatadas nessa etapa foram:

- Tornar todas as respostas obrigatórias.

- A definição de livro eletrônico sofreu leve modificação, sendo apresentada em tópicos para facilitar a leitura.

- Algumas pequenas mudanças no texto para simplificar a linguagem.

Tanto para o especialista quanto no teste de face, as perguntas foram apresentadas conforme constam no Apêndice 1. No teste piloto e na aplicação do questionário, as perguntas que incluem a escala foram apresentadas conforme Apêndice 2, ou seja, como viriam a ser aplicadas ao público-alvo.

\subsection{Técnicas de tratamento e análise dos dados}

Parte dos dados obtidos foi analisada de maneira qualitativa para se obter mais profundidade de análise. Em relação às afirmações nas quais se utilizou a escala Likert, foi realizada uma análise para determinar a natureza dos dados obtidos. Nesse caso, como a curtose e a assimetria foram consideradas estatisticamente iguais a zero, concluiu-se que a distribuição é normal. Como a variância de cada uma das variáveis não ultrapassa em três vezes a das outras, concluiu-se que os dados são independentes. 
Sendo assim, foi possível realizar uma análise de variância, que foi o instrumento estatístico utilizado.

\subsection{Modelo teórico-conceitual da pesquisa}

O modelo teórico conceitual é apresentado na Ilustração 2:

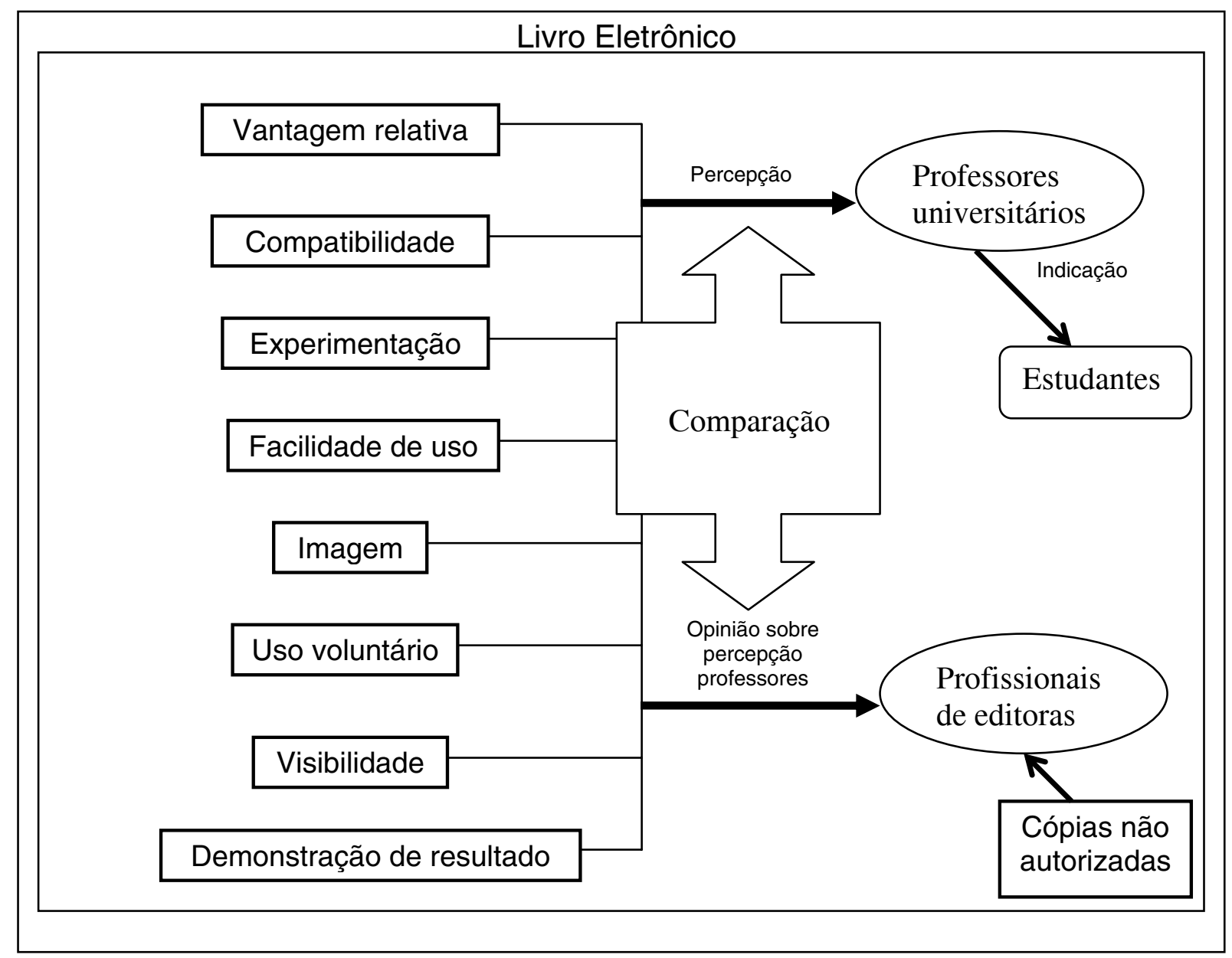

Ilustração 2 - Modelo teórico-conceitual

O instrumento de Moore e Benbasat (1991) foi escolhido por ser o mais adequado a esta pesquisa. Os fatores foram submetidos à avaliação do especialista profissional e professor, e também ao teste de face. Todos foram considerados relevantes. A decisão sobre a aplicação dos questionários aos professores seguiu a orientação de Rogers (1995) sobre decisões de 
autoridade. A aplicação do questionário adaptado aos profissionais de editoras foi decidida pelo pesquisador por serem elo importante na cadeia produtiva do livro.

Cópias não-autorizadas foram incluídas no modelo por serem fator importante de preocupação para profissionais de editoras em relação à viabilização de modelos de negócios ligados à oferta de livros eletrônicos. Essa não é uma característica relevante para professores universitários.

\subsection{Limitações da pesquisa}

A falta de estudos anteriores que liguem digitalização, internet e o mercado de livros, fez com que o autor desenvolvesse um método de estudo novo, agrupando outros métodos e teorias já consagrados. Por ter sido utilizado pela primeira vez, existe uma limitação do seu alcance.

Pela natureza do estudo, suas conclusões não podem ser utilizadas para todos os setores da indústria editorial.

Foi pesquisada somente uma área do conhecimento, administração. Apesar de dar indícios de como devem se comportar outras áreas em relação ao tema, as conclusões não podem ser generalizadas.

A amostra de profissionais de editoras, pela própria característica do trabalho, foi pequena, o que pode ter gerado vieses. Também no caso dos professores da USP, apesar do percentual elevado de respostas obtidas, o universo considerado era limitado, o que gerou uma pequena amostra.

Não se pesquisou se livros, em qualquer formato, continuarão sendo importantes para o ensino ou se outras fontes de transmissão de conteúdo o substituirão. Se livros estiverem deixando de ser importantes para a educação, a discussão sobre a entrega de seu conteúdo torna-se irrelevante. 


\section{RESULTADOS E ANÁLISE}

A pesquisa de campo foi aplicada em três públicos: professores do curso de administração da FEA-USP e da Universidade Mackenzie, unidades São Paulo e Tamboré, que ministraram aulas para a graduação no ano de 2008 e profissionais de editoras que publicam livros didáticos de administração. O total de professores da USP com essas características é de 71 e do Mackenzie 200. Editoras que publicam livros didáticos de administração são 18, sendo que nesse caso eram aceitos como respondentes mais de um profissional por empresa.

A Tabela 1 resume o número de respondentes:

Tabela 1 - Universo e respondentes

\begin{tabular}{|l|r|r|r|}
\hline & Total & Respondentes & \multicolumn{1}{|c|}{ Percentual } \\
\hline Mackenzie & 200 & 113 & $56,50 \%$ \\
\hline USP & 71 & 32 & $45,07 \%$ \\
\hline Profissionais & 18 & 27 & não se aplica \\
\hline
\end{tabular}

Foram elaboradas 29 frases para as quais cada respondente teve 5 alternativas: Discordo totalmente, discordo, nem concordo nem discordo, concordo e concordo totalmente. Para os professores, as frases eram sobre a adoção de livros didáticos eletrônicos, para os profissionais, eram sobre sua percepção sobre a visão dos professores. Além dessas questões foram aplicadas outras 13 perguntas aos professores e 10 aos profissionais de caráter qualitativo.

\subsection{Apresentação da comparação entre as respostas dos três públicos}

Para identificar as diferenças de percepção sobre a utilização de livros eletrônicos pelos professores e profissionais de editoras, foram apresentadas para cada um dos respondentes 29 frases. Para cada uma delas havia 5 respostas possíveis, sendo atribuídos pontos de 1 (discordo totalmente) até 5 (concordo totalmente). As frases na negativa tiveram pontuação invertida. 
Para a análise de dados foi utilizado o software SPSS versão 15 para Windows. Em um primeiro momento, com intuito de recorrer a testes paramétricos, mais precisamente à comparação de médias, foi avaliado se as variáveis independentes possuíam distribuição normal. Todas elas apontaram valores de curtose e assimetria estatisticamente iguais a zero, concluindo-se que as variáveis tinham distribuição normal. Dessa maneira, foi possível lançarse mão da Análise de variância (ANOVA) para comparação simultânea das médias. A estatística dela derivada é a F de Snedecor, que equivale ao quadrado da estatística t de student - utilizada somente para a comparação de duas médias.

Como requerido para a utilização da ANOVA, a variância de cada uma das 29 variáveis não ultrapassou em 3 vezes a das outras. Ou seja, as médias testadas provem de populações de igual variância e consequentemente a comparação das médias é um recurso legítimo.

Uma vez detectado que as médias dos três grupos não eram todas iguais entre si, ou seja, quando a estatística $\mathrm{F}$ apresentou-se com um nível de significância inferior a 0,05, a análise de contraste de Tukey foi empregada para detectar onde se encontrava a diferença. Sempre adotando um nível de significância de 0,05 , os resultados seguem abaixo.

Como as frases foram formuladas de maneira um pouco diferente para os profissionais das editoras, estão listadas a seguir as duas versões. As médias, os desvios-padrão e os intervalos de confiança de $95 \%$ de cada variável encontram-se no Apêndice 3:

1- Utilizar livros eletrônicos faria com que os alunos tivessem acesso mais rápido à bibliografia do curso.

1- Os professores consideram que utilizar livros eletrônicos faria com que os alunos tivessem acesso mais rápido à bibliografia do curso.

O coeficiente de significância entre os grupos foi de 0,00 .

Após o teste de Tukey os resultados são apresentados na Tabela 2: 
Tabela 2 - Comparação entre os grupos

\begin{tabular}{|l|l|c|c|}
\hline \multicolumn{2}{|l|}{} & Diferença de médias & Significância \\
\hline Profissionais de editoras & Professores USP & $-0,73$ & 0,00 \\
\hline Profissionais de editoras & Professores Mackenzie & $-0,53$ & 0,01 \\
\hline Professores USP & Professores Mackenzie & 0,20 & 0,42 \\
\hline
\end{tabular}

Esse resultado indica que os professores das duas instituições têm a mesma percepção nessa variável. Já os profissionais das editoras apresentam uma média significativamente inferior. Ou seja, apesar de todos concordarem com as afirmações, os profissionais não acreditam, tanto quanto os professores, que livros eletrônicos podem auxiliar na rapidez com que os estudantes acessam sua bibliografia.

2- Indicar livros eletrônicos se encaixaria bem no meu estilo de trabalho.

2- Indicar livros eletrônicos se encaixaria bem no estilo de trabalho dos professores.

O coeficiente de significância entre os grupos foi de 0,00 .

Após o teste de Tukey, os resultados são apresentados na Tabela 3:

Tabela 3 - Comparação entre os grupos

\begin{tabular}{|l|l|c|c|}
\hline \multicolumn{2}{|l|}{} & Diferença de médias & Significância \\
\hline Profissionais de editoras & Professores USP & $-0,79$ & 0,00 \\
\hline Profissionais de editoras & Professores Mackenzie & $-0,83$ & 0,00 \\
\hline Professores USP & Professores Mackenzie & $-0,04$ & 0,97 \\
\hline
\end{tabular}

Os professores da USP e do Mackenzie consideram que a indicação de livros eletrônicos se encaixaria bem no seu estilo de trabalho. Já os profissionais de editoras não acreditam que se encaixaria tão bem.

3- Já tive diversas oportunidades de testar o uso de livros eletrônicos com meus alunos.

3- Os professores têm diversas oportunidades de testar o uso de livros eletrônicos com seus alunos.

O coeficiente de significância entre os grupos foi de 0,00 . 
Após o teste de Tukey, os resultados são apresentados na Tabela 4:

Tabela 4 - Comparação entre os grupos

\begin{tabular}{|l|l|c|c|}
\hline \multicolumn{2}{|l|}{} & Diferença de médias & Significância \\
\hline Profissionais de editoras & Professores USP & 1,07 & 0,00 \\
\hline Profissionais de editoras & Professores Mackenzie & 0,38 & 0,27 \\
\hline Professores USP & Professores Mackenzie & $-0,69$ & 0,01 \\
\hline
\end{tabular}

Todos os grupos tiveram esse fator com média inferior a três, indicando a discordância da afirmação. No entanto, encontrou-se diferença significativa entre os profissionais das editoras e professores da USP e destes com os professores do Mackenzie. Os professores da USP têm média bastante inferior que os do Mackenzie. Uma das possibilidades para essa diferença é que os professores do Mackenzie conhecem bem mais o sistema Pasta do Professor do que os da USP. ${ }^{18}$

4- Acredito que a utilização de livros eletrônicos seria incômoda para meus alunos.

4- Os professores acreditam que seria incômodo para seus alunos o uso de livros eletrônicos.

O coeficiente de significância entre os grupos foi de 0,01 .

Após o teste de Tukey, os resultados são apresentados na Tabela 5:

Tabela 5 - Comparação entre os grupos

\begin{tabular}{|l|l|c|c|}
\hline \multicolumn{2}{|l|}{} & Diferença de médias & Significância \\
\hline Profissionais de editoras & Professores USP & $-0,61$ & 0,03 \\
\hline Profissionais de editoras & Professores Mackenzie & $-0,57$ & 0,01 \\
\hline Professores USP & Professores Mackenzie & 0,04 & 0,98 \\
\hline
\end{tabular}

Os professores tanto da USP quanto os do Mackenzie não acreditam que seria incômodo o uso de livros eletrônicos para seus alunos. Os profissionais das editoras, apesar de concordar com os professores, têm média com diferença significante para os dois grupos de professores (média invertida).

\footnotetext{
${ }^{18}$ Ver Tabela 25.
} 
5- A indicação de livros eletrônicos para meus alunos seria vista com bons olhos pela comunidade acadêmica.

5- Os professores consideram que indicar a utilização de livros eletrônicos seria visto com bons olhos pela comunidade acadêmica.

O coeficiente de significância entre os grupos foi de 0,00 .

Após o teste de Tukey, os resultados são apresentados na Tabela 6:

Tabela 6 - Comparação entre os grupos

\begin{tabular}{|l|l|c|c|}
\hline \multicolumn{2}{|l|}{} & Diferença de médias & Significância \\
\hline Profissionais de editoras & Professores USP & $-0,23$ & 0,60 \\
\hline Profissionais de editoras & Professores Mackenzie & $-0,63$ & 0,01 \\
\hline Professores USP & Professores Mackenzie & $-0,39$ & 0,08 \\
\hline
\end{tabular}

Nessa variável, os profissionais das editoras não têm diferença significante em relação aos professores da USP. Mas ambos diferem dos professores do Mackenzie, que consideram, em maior grau, que a comunidade acadêmica veria com bons olhos a indicação de livros eletrônicos.

6- Tenho visto o trabalho que outros professores desenvolvem com a indicação de livros eletrônicos.

6- Os professores têm como ver que tipo de trabalho seus colegas desenvolvem quando indicam livros eletrônicos.

O coeficiente de significância entre os grupos foi de 0,00 .

Após o teste de Tukey, os resultados são apresentados na Tabela 7:

Tabela 7 - Comparação entre os grupos

\begin{tabular}{|l|l|c|c|}
\hline \multicolumn{2}{|c|}{} & Diferença de médias & Significância \\
\hline Profissionais de editoras & Professores USP & 1,04 & 0,00 \\
\hline Profissionais de editoras & Professores Mackenzie & 0,73 & 0,00 \\
\hline Professores USP & Professores Mackenzie & $-0,31$ & 0,21 \\
\hline
\end{tabular}


Todos os grupos discordam da afirmação. No entanto, os professores dos dois grupos discordam em maior grau e suas médias têm diferença significante em relação à média dos profissionais de editoras.

7- Meus chefes esperam que eu indique livros eletrônicos.

7- Os chefes dos professores esperam que eles indiquem livros eletrônicos.

O coeficiente de significância entre os grupos foi de 0,00 .

Após o teste de Tukey, os resultados são apresentados na Tabela 8:

Tabela 8 - Comparação entre os grupos

\begin{tabular}{|l|l|c|c|}
\hline \multicolumn{2}{|l|}{} & Diferença de médias & Significância \\
\hline Profissionais de editoras & Professores USP & $-0,43$ & 0,20 \\
\hline Profissionais de editoras & Professores Mackenzie & 0,22 & 0,54 \\
\hline Professores USP & Professores Mackenzie & 0,65 & 0,00 \\
\hline
\end{tabular}

Todos os grupos discordam da afirmação. Os profissionais das editoras e professores do Mackenzie não têm diferença significante de percepção nessa variável. Já os professores da USP discordam em maior grau dos outros grupos, chegando a uma diferença significante (média invertida).

8- Eu não teria dificuldade alguma em comunicar a outros os resultados da indicação de livros eletrônicos.

8- Não seria difícil para um professor comunicar os resultados do uso de livros eletrônicos.

O coeficiente de significância entre os grupos foi de 0,00 .

Após o teste de Tukey, os resultados são apresentados na Tabela 9: 
Tabela 9 - Comparação entre os grupos

\begin{tabular}{|l|l|c|c|}
\hline \multicolumn{2}{|l|}{} & Diferença de médias & Significância \\
\hline Profissionais de editoras & Professores USP & $-1,12$ & 0,00 \\
\hline Profissionais de editoras & Professores Mackenzie & $-1,18$ & 0,00 \\
\hline Professores USP & Professores Mackenzie & $-0,06$ & 0,93 \\
\hline
\end{tabular}

Os profissionais das editoras discordam da afirmação. Os professores do Mackenzie e da USP concordam com grau significante de diferença em relação aos primeiros.

9- Eu sei onde posso encontrar livros eletrônicos para testá-los de maneira satisfatória.

9- Os professores sabem onde encontrar livros eletrônicos para poder testá-los de maneira satisfatória.

O coeficiente de significância entre os grupos foi de 0,00 .

Após o teste de Tukey, os resultados são apresentados na Tabela 10:

Tabela 10 - Comparação entre os grupos

\begin{tabular}{|l|l|c|c|}
\hline \multicolumn{2}{|l|}{} & Diferença de médias & Significância \\
\hline Profissionais de editoras & Professores USP & 0,17 & 0,85 \\
\hline Profissionais de editoras & Professores Mackenzie & $-0,86$ & 0,00 \\
\hline Professores USP & Professores Mackenzie & 1,02 & 0,00 \\
\hline
\end{tabular}

Os professores do Mackenzie têm diferença significante para os outros dois grupos, que não tem diferença entre si. A diferença para a USP possivelmente tem ligação com o conhecimento maior dos professores do Mackenzie do sistema Pasta do Professor. ${ }^{19}$

10- A utilização de livros eletrônicos levaria frequentemente a resultados frustrantes.

10- Os professores consideram que o uso de livros eletrônicos levaria, frequentemente, a resultados frustrantes.

O coeficiente de significância entre os grupos foi de 0,00 .

Após o teste de Tukey, os resultados são apresentados na Tabela 11:

\footnotetext{
19 Ver Tabela 25.
} 
Tabela 11 - Comparação entre os grupos

\begin{tabular}{|l|l|c|c|}
\hline \multicolumn{2}{|l|}{} & Diferença de médias & Significância \\
\hline Profissionais de editoras & Professores USP & $-0,35$ & 0,18 \\
\hline Profissionais de editoras & Professores Mackenzie & $-0,54$ & 0,00 \\
\hline Professores USP & Professores Mackenzie & $-0,19$ & 0,42 \\
\hline
\end{tabular}

Não existe diferença significante entre os professores da USP e os outros dois grupos. Existe diferença significante entre os profissionais de editoras e os professores do Mackenzie. Todos os grupos discordam da afirmação (média invertida).

11- Professores que indicassem livros eletrônicos teriam mais prestígio do que aqueles que não indicassem.

11- Professores que indicassem livros eletrônicos teriam mais prestígio do que aqueles que não indicassem.

O coeficiente de significância entre os grupos foi de 0,73 .

Não existe diferença significante entre os três grupos, todos discordando da afirmação.

12- Indicar livros eletrônicos aumentaria a eficiência do meu trabalho.

12- Indicar livros eletrônicos aumentaria a eficiência do trabalho dos professores.

O coeficiente de significância entre os grupos foi de 0,05 .

Não existe diferença significante entre os três grupos.

13- A indicação de livros eletrônicos é voluntária.

13- A indicação de livros eletrônicos é voluntária.

O coeficiente de significância entre os grupos foi de 0,02 .

Após o teste de Tukey, os resultados são apresentados na Tabela 12: 
Tabela 12 - Comparação entre os grupos

\begin{tabular}{|l|l|c|c|}
\hline \multicolumn{2}{|l|}{} & Diferença de médias & Significância \\
\hline Profissionais de editoras & Professores USP & $-0,53$ & 0,03 \\
\hline Profissionais de editoras & Professores Mackenzie & 0,44 & 0,03 \\
\hline Professores USP & Professores Mackenzie & 0,09 & 0,82 \\
\hline
\end{tabular}

Existe diferença significante entre profissionais de editoras e os professores da USP e do Mackenzie. Os professores dos dois grupos têm médias altas, concordando com a voluntariedade da decisão sobre adotar ou não livros eletrônicos.

14- Acredito que poderia comunicar a outros as consequências da indicação de livros eletrônicos.

14- Os professores poderiam comunicar as consequências da indicação de livros eletrônicos.

O coeficiente de significância entre os grupos foi de 0,00 .

Após o teste de Tukey, os resultados são apresentados na Tabela 13:

Tabela 13 - Comparação entre os grupos

\begin{tabular}{|l|l|c|c|}
\hline \multicolumn{2}{|l|}{} & Diferença de médias & Significância \\
\hline Profissionais de editoras & Professores USP & $-0,52$ & 0,04 \\
\hline Profissionais de editoras & Professores Mackenzie & $-0,63$ & 0,00 \\
\hline Professores USP & Professores Mackenzie & $-0,12$ & 0,74 \\
\hline
\end{tabular}

Existe diferença significante entre profissionais de editoras e os professores da USP e do Mackenzie. Os professores dos dois grupos têm médias mais altas de concordância.

15- Se eu indicasse livros eletrônicos teria maior controle sobre o meu trabalho.

15- Indicar livros eletrônicos daria maior controle aos professores sobre o seu trabalho.

O coeficiente de significância entre os grupos foi de 0,28 .

Não existe diferença significante entre os três grupos, todos, em média, discordando da afirmação. 
16- Livros eletrônicos estão disponíveis para que eu possa testá-los adequadamente.

16- Os professores têm à disposição livros eletrônicos para poder testá-los adequadamente.

O coeficiente de significância entre os grupos foi de 0,02 .

Após o teste de Tukey, os resultados são apresentados na Tabela 14:

Tabela 14 - Comparação entre os grupos

\begin{tabular}{|l|l|c|c|}
\hline \multicolumn{2}{|l|}{} & Diferença de médias & Significância \\
\hline Profissionais de editoras & Professores USP & $-0,05$ & 0,84 \\
\hline Profissionais de editoras & Professores Mackenzie & $-0,46$ & 0,03 \\
\hline Professores USP & Professores Mackenzie & $-0,41$ & 0,04 \\
\hline
\end{tabular}

Não existe diferença significante entre profissionais de editoras e professores da USP. Entretanto, existe diferença entre esses dois grupos e professores do Mackenzie. Todos os grupos discordam da afirmação.

17- Aprender a utilizar livros eletrônicos seria fácil para meus alunos.

17- Os professores acreditam que seria fácil para seus alunos aprender a utilizar livros eletrônicos.

O coeficiente de significância entre os grupos foi de 0,13 .

Não houve diferença significante entre os três grupos, todos concordando com a afirmação.

18- Na faculdade onde leciono, diversos professores indicam livros eletrônicos.

18- Diversos professores indicam livros eletrônicos.

O coeficiente de significância entre os grupos foi de 0,00 .

Após o teste de Tukey, os resultados são apresentados na Tabela 15: 
Tabela 15 - Comparação entre os grupos

\begin{tabular}{|l|l|c|c|}
\hline \multicolumn{2}{|l|}{} & Diferença de médias & Significância \\
\hline Profissionais de editoras & Professores USP & 0,41 & 0,08 \\
\hline Profissionais de editoras & Professores Mackenzie & $-0,28$ & 0,17 \\
\hline Professores USP & Professores Mackenzie & $-0,69$ & 0,00 \\
\hline
\end{tabular}

Entre profissionais de editoras e professores da USP não houve diferença significante. Os dois grupos tiveram diferença significante em relação aos professores do Mackenzie. Estes apresentaram grau de discordância menor.

19- Indicar livros eletrônicos aumentaria minha produtividade.

19- Indicar livros eletrônicos aumentaria a produtividade dos professores.

O coeficiente de significância entre os grupos foi de 0,97 .

Não houve diferença significante entre os grupos, todos, em média, discordando da afirmação.

20- É fácil observar outros utilizando livros eletrônicos na faculdade.

20- É fácil para professores observar outros utilizando livros eletrônicos nas faculdades.

O coeficiente de significância entre os grupos foi de 0,02 .

Após o teste de Tukey os resultados são apresentados na Tabela 16:

Tabela 16: Comparação entre os grupos

\begin{tabular}{|l|l|c|c|}
\hline & & Diferença de médias & Significância \\
\hline Profissionais de editoras & Professores USP & 0,63 & 0,02 \\
\hline Profissionais de editoras & Professores Mackenzie & 0,28 & 0,28 \\
\hline Professores USP & Professores Mackenzie & $-0,35$ & 0,10 \\
\hline
\end{tabular}

Existe diferença de significância entre os profissionais de editoras e professores da USP, tendo esses últimos menor média. Não houve diferença significante entre os professores do Mackenzie e os outros dois grupos. Todos discordaram da afirmação. 
21- Apesar de ser possivelmente positivo, indicar livros eletrônicos não é obrigatório em meu trabalho.

21- Apesar de ser possivelmente positivo, indicar livros eletrônicos não é obrigatório para os professores.

O coeficiente de significância entre os grupos foi de 0,06 .

Não houve diferença significante entre os grupos, todos, em média, concordando com a afirmação.

22- Os resultados da utilização do livro eletrônico seriam claros para mim.

22- Os resultados da utilização de livros eletrônicos seriam claros para o professor.

O coeficiente de significância entre os grupos foi de 0,19 .

Não houve diferença significante entre os grupos.

23- Eu indicaria livros eletrônicos caso fossem mais baratos que os impressos.

23- Os professores indicariam livros eletrônicos caso fossem mais baratos do que os impressos.

O coeficiente de significância entre os grupos foi de 0,46 .

Os três grupos não apresentaram diferença significante, todos concordando com a afirmação.

24- Eu não tenho oportunidades adequadas para testar os diferentes usos de um livro eletrônico.

24- Os professores não têm oportunidades adequadas para testar os diferentes usos de um livro eletrônico.

O coeficiente de significância entre os grupos foi de 0,32 .

Não há diferença significante na resposta dos três grupos, todos concordando com a negativa (médias invertidas). 
25- Meus alunos teriam facilidade em utilizar livros eletrônicos por estarem acostumados com o formato digital.

25- Os professores acreditam que seus alunos teriam facilidade de utilizar livros eletrônicos por estarem acostumados com o formato digital.

O coeficiente de significância entre os grupos foi de 0,67.

Não existe diferença significante entre os grupos, todos concordando com a afirmação.

26- Existem poucos títulos de livros eletrônicos disponíveis, o que dificulta a sua indicação. 26- Por existirem poucos títulos de livros eletrônicos disponíveis, os professores têm dificuldade em indicá-los.

O coeficiente de significância entre os grupos foi de 0,68.

Não existe diferença significante entre os grupos, todos concordando com a afirmação (médias invertidas).

27- Eu indicaria livros eletrônicos caso fossem vendidos em partes.

27- Os professores indicariam livros eletrônicos caso fossem vendidos em partes.

O coeficiente de significância entre os grupos foi de 0,92 .

Não existe diferença significante entre os grupos, todos concordando com a afirmação.

28- O surgimento de dispositivos de leitura de livros eletrônicos, que fazem a experiência de leitura em tela mais agradável, faria com que eu indicasse, com mais frequência, livros eletrônicos.

28- O surgimento de dispositivos de leitura de livros eletrônicos, que fazem a experiência de leitura em tela mais agradável, fará com que os professores indiquem, com mais frequência, livros eletrônicos.

O coeficiente de significância entre os grupos foi de 0,61 . 
Não existe diferença significante entre os grupos, todos concordando com a afirmação.

29- Uma tentativa real de testar os vários usos do livro eletrônico no dia a dia não é possível. 29- Para os professores não é possível testar os vários usos do livro eletrônico de maneira real no seu dia a dia.

O coeficiente de significância entre os grupos foi de 0,00 .

Após o teste de Tukey, os resultados são apresentados na Tabela 17:

Tabela 17 - Comparação entre os grupos

\begin{tabular}{|l|l|c|c|}
\hline \multicolumn{2}{|c|}{} & Diferença de médias & Significância \\
\hline Profissionais de editoras & Professores USP & $-0,70$ & 0,01 \\
\hline Profissionais de editoras & Professores Mackenzie & $-0,95$ & 0,00 \\
\hline Professores USP & Professores Mackenzie & $-0,26$ & 0,34 \\
\hline
\end{tabular}

Houve diferença significante entre profissionais de editoras e professores das duas instituições. Não houve diferença entre os professores. Os professores têm grau de discordância maior da afirmação (média invertida).

O Quadro 2 apresenta as frases com as diferenças significantes entre os três públicos de maneira consolidada 
Quadro 2 - Diferenças significantes consolidadas

\begin{tabular}{|c|c|c|c|}
\hline & Editoras & USP & Mackenzie \\
\hline $\begin{array}{l}\text { Utilizar livros eletrônicos faria com que os alunos tivessem acesso mais rápido } \\
\text { à bibliografia do curso }\end{array}$ & $\mathrm{U} / \mathrm{M}$ & E & $\mathrm{E}$ \\
\hline Indicar livros eletrônicos aumentaria a eficiência do meu trabalho & - & - & - \\
\hline Se eu indicasse livros eletrônicos teria maior controle sobre o meu trabalho & - & - & - \\
\hline Indicar livros eletrônicos aumentaria minha produtividade & - & - & - \\
\hline Eu indicaria livros eletrônicos caso fossem mais baratos que os impressos & - & - & - \\
\hline Eu indicaria livros eletrônicos caso fossem vendidos em partes & - & - & - \\
\hline Indicar livros eletrônicos se encaixaria bem no meu estilo de trabalho & $\mathrm{U} / \mathrm{M}$ & $\mathrm{E}$ & $\mathrm{E}$ \\
\hline $\begin{array}{l}\text { Já tive diversas oportunidades de testar o uso de livros eletrônicos com meus } \\
\text { alunos }\end{array}$ & $\mathrm{U}$ & $\mathrm{E} / \mathrm{M}$ & $\mathrm{U}$ \\
\hline $\begin{array}{l}\text { Eu sei onde posso encontrar livros eletrônicos para testá-los de maneira } \\
\text { satisfatória }\end{array}$ & $\mathrm{M}$ & $\mathrm{M}$ & $\mathrm{E} / \mathrm{U}$ \\
\hline Livros eletrônicos estão disponíveis para que eu possa testá-los adequadamente & M & M & $\mathrm{E} / \mathrm{U}$ \\
\hline $\begin{array}{l}\text { Eu não tenho oportunidades adequadas para testar os diferentes usos de um } \\
\text { livro eletrônico }\end{array}$ & - & - & - \\
\hline $\begin{array}{l}\text { Existem poucos títulos de livros eletrônicos disponíveis, o que dificulta a sua } \\
\text { indicação. }\end{array}$ & - & - & - \\
\hline $\begin{array}{l}\text { Uma tentativa real de testar os vários usos do livro eletrônico no dia a dia não é } \\
\text { possível }\end{array}$ & $\mathrm{U} / \mathrm{M}$ & $\mathrm{E}$ & $\mathrm{E}$ \\
\hline Acredito que a utilização de livros eletrônicos seria incômoda para meus alunos & $\mathrm{U} / \mathrm{M}$ & $\mathrm{E}$ & $\mathrm{E}$ \\
\hline $\begin{array}{l}\text { A utilização de livros eletrônicos levaria frequentemente a resultados } \\
\text { frustrantes }\end{array}$ & $\mathrm{M}$ & - & $\mathrm{E}$ \\
\hline Aprender a utilizar livros eletrônicos seria fácil para meus alunos & - & - & - \\
\hline $\begin{array}{l}\text { Meus alunos teriam facilidade em utilizar livros eletrônicos por estarem } \\
\text { acostumados com o formato digital }\end{array}$ & - & - & - \\
\hline $\begin{array}{l}\text { O surgimento de dispositivos de leitura de livros eletrônicos que fazem a } \\
\text { experiência de leitura em tela mais agradável faria com que eu indicasse, com } \\
\text { mais frequência, livros eletrônicos. }\end{array}$ & - & - & - \\
\hline $\begin{array}{l}\text { A indicação de livros eletrônicos para meus alunos seria vista com bons olhos } \\
\text { pela comunidade acadêmica }\end{array}$ & M & - & $\mathrm{E}$ \\
\hline $\begin{array}{l}\text { Professores que indicassem livros eletrônicos teriam mais prestígio do que } \\
\text { aqueles que não indicassem }\end{array}$ & - & - & - \\
\hline $\begin{array}{l}\text { Tenho visto o trabalho que outros professores desenvolvem com a indicação de } \\
\text { livros eletrônicos }\end{array}$ & $\mathrm{U} / \mathrm{M}$ & $\mathrm{E}$ & $\mathrm{E}$ \\
\hline $\mathrm{Na}$ faculdade onde leciono diversos professores indicam livros eletrônicos. & - & M & $\mathrm{U}$ \\
\hline É fácil observar outros utilizando livros eletrônicos na faculdade & $\mathrm{U}$ & $\mathrm{E}$ & - \\
\hline Meus chefes esperam que eu indique livros eletrônicos & - & M & $\mathrm{U}$ \\
\hline A indicação de livros eletrônicos é voluntária & $\mathrm{U} / \mathrm{M}$ & $\mathrm{E}$ & $\mathrm{E}$ \\
\hline $\begin{array}{l}\text { Apesar de ser possivelmente positivo, indicar livros eletrônicos não é } \\
\text { obrigatório em meu trabalho. }\end{array}$ & - & - & - \\
\hline $\begin{array}{l}\text { Eu não teria dificuldade alguma em comunicar a outros os resultados da } \\
\text { indicação de livros eletrônicos }\end{array}$ & $\mathrm{U} / \mathrm{M}$ & E & $\mathrm{E}$ \\
\hline $\begin{array}{l}\text { Acredito que poderia comunicar a outros as consequências da indicação de } \\
\text { livros eletrônicos }\end{array}$ & $\mathrm{U} / \mathrm{M}$ & E & $\mathrm{E}$ \\
\hline Os resultados da utilização do livro eletrônico seriam claros para $\mathrm{n}$ & - & - & - \\
\hline
\end{tabular}

No quadro, a letra E representa os profissionais de editoras, a letra U os professores da USP e a letra M os professores do Mackenzie. Em cada coluna onde se encontra uma dessas letras é 
porque houve diferença significante entre o público da coluna e o público representado pela letra para cada linha (variável).

Das 29 variáveis, 13 não tiveram diferença significante entre os 3 públicos. Das 16 em que isso ocorreu, em 8 houve diferença entre as respostas dos profissionais de editoras e dos professores de Mackenzie e USP; 1 entre os professores da USP e os profissionais de editoras e professores do Mackenzie; 2 entre os professores do Mackenzie e os profissionais de editoras e professores da USP; 2 entre os profissionais de editoras e os professores do Mackenzie; 2 entre os professores do Mackenzie e da USP e uma entre os profissionais de editoras e os professores da USP.

Apesar de diversas diferenças entre o perfil de professores do Mackenzie e da USP, apenas cinco frases apresentaram médias com diferença significante entre os grupos. Existem, portanto, poucas diferenças de percepção sobre o possível uso de livros eletrônicos entre os dois grupos.

Já os profissionais de editoras apresentaram 14 médias com diferença significante em relação aos grupos de professores. Essa percepção pode estar ligada às respostas da pergunta 9 referente às qualitativas para profissionais de editoras, onde a maior parte deles respondeu que acredita ser improvável que livros eletrônicos venham a ser o principal produto da indústria editorial até 2015 .

\subsection{Apresentação da comparação entre os fatores}

As variáveis analisadas no item 4.1 pertencem a oito fatores descritos no item 2.5 desta pesquisa, adoção de inovação. As variáveis agrupadas em seus fatores e respectivas médias são apresentadas na Tabela 18, a seguir. 
Tabela 18 - Média das variáveis e fatores

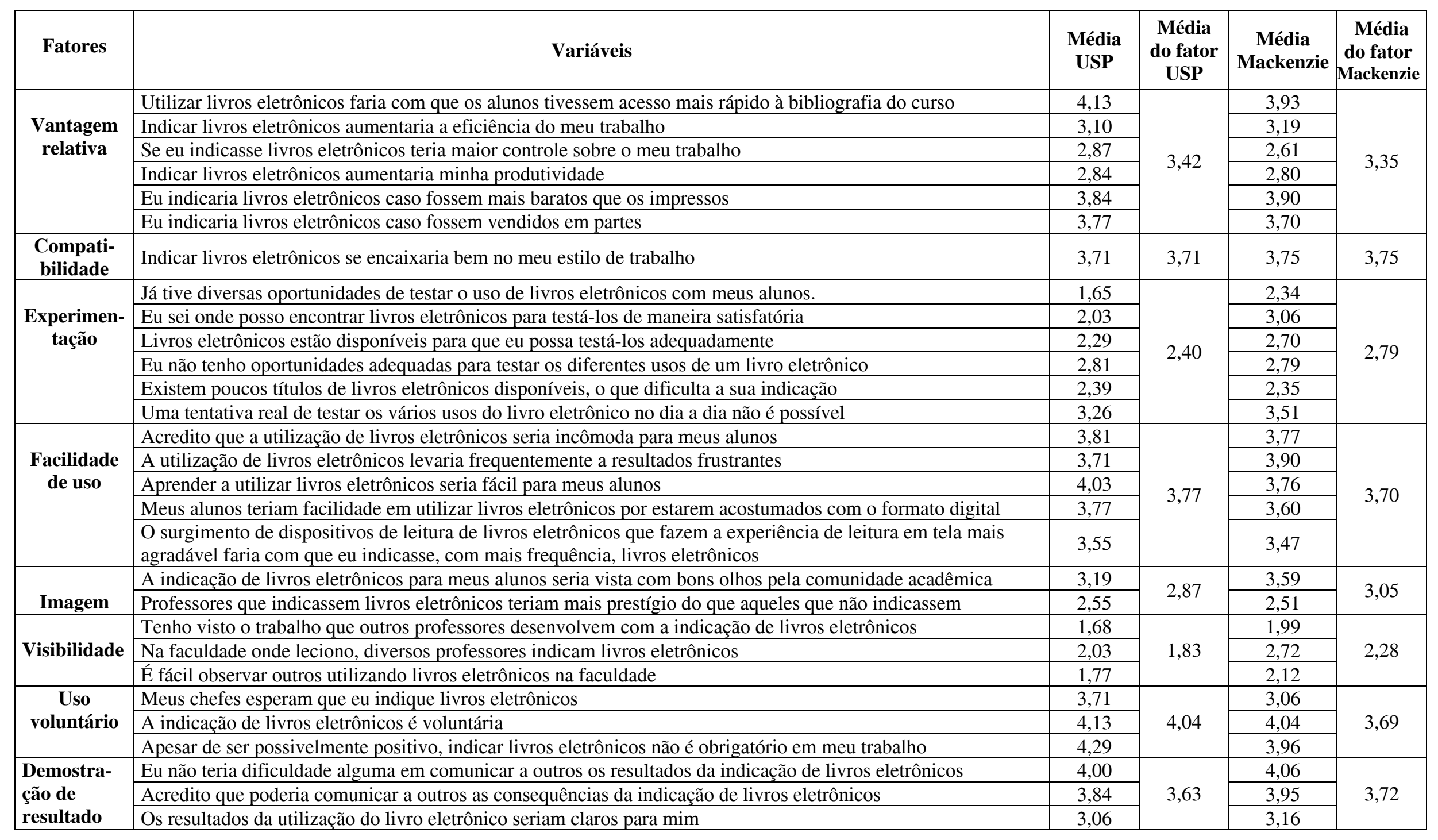


Para se comparar os resultados dos fatores das amostras de professores, foi utilizado o software SPSS versão 15 para Windows. Verificou-se que as médias dos todos os fatores tinham distribuição normal, uma vez que curtose e assimetria revelaram-se estatisticamente iguais a zero. Todas as variâncias dessas médias superavam em mais de três vezes a das outras ao se passar de um fator a outro. Portanto, como as variáveis eram independentes, revelou-se legítimo o uso da Analise de Variância - ANOVA.

Uma vez detectado que as médias dos dois grupos não eram todas iguais entre si, ou seja, quando a estatística $\mathrm{F}$ apresentou-se com um nível de significância inferior a 0,05, a análise de contraste de Tukey foi empregada para detectar onde se encontrava a diferença. As tabelas com os detalhes deste resultado encontram-se no Apêndice 7.

Nas Ilustrações 3 e 4, apresentam-se as distribuições dos fatores segundo seu grau de motivação para os professores da USP e do Mackenzie.

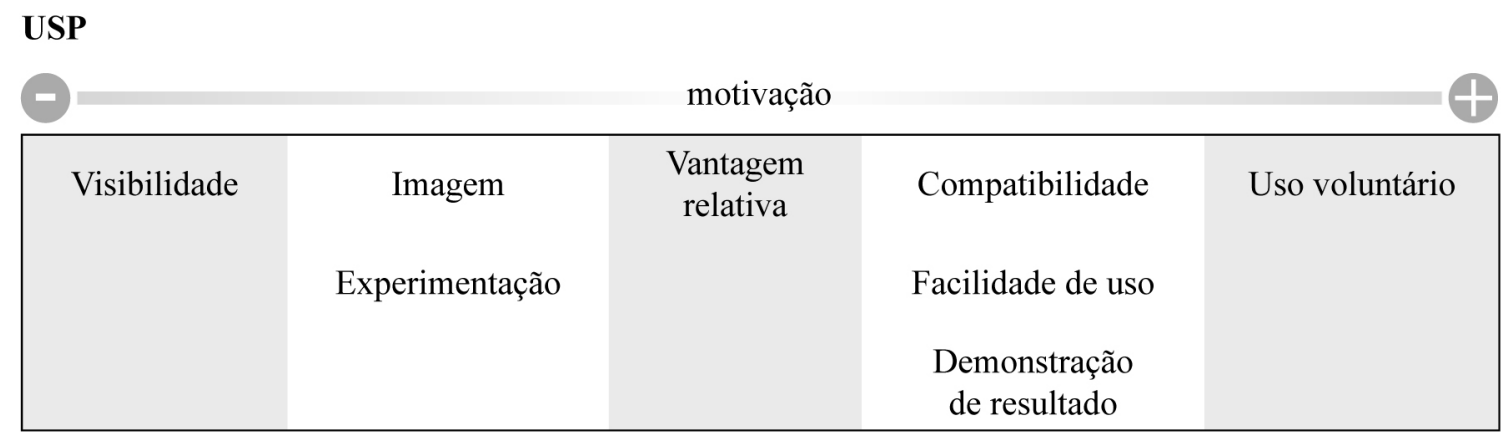

Ilustração 3 - Fatores ordenados por motivação - professores da USP

\section{Mackenzie}

\begin{tabular}{|c|c|c|c|}
\hline \multirow[t]{4}{*}{ Visibilidade } & Imagem & Vantagem relativa & Compatibilidade \\
\hline & Experimentação & & Facilidade de uso \\
\hline & & & $\begin{array}{c}\text { Demonstração } \\
\text { de resultado }\end{array}$ \\
\hline & & & Uso voluntário \\
\hline
\end{tabular}

Ilustração 4 - Fatores ordenados por motivação - professores do Mackenzie 
Os gráficos mostram que, apesar de médias bastante diferentes em alguns fatores, o agrupamento em relação à motivação é muito próximo. Apenas uso voluntário é o maior fator de motivação para os professores da USP solitariamente, ao passo que no caso dos professores do Mackenzie divide esse posto com outros três fatores. Todos os outros sete fatores obedecem a mesma ordem de importância no caso dos dois grupos.

\subsection{Apresentação das respostas qualitativas: Professores}

Foram aplicadas 13 perguntas qualitativas para os professores a fim de qualificá-los e saber sua opinião sobre assuntos específicos. Desse total, cinco tiveram resultados pouco conclusivos ou pouco importantes fazendo com que a apresentação de seus resultados não fosse relevante. As outras 8 perguntas seguem abaixo com as respectivas respostas e breve análise.

Na Tabela 19, nota-se uma diferença grande na média de idade entre os professores da USP e os do Mackenzie.

Tabela 19 - Média de idade

\begin{tabular}{|c|c|}
\hline \multicolumn{2}{|c|}{ Média de idade - Anos } \\
\hline USP & Mackenzie \\
\hline 54,6 & 44,3 \\
\hline
\end{tabular}

A Tabela 20 apresenta há quanto tempo cada grupo leciona. 
Tabela 20 - Tempo como docente

\begin{tabular}{|c|c|c|c|c|c|}
\hline \multicolumn{6}{|c|}{ Há quanto tempo leciona no ensino superior? } \\
\hline & & \multicolumn{2}{|c|}{ Frequência } & \multicolumn{2}{|c|}{ Percentual } \\
\hline & & USP & Mackenzie & USP & Mackenzie \\
\hline \multirow{4}{*}{$\begin{array}{l}\text { Respostas } \\
\text { válidas }\end{array}$} & Até 10 anos & 1 & 76 & 3,1 & 67,3 \\
\hline & $\begin{array}{l}\text { Entre } 11 \text { e } 25 \\
\text { anos }\end{array}$ & 12 & 31 & 37,5 & 27,4 \\
\hline & $\begin{array}{l}\text { Mais de } 25 \\
\text { anos }\end{array}$ & 18 & 4 & 56,3 & 3,5 \\
\hline & Total & 31 & 111 & 96,9 & 98,2 \\
\hline Não respondido & & 1 & 2 & 3,1 & 1,8 \\
\hline Total & & 32 & 113 & 100,0 & 100,0 \\
\hline
\end{tabular}

A diferença de idade média reflete na grande diferença em termos de experiência em sala de aula. A maior parte dos professores do Mackenzie atua há menos de 10 anos. No caso de professores da USP, a maior parte atua há mais de 25 anos.

A Tabela 21 apresenta o número de professores de cada grupo que são autores de livros.

Tabela 21 - Professores que são autores

\begin{tabular}{|l|l|r|r|r|r|}
\hline \multicolumn{2}{|c|}{ O (a) senhor (a) tem livros publicados (como autor (a), organizador (a) ou } \\
coautor (a))?
\end{tabular}

Por essa tabela também se pode notar a diferença na experiência em publicação de livros entre os grupos de professores. Enquanto quase $90 \%$ dos professores da USP têm livros publicados, apenas 32\% dos professores do Mackenzie publicaram algum.

A Tabela 22 informa quantos professores de cada grupo indicam livros como leitura obrigatória nas matérias que leciona 
Tabela 22: Professores que indicam livros

\begin{tabular}{|c|c|c|c|c|c|}
\hline \multicolumn{6}{|c|}{ O(a) senhor(a) indica livros para leitura obrigatória nas matérias que leciona? } \\
\hline & & \multicolumn{2}{|c|}{ Frequência } & \multicolumn{2}{|c|}{ Percentual } \\
\hline & & USP & Mackenzie & USP & Mackenzie \\
\hline \multirow[t]{4}{*}{ Respostas válidas } & Sim & 23 & 94 & 71,9 & 83,2 \\
\hline & Não & 3 & 1 & 9,4 & 0,9 \\
\hline & Eventualmente & 5 & 16 & 15,6 & 14,2 \\
\hline & Total & 31 & 111 & 96,9 & 98,2 \\
\hline Não respondido & & 1 & 2 & 3,1 & 1,8 \\
\hline \multicolumn{2}{|l|}{ Total } & 32 & 113 & 100,0 & 100,0 \\
\hline
\end{tabular}

Nota-se nessa tabela um alto índice de indicação de livros para leitura obrigatória nas duas faculdades.

Na Tabela 23, informa-se quantos professores já utilizaram livros eletrônicos.

Tabela 23 - Utilização de livros eletrônicos

\begin{tabular}{|l|l|r|r|r|r|}
\hline \multicolumn{2}{|c|}{ O (a) senhor(a) já utilizou livros eletrônicos para fins de trabalho ou lazer? } \\
\hline \multicolumn{2}{|c|}{} & \multicolumn{2}{|c|}{ Frequência } & \multicolumn{2}{c|}{ Percentual } \\
\cline { 2 - 6 } & USP & Mackenzie & USP & Mackenzie \\
\hline $\begin{array}{l}\text { Respostas } \\
\text { válidas }\end{array}$ & Sim & 8 & 48 & 25,0 & 42,5 \\
\cline { 2 - 6 } & Não & 23 & 61 & 71,9 & 54,0 \\
\cline { 2 - 7 } & Total & 31 & 109 & 96,9 & 96,5 \\
\hline \multirow{2}{*}{ Não respondido } & & 1 & 4 & 3,1 & 3,5 \\
\hline Total & & 32 & 113 & 100,0 & 100,0 \\
\hline
\end{tabular}

Essa tabela dá indícios de que os professores do Mackenzie são mais habituados com livros eletrônicos do que os professores da USP.

Na Tabela 24, apresenta-se o número de professores que indica ou já indicou livros eletrônicos a seus alunos. 
Tabela 24 - Indicação de livros eletrônicos para alunos

\begin{tabular}{|l|l|r|r|r|r|}
\hline \multirow{2}{*}{ O(a) senhora(a) indica ou já indicou livros eletrônicos para seus alunos de graduação? } \\
\hline \multicolumn{2}{|c|}{} & \multicolumn{2}{c|}{ Frequência } & \multicolumn{2}{c|}{ Percentual } \\
\cline { 2 - 6 } & USP & Mackenzie & USP & Mackenzie \\
\hline \multirow{3}{*}{ Respostas válidas } & Sim & 2 & 30 & 6,3 & 26,5 \\
\cline { 2 - 6 } & Não & 29 & 79 & 90,6 & 69,9 \\
\cline { 2 - 6 } & Total & 31 & 109 & 96,9 & 96,5 \\
\hline Não respondido & & 1 & 4 & 3,1 & 3,5 \\
\hline Total & 32 & 113 & 100,0 & 100,0 \\
\hline
\end{tabular}

Por essa tabela, os indícios de que os professores do Mackenzie são mais habituados com livros eletrônicos do que os da USP ficam mais fortes, por conta de uma diferença considerável no percentual de professores que os indicam a seus alunos.

A Tabela 25 apresenta o número de professores que conhece o modelo de negócio "Pasta do Professor".

Tabela 25 - Modelo de negócio "Pasta do Professor"

\begin{tabular}{|l|l|r|r|r|r|}
\hline \multicolumn{2}{|c|}{$\begin{array}{c}\text { O(a) senhora(a) conhece o modelo de negócio para venda de livros por capítulos } \\
\text { impressos chamado Pasta do Professor? }\end{array}$} \\
\hline \multirow{2}{*}{} & \multicolumn{2}{c|}{ Frequência } & \multicolumn{2}{c|}{ Percentual } \\
\cline { 3 - 7 } & \multicolumn{2}{|c|}{ USP } & Mackenzie & USP & Mackenzie \\
\hline \multirow{2}{*}{ Respostas válidas } & Sim & 18 & 91 & 56,3 & 80,5 \\
\cline { 2 - 7 } & Não & 13 & 18 & 40,6 & 15,9 \\
\cline { 2 - 7 } & Total & 31 & 109 & 96,9 & 96,5 \\
\hline Não respondido & & 1 & 4 & 3,1 & 3,5 \\
\hline Total & & 32 & 113 & 100,0 & 100,0 \\
\hline
\end{tabular}

Mais um indício de que os professores do Mackenzie são mais habituados com o livro digital do que os da USP aparece na diferença entre os percentuais dos professores que conhecem o modelo Pasta do Professor. As duas faculdades disponibilizam esse produto em suas dependências.

A Tabela 26 apresenta quais as características mais relevantes de livros didáticos eletrônicos. 
Tabela 26 - Características mais relevantes de livros eletrônicos

Qual(is) característica(as) de livros eletrônicos listada(as) abaixo o(a) senhor(a) considera relevante(es) para uma eventual utilização em sala de aula como material pedagógico?

\begin{tabular}{|c|c|c|c|c|c|}
\hline \multirow{2}{*}{$\begin{array}{l}\text { Motivos para utilizar/indicar } \\
\text { o livro eletrônico }\end{array}$} & \multicolumn{2}{|c|}{ Frequência } & \multicolumn{2}{|c|}{ Percentual } & \multirow{2}{*}{$\begin{array}{c}\text { Média } \\
\text { Percentual }\end{array}$} \\
\hline & USP & Mackenzie & USP & Mackenzie & \\
\hline $\begin{array}{l}\text { Acesso conveniente pela internet } 24 \text { horas } \\
\text { por dia }\end{array}$ & 26 & 99 & 81,3 & 91,0 & 86,2 \\
\hline Podem ser vendidos em partes & 25 & 97 & 78,1 & 89,0 & 83,6 \\
\hline Facilidade de busca & 23 & 80 & 71,9 & 73,0 & 72,5 \\
\hline $\begin{array}{l}\text { Podem ser carregados em pequenos } \\
\text { dispositivos }\end{array}$ & 18 & 70 & 56,3 & 64,0 & 60,2 \\
\hline Podem ser atualizados a qualquer momento & 17 & 67 & 53,1 & 61,0 & 57,1 \\
\hline $\begin{array}{l}\text { Podem ser conectados por meio de } \\
\text { hipertexto (links) }\end{array}$ & 20 & 52 & 62,5 & 48,0 & 55,3 \\
\hline Podem oferecer informações multimídia & 16 & 59 & 50,0 & 54,0 & 52,0 \\
\hline Podem oferecer arquivos sonoros & 14 & 35 & 43,8 & 32,0 & 37,9 \\
\hline As cópias são perfeitas & 8 & 38 & 25,0 & 35,0 & 30,0 \\
\hline $\begin{array}{l}\text { Possibilidade de alterar o tamanho e o tipo } \\
\text { das fontes }\end{array}$ & 10 & 28 & 31,3 & 26,0 & 28,7 \\
\hline Nenhuma & 2 & 0 & 6,3 & 0,0 & 3,2 \\
\hline Outras & 0 & 10 & 0,0 & 9,0 & 4,5 \\
\hline
\end{tabular}

A principal vantagem que os livros eletrônicos têm sobre o impresso para os professores pesquisados é o acesso conveniente. Outras características tidas como vantagens relevantes são o fato de poderem ser vendidos em partes, a facilidade de busca, poderem ser carregados em pequenos dispositivos, capacidade de serem atualizados a qualquer momento, poderem ser conectados por meio de hipertexto e oferecer informações multimídia. O fato de o livro eletrônico poder ser apresentado como arquivo sonoro, poder gerar cópias perfeitas e ser possível alterar o tamanho e o tipo das fontes não foram consideradas características importantes.

Foram citados também os benefícios ao meio ambiente por conta da não utilização de papel e a possibilidade de serem indicados em sistemas de ensino à distância.

\subsection{Apresentação das respostas qualitativas: Profissionais de editoras}

Foram aplicadas dez perguntas qualitativas para os profissionais de editoras, a fim de qualificá-los e saber sua opinião sobre assuntos específicos. Desse total, quatro tiveram 
resultados pouco conclusivos ou pouco importantes fazendo com que a apresentação de seus resultados não fosse relevante. As outras seis perguntas seguem abaixo com as respectivas respostas e breve análise.

A Tabela 27 apresenta a idade média dos profissionais de editoras

Tabela 27 - Idade

Média de idade - Anos

40,4

A média de idade dos profissionais é relativamente baixa quando comparada com a dos professores, principalmente da USP.

A Tabela 28 apresenta o tempo de cada profissional em editoras de livros didáticos de ensino superior.

Tabela 28 - Tempo como profissional

\begin{tabular}{|c|c|c|c|}
\hline \multicolumn{4}{|c|}{$\begin{array}{l}\text { Tempo como profissional do setor editorial de livros } \\
\text { didáticos de ensino superior }\end{array}$} \\
\hline & & Frequência & Percentual \\
\hline \multirow{4}{*}{$\begin{array}{l}\text { Respostas } \\
\text { válidas }\end{array}$} & Até 10 anos & 12 & 44,4 \\
\hline & $\begin{array}{l}\text { Entre } 11 \mathrm{e} \\
25 \text { anos }\end{array}$ & 9 & 33,3 \\
\hline & $\begin{array}{l}\text { Mais de } 25 \\
\text { anos }\end{array}$ & 6 & 22,2 \\
\hline & Total & 27 & 100,0 \\
\hline
\end{tabular}

Apesar de a pesquisa ter atingido donos e profissionais graduados das empresas, nota-se que boa parte dos respondentes tem relativamente pouca experiência no mercado editorial, pelo menos de livros didáticos de ensino superior.

A tabela 29 apresenta o número de empresas que trabalham com a comercialização de livros eletrônicos. 
Tabela 29 - Comercialização de livros eletrônicos

\begin{tabular}{|l|l|r|r|}
\hline \multicolumn{4}{|c|}{$\begin{array}{c}\text { A empresa na qual trabalha comercializa livros } \\
\text { eletrônicos? }\end{array}$} \\
\hline \multicolumn{2}{|c|}{} & Frequência & Percentual \\
\hline \multirow{2}{*}{$\begin{array}{l}\text { Respostas } \\
\text { válidas }\end{array}$} & Sim & 16 & 59,3 \\
\cline { 2 - 4 } & Não & 9 & 33,3 \\
\cline { 2 - 4 } & Total & 25 & 92,6 \\
\hline Não respondido & & 2 & 7,4 \\
\hline Total & & 27 & 100,0 \\
\hline
\end{tabular}

Nessa pergunta, alguns respondentes se confundiram e não responderam positivamente, apesar de o pesquisador ter conhecimento de que as empresas nas quais trabalham comercializam livros eletrônicos. Após executar novamente a pesquisa, chega-se a 19 respondentes, que representam $12(70 \%)$ das editoras pesquisadas.

A Tabela 30 apresenta o tipo de modelo utilizado.

Tabela 30 - Modelo de comercialização de livros eletrônicos.

\begin{tabular}{|l|l|c|c|}
\hline \multicolumn{4}{|c|}{ Em caso positivo, que modelo de comercialização } \\
utiliza?
\end{tabular}

O mesmo caso da pergunta anterior. Após executar novamente a pesquisa, chega-se a 19 profissionais de 12 editoras que trabalham com modelos de comercialização de livros eletrônicos, aumentando para 8 o número de repostas do item "Pasta do Professor".

A Tabela 31 apresenta os motivos para não existir oferta variada de títulos de livros eletrônicos. 
Tabela 31 - Motivos para pouca oferta de títulos de livros eletrônicos.

\begin{tabular}{|c|c|c|}
\hline \multicolumn{3}{|c|}{$\begin{array}{c}\text { Quais são os principais motivos para não existir oferta variada de títulos em modelos de negócio de } \\
\text { livros eletrônicos? }\end{array}$} \\
\hline & Marcaram & Percentual \\
\hline Temor das editoras de que haja aumento de reproduções não autorizadas & 17 & 63,0 \\
\hline Indefinição quanto ao formato em que deve ser oferecido & 11 & 40,7 \\
\hline Problemas das editoras com a liberação de direitos autorais & 10 & 37,0 \\
\hline Falta de interesse do consumidor & 6 & 22,2 \\
\hline Falta de interesse das editoras, não sei o motivo. & 5 & 18,5 \\
\hline Outro(s) motivo(s) & 5 & 18,5 \\
\hline
\end{tabular}

O temor do aumento de reproduções não autorizadas é o maior impeditivo para que as editoras ofereçam uma maior quantidade de títulos de livros eletrônicos. O segundo item mais importante é o fato de não existir um formato padrão a ser oferecido. Existem diversos modelos de negócio, mas nenhum predominante. O terceiro ponto também citado com relevância trata-se de problemas com a liberação de direitos autorais. Os outros motivos citados estão de alguma maneira ligados aos apresentados no quadro.

A Tabela 32 apresenta a opinião dos profissionais sobre a possibilidade de livros impressos deixarem de ser o principal produtos para as editoras de seu setor.

Tabela 32 - Perspectiva para 2015

\begin{tabular}{|c|c|c|c|}
\hline \multicolumn{4}{|c|}{$\begin{array}{c}\text { O(a) senhor(a) acha que o livro impresso vai deixar de ser o } \\
\text { principal produto da indústria editorial de livros didáticos } \\
\text { universitários até } 2015 \text { ? Por favor, comente. }\end{array}$} \\
\hline & & Frequência & Percentual \\
\hline \multirow[t]{4}{*}{ Respostas válidas } & Sim & 1 & 3,7 \\
\hline & Não & 14 & 51,9 \\
\hline & Talvez & 10 & 37,0 \\
\hline & Total & 25 & 92,6 \\
\hline Não respondido & & 2 & 7,4 \\
\hline \multicolumn{2}{|l|}{ Total } & 27 & 100,0 \\
\hline
\end{tabular}

Nota-se pelas respostas que os profissionais de editoras não acreditam que a médio prazo o livro impresso deixe de ser o principal produto da indústria editorial de livros didáticos universitários. Apenas 1 respondente acredita que isso acontecerá, enquanto 10 tem dúvidas e uma maioria de 14 acredita que não. 


\section{CONCLUSÕES}

\section{$5.1 \quad$ Objetivo 1}

"O objetivo principal deste trabalho é identificar as diferenças de percepção sobre a adoção de livros didáticos eletrônicos entre professores de ensino superior e profissionais de editoras."

Das 29 variáveis analisadas, 14 tiveram diferença significante entre os profissionais de editoras e professores da USP e do Mackenzie. Na maior parte dessas questões os profissionais discordaram mais das frases.

Os professores percebem várias vantagens de livros eletrônicos sobre os impressos como facilidade de busca e acesso. Havendo mais oferta de livros eletrônicos, eles possivelmente seriam bastante adotados. Mas esse interesse por parte dos professores não é acompanhado de oferta adequada de títulos e modelos de negócio por parte das editoras. Isso porque o temor ao aumento das reproduções não autorizadas de livros eletrônicos, algo que é pouco ou nada relevante para os professores, vem paralisando boa parte do mercado editorial, especialmente o setor de livros didáticos universitários. O temor é tão presente que mesmo em um modelo controlado como a Pasta do Professor, são oferecidos poucos títulos, dificultando sua difusão.

É possível, portanto, que as editoras ${ }^{20}$ (pelo menos de livros universitários) não estejam se preparando adequadamente para uma provável "revolução digital" nos livros à semelhança do que ocorreu na indústria fonográfica.

\section{$5.2 \quad$ Objetivo 2}

"Definir quais os fatores que mais interferem no processo de adoção por professores universitários de livros didáticos eletrônicos.”

\footnotetext{
${ }^{20}$ Apesar de a pesquisa não ter buscado representantes oficiais das editoras, mas sim profissionais das suas equipes, pode-se inferir que as opiniões destes refletem suas estratégias.
} 
O fator que mais interfere no processo de adoção por professores universitários da USP de livros didáticos eletrônicos é uso voluntário, o que mostra o alto grau de liberdade de decisão desse grupo. Em seguida aparece o fator facilidade de uso, o que indica que os professores percebem facilidade de seus alunos com novas tecnologias. No mesmo patamar que o fator anterior, aparece compatibilidade. Isso indica que a percepção de uso de livros eletrônicos é consistente com as experiências passadas dos professores. O resultado desse fator também aponta para uma provável facilidade de adaptação ao uso de livros eletrônicos. Com o mesmo grau de importância aparece demonstração de resultado, o que indica que os resultados da eventual adoção de livros eletrônicos seriam de fácil demonstração.

Num patamar inferior, encontra-se vantagem relativa. Apesar da média mais baixa que esse fator recebeu, deve-se levar em conta que essa é uma inovação que não está sendo utilizada e também é desconhecida de muitos respondentes. Das seis perguntas deste fator, quatro foram baseadas no modelo de Moore e Benbasat (1991), feito normalmente para inovações que vêm sendo utilizadas. As duas perguntas acrescentadas pelo pesquisador tiveram alta concordância, pois se basearam em características mais tangíveis de livros eletrônicos para os respondentes.

Experimentação, apesar da baixa média interfere pouco no processo de adoção. Isso porque os professores já utilizam produtos semelhantes aos livros eletrônicos, que são os artigos científicos.

Imagem e visibilidade são fatores que pouco interferem no processo de adoção por professores universitários de livros didáticos eletrônicos.

Para os professores do Mackenzie, a classificação foi a mesma dos professores da USP, com exceção de uso voluntário, que ficou no patamar mais alto também, juntamente com facilidade de uso, compatibilidade e demonstração de resultado. As conclusões são as mesmas. 


\section{$5.3 \quad$ Objetivo 3}

"Contribuir para o desenvolvimento de uma metodologia de análise das inovações ligadas ao livro impresso."

Por conta do pequeno número de trabalhos científicos encontrados sobre o assunto livro e mais especificamente do livro eletrônico como uma inovação, esta pesquisa não replica nenhum método já utilizado. Não era objetivo inicial desse estudo contribuir para o desenvolvimento de uma metodologia, mas, por conta dessa dificuldade, isso acabou ocorrendo, conforme explicado abaixo.

O primeiro pilar da metodologia utilizada foi classificar o produto livro dentro da indústria de bens informativos. A partir dessa classificação, foi realizado um paralelo entre o produto livro e a música, apresentado as diversas semelhanças e a diferença primordial, a maneira como são consumidos.

O segundo pilar foi apresentar a importância das editoras. Mais do que simples atravessadoras ou intermediárias, elas adicionam valor aos livros. Apesar da facilidade atual de produção de um livro, para que ele consiga realmente circular, editoras são elos fundamentais.

O terceiro foi apresentar o conceito de setorização. Sem essa conceituação, qualquer análise do produto deixa de ter sentido, pois os diversos setores são muito diferentes entre si.

O quarto pilar foi a apresentação do livro eletrônico, que pode alterar profundamente a indústria editorial. Apesar de não haver consenso sobre seu conceito exato, o pesquisador apresenta uma conceituação específica para o mercado brasileiro.

O quinto pilar, adoção de inovação, apresenta a adequação desta pesquisa em se encaixar nos conceitos de Rogers (1995) e a utilização do modelo de Moore e Benbasat (1991).

A partir dos pilares apresentados, pode-se replicar este estudo para diversos outros setores da indústria editorial ou mesmo de outras indústrias de bens informativos. 


\subsection{Conclusões finais}

Alguns pontos do perfil de professores da USP e do Mackenzie devem ser destacados:

- O grupo de professores do Mackenzie é sensivelmente mais jovem, menos experiente e tem menos autores de livros entre os respondentes.

- Os dois grupos indicam com bastante frequência livros didáticos impressos.

- Mais professores do Mackenzie já lidam com livros eletrônicos para trabalho e lazer, conhecem o modelo Pasta do Professor e indicam livros eletrônicos.

- Os dois grupos acreditam que acesso conveniente pela internet, o fato de poder ser vendido em partes e a facilidade de busca são as características mais relevantes de livros eletrônicos para adoção em sala de aula.

Os pontos de destaque no perfil dos profissionais de editoras são:

- Os respondentes são relativamente jovens comparados principalmente com os professores da USP.

- A maior parte já tem em suas empresas experiência com modelos de negócio de venda de livros eletrônicos.

- Acreditam que os principais motivos para não existir oferta variada de títulos em modelos de negócios de livros eletrônicos são: Temor do aumento de reproduções não autorizadas, indefinição quanto ao formato que deve ser oferecido e problemas com a liberação de direitos autorais.

- A maior parte não acredita que o livro impresso deixará de ser o principal produto da indústria editorial de livros didáticos de administração até 2015.

A partir de algumas das constatações acima, talvez se pudesse imaginar que haveria uma diferença grande de percepção a respeito de livros eletrônicos entre os professores da USP e do Mackenzie. Não foi o que ocorreu. Apenas cinco variáveis tiveram diferença significante entre os dois públicos e os fatores acabaram ordenados quase da mesma forma. 
$\mathrm{Na}$ amostra pesquisada, pode-se também notar que as limitações à utilização de livros eletrônicos são muito mais de caráter operacional ${ }^{21}$ do que pedagógico ou de apego ao livro impresso. Além disso, as características consideradas mais relevantes pelos professores para eventual utilização em sala de aula (acesso conveniente, poder ser vendido em partes e facilidade de busca) são vantagens de livros eletrônicos que os impressos não podem oferecer com a mesma qualidade.

Pelas limitações deste trabalho, não se pode concluir que sejam públicos homogêneos ou que professores de administração pensem da mesma maneira em todo o país. No entanto, esse resultado indica que é uma questão de tempo até que livros eletrônicos substituam, pelo menos em parte, os livros impressos nesse segmento.

Foram relatados pelos dois grupos que o questionário os fez pensar sobre diversas utilizações possíveis para livros eletrônicos. Nas respostas, pode-se perceber que os professores, de uma maneira geral, já estão acostumados com a interação digital. Algumas razões são o fato de artigos científicos já serem acessados digitalmente há algum tempo assim como diversas outras fontes de pesquisa, a qualidade de novas ferramentas digitais como celular e a demanda de seus alunos, que cresceram em contato com produtos eletrônicos.

Pelas características da amostra de profissionais das editoras pesquisada, poder-se-ia imaginar que estivessem mais sintonizados com a percepção dos professores sobre livros eletrônicos. Apesar do resultado não ser completamente díspare, foram 14 variáveis que tiveram diferença significante em um total de 29. Por outro lado, a maior parte deles trabalha em empresas que já testam modelos de comercialização de livros eletrônicos, sem resultados importantes até o momento.

Uma das possíveis razões para a falta de resultados até o momento está ligada ao temor dos editores em relação à cópias não autorizadas. Segundo Rodrigo Velloso (2009), os editores querem transplantar para o mundo digital o mesmo modelo de negócios que têm nos livros impressos. A preocupação com reproduções é legitima, mas em um ambiente digital deve

\footnotetext{
${ }^{21}$ Ex.: Diversos professores do Mackenzie comentaram sobre as dificuldades na utilização da "pasta do professor". Foram relatados problemas técnicos, de custo e de falta de disponibilidade de títulos. Isso não foi relatado pelos professores da USP, possivelmente pelo pequeno conhecimento e utilização que têm sobre o sistema.
} 
estar claro para os detentores de conteúdo que ela vai ocorrer. Segundo Kevin Kelly (2009), a internet é uma máquina de cópias gratuitas. E as cópias de livros digitais já existem em profusão com oferta gratuita de diversos títulos em sites no mundo todo (O GLOBO, 2008).

Outro motivo citado pelos profissionais de editoras é a falta de um padrão, como no caso da música. Por conta disso, as editoras têm de oferecer diversos formatos, o que é caro e trabalhoso.

O terceiro motivo mais importante, dificuldades com a liberação de direitos autorais, é cada dia menos relevante na medida em que os autores passam a compreender a importância do digital para a circulação de suas obras. Além disso, boa parte dos autores de livros didáticos de ensino superior não está somente preocupada com o montante de direitos autorais a receber, e sim com a circulação de sua obra. A preocupação maior quanto à perda de receita é das editoras.

Interessante comparar os resultados deste trabalho com pesquisa realizada na Feira de Frankfurt (2008) citada anteriormente. Nela, para um universo de mil respondentes, quatrocentos consideraram que em 2018 a comercialização de livros eletrônicos ultrapassará a de livros impressos. Setenta por cento da amostra afirmou que as empresas nas quais trabalham estão preparadas para os desafios da digitalização, apesar de $60 \%$ não comercializarem livros eletrônicos. As maiores preocupações dos respondentes são direitos autorais, cópias não autorizadas, formato padrão e preço de venda. Apesar da ressalva que esse é um público da indústria do livro e não somente profissionais de editoras de livros didáticos de administração, é interessante notar a semelhança das preocupações.

Outra comparação pertinente é com pesquisa realizada por Levine-Clark (2006) na Universidade de Denver sobre o uso de livros eletrônicos. Metade dos pesquisados (que incluíam professores e estudantes de graduação e pós-graduação) usavam livros eletrônicos. Mais de 50\% dos respondentes usuários de livros eletrônicos destacaram a importância da conveniência e mecanismos de busca. A maior parte (57\%) da amostra não lia todo o livro e sim pedaços, sugerindo que para leituras de grandes trechos provavelmente o livro impresso é uma melhor alternativa. Por fim, apesar da maioria (60\%) demonstrar preferência pelo livro impresso, um número ainda maior $(80 \%)$ indicou um grau de flexibilidade entre os dois formatos. 
Pesquisa de Rowlands et al. (2007) apresenta 44\% de uso de livros eletrônicos entre professores e estudantes de graduação e pós-graduação da University College of London. Desses, $48 \%$ leem os livros na tela, com destaque para a faixa de idade mais jovem, de estudantes de graduação, na qual 59\% o fazem. O propósito da leitura para $71 \%$ dos pesquisados é trabalho ou estudo. Os tipos de livros mais usados em formato eletrônico são os didáticos $(59,9 \%)$ e de referência $(52,4 \%)$. A maior desvantagem do livro eletrônico sobre o impresso é a dificuldade de leitura e as principais vantagens são facilidade de copiar, atualização, economia de espaço e disponibilidade.

Em 2007 foi lançado um suporte para leitura de livros chamado Kindle pela Amazon. O produto apresentava novas funcionalidades em relação a concorrentes como o papel eletrônico (mais agradável para leitura) e possibilidade de realizar transferências de arquivos digitais por conexão sem fio (AMAZON, 2008). O objetivo da empresa era transformar-se no padrão de suporte de livros eletrônico para o mercado americano tendo lançado já em 2009 a segunda versão do aparelho (THE NEW YORK TIMES, 2009). O Google vem digitalizando milhões de livros e vai comercializar acesso a essa base de dados em breve (RODRIGO VELLOSO, 2009). Segundo o site Computerworld (2009), a Apple entrará no mercado de livros eletrônicos em breve com um aparelho semelhante ao Iphone. Esses são apenas alguns exemplos recentes de grandes indústrias de tecnologia que têm interesse no mercado de livros eletrônicos.

Os livros são chamados no mercado de conteúdo de "a última fronteira" por não serem ainda primordialmente distribuídos em formato digital. Isso porque, como visto ao longo dessa pesquisa, diferentemente da música, em que o consumo é feito da mesma maneira, quer seja de um arquivo digital ou analógico, ler um livro impresso é diferente de ler um livro eletrônico. No entanto, o desenvolvimento da tecnologia e as mudanças de hábito (que são, por sua própria natureza, lentas) possivelmente convergirão para uma maior utilização de livros eletrônicos em determinados setores, com diminuição do consumo de livros impressos.

Hoje é simples produzir-se um livro (assim como músicas digitais ou um $\mathrm{CD}$ ). Um pouco mais difícil é distribuí-lo e conseguir boa circulação. O papel das editoras não deve perder a importância desde que elas percebam que não são produtoras de livros impressos, mas sim agregadoras que procuram oferecer o conteúdo mais adequado ao seu público. No formato e 
com a distribuição que melhor convier a este público. De uma maneira ou de outra, livros eletrônicos já são uma realidade e as editoras, principalmente de livros didáticos universitários, se quiserem sobreviver na cadeia de comercialização de livros, precisam se adaptar.

Apesar do exemplo próximo da indústria fonográfica, as editoras não parecem estar prontas para os desafios que a digitalização e a internet vem apresentando. Mas isto não parece se dever a sua falta de visão e sim às dificuldades em se quebrar paradigmas. Ainda mais quando o paradigma a ser quebrado é o de um produto com mais de quinhentos anos.

Se o futuro pertence só aos livros eletrônicos é impossível prever. No entanto, que o futuro pertence também a eles, é um fato que os resultados desta pesquisa apenas reforça. 


\section{REFERÊNCIAS}

ASSOCIAÇÃO BRASILEIRA DE PRODUTORES DE DISCOS - ABPD. Mercado fonográfico brasileiro $2008 . \quad 207, \quad$ Disponível $\quad$ em $<$ http://www.abpd.org.br/noticias_internas.asp?noticia=156>. Acesso em: 03/05/2008.

AMAZON. Kindle. Disponível em <http://www.amazon.com/Kindle-Amazons-WirelessReading-

Device/dp/B000FI73MA/ref=sr_1_1?ie=UTF8\&s=electronics\&qid=1215385075\&sr=8-1>. Acesso em: 06/07/2008.

ANURADHA, K. T.; USHA, H. S. Use of e-books in an academic and research environment Eletronic library and information systems, v. 40, n. 1, p. 48-62, 2006.

BECKETT, John, The effect of a new version of software on its use: A case study of a course management system. Dissertation in Nova Southeastern University, 2007.

BORGMAN, Christine L. Borgman Scholarship in the digital age: information, infrastructure and the internet. Massachusets: The Mit Press, 2007.

BUNELLE, J. The e-book: Future or fad. Missipi Libraries, n. 64, p. 3-6, 2000.

BURK, Roberta. E-book devices and the marketplace: in search of customers. Bradford: Library High Tech, 2001.

CÂMARA BRASILEIRA DO LIVRO/ FUNDAÇÃO JOÃO PINHEIRO - CBL. Diagnóstico do setor editorial brasileiro. Pesquisa Anual. Ed. 1990 a 2003.

CARVALHO, Kátia de. O admirável mundo da informação e do conhecimento: Livro impresso em papel e livro eletrônico. Revista de Bibliotecologia y Ciencias de la informácion, abril-junio, año/v. 7, n. 024, 2006.

CASTELLS, Manuel A sociedade em rede. Rio de Janeiro: Paz e Terra, 1999.

CENTRO DE ESTUDOS DA TECNOLOGIA DA INFORMAÇÃO E COMUNICAÇÃO CETIC. Pesquisa Tic domicílios 2007. 2007. Disponível em $<$ http://www.cetic.br/usuarios/tic/2007/index.htm>. Acesso em: 20/05/2008.

CHARTIER, Roger. A aventura do livro: do leitor ao navegador. São Paulo: Editora Unesp, 1998.

Les métamorphoses du livre: Les rendez-vous de l'edition: le livre et le numérique.

Prais : Bpi/Centre Pompidou, 2001.

COLLINS, Jill; HUSSEY, Roger. Pesquisas em administração. 2. ed. Porto Alegre: Bookman, 2005.

COMPUTERWORLD. Elgan: Here comes the e-book revolution. Disponível em $<$ http://www.computerworld.com/action/article.do?command=viewArticleBasic\&taxonomyN 
ame $=$ Mobile + and + Wireless\&articleId=9127538\&taxonomyId $=15 \&$ pageNumber $=1>$. Acesso em: 19/02/2009.

COPE, B.; KALANTZIS, D. Print and eletronic text convergence. Altona: Common Ground Pub, 2001.

COSTA FILHO, Bento Alves; PIRES, Pericles José; HERNANDEZ, José Mauro da Costa. Modelo Tecnholovy Acceptance Model - Tam aplicado aos automated teller machines - Atm's.

RAI - Revista de Administração e Inovação. São Paulo, v. 4, n. 1, p. 40-56, 2007.

CHRISTENSEN, Clayton M.; BOWER, Joseph L. Disruptive Technologies: Catching the wave. Harvard Business Review, Boston, Jan.-Feb. 1995.

CRAWSHAW, Amy B. Electronic textbook technology in the classroom. In: Encyclopedia of information technology curriculum integration Lawrence H. Tomei. Information Science Reference, p. 275-277, 2008.

CROWSTON, Kevin; MYERS, Michael D. Information tecnhology and the transformation of industries: three research perspectives. Journal os strategic information systems, v. 13, p. 528, 2004.

DUBINI, P. Voltare Pagina: Economia e gestione strategica nel settore dell'editoria libraria. 2. ed. Milano: Etas Libri, 2001. In: FURTADO, José Afonso. Metamorfoses na era digital. 2004. I Seminário Brasileiro Sobre o Livro e História Editorial. Rio de Janeiro, UFF, Casa de Rui Barbosa, 8-11 de novembro de 2004.

ÉPOCA. Livros mais vendidos. Editora Globo, ano 11, n 565, 14/03/2009.

EPSTEIN, Jason. O negócio do livro. Rio de Janeiro: Record, 2002.

FUNDAÇÃO INSTITUTO DE PESQUISAS ECONÔMICAS - FIPE. Produção e vendas do setor editorial brasileiro. Pesquisa Anual. Ed. 2004 a 2007.

FRANCESCHINI, A. Retrato da leitura no Brasil: Análises de mercado. São Paulo: ABDR, 2001.

O estudante universitário e as cópias de textos e materiais para estudo. Análises de mercado. ABDR, 2002.

FOLHA DE S.PAULO. Livros mais vendidos. São Paulo, ano 89, n. 29.200, 14/03/2009.

FRANKFURT BOOK FAIR. Survey 2007. Disponível em: $<$ http://www.buchmesse.de/en/index.php?content=/en/presse_pr/newsletter/container/content/ 16061/content.html> Acesso em 21/04/2008.

. Survey 2008. Disponível em: <https://en.book-

fair.com/fbf/journalists/press_releases/fbf/detail.aspx?c20f0587-85d5-44d3-a9a4-

eb75d0c6143b=ec26a4d2-9b2d-499d-8a3f-3e94b5cf6bff >. Acesso em: 22/11/2008. 
FURTADO, José Afonso. Metamorfoses na era digital. I Seminário Brasileiro Sobre o Livro e História Editorial. Rio de Janeiro, UFF, Casa de Rui Barbosa, 8-11 de novembro de 2004.

GALL, James E. Dispelling Five Myths about E-books. Information Technology and libraries, v. 24, n. 1, p. 25-31, Mar. 2005.

GIBSON, Matthew; RUOTOLO, Christine. Beyond the web: Tei, the digital library and the Ebook revolution. Computer and humanities, n. 37, p. 57-63, 2003.

GOMEZ, Jeff. Print is dead. New York: Macmilam, 2008.

GORDON, Steve. The future of the music business: how to succeed with the new digital technologies. São Francisco: Backbeat Books, 2005.

GUNTER, Barrie. Eletronic books: a survey of users in UK. Aslib Proceedings: New information perspectives, v. 57, n. 6, 2005.

HAGE, Ellen V. E-book technology: the relationship between self efficacy and usage levels across gender and age. PH.D dissertation in philosophy Capella University, 2005.

HERTHER, Nancy. The e-book industry today: a bumpy road becomes an evolutionary path to market maturity. The eletronic library, v. 23, n. 1, p. 45-53, 2005.

HIPÓLITO, J. A. M. et al. Como Usar a Internet em Pesquisa. In: I Semead - Seminários em Administração Programa de Pós-Graduação em Administração, FEA-USP. São Paulo, 15-16 de outubro de 1996.

INSTITUTO BRASILEIRO DE GEOGRAFIA E ESTATÍSTICA - IBGE. Pesquisa nacional por amostra de domicílio, 2005.

INSTITUTO BRASILEIRO DE OPINIÃO PÚBLICA E ESTATÍSTICA - IBOPE / NETRATINGS, 2007. Disponível em <www.ibope.com.br> . Acesso em: 05/02/2008.

INSTITUTO BRASILEIRO DE OPINIÃO PÚBLICA E ESTATÍSTICA - IBOPE /NETRATINGS, 2009. Disponível em <www.ibope.com.br> . Acesso em: 05/03/2009.

ILLIE, Virginia et al. Gender differences in perceptions and use of communication technologies: A diffusion of innovation approach. Information Resources Management Journal. Hershey, v. 18, n. 3, Jul.-Sep. 2005.

INSTITUTO PRÓ-LIVRO. Retratos da leitura no Brasil. 2008. Disponível em $<$ http://www.prolivro.org.br/ipl/publier4.0/dados/anexos/48.pdf>. Acesso em: 13/05/2008.

IPSOS INSIGHT. Mercado de música na internet 2006. Disponível em <http://www.abpd.org.br/musicaInternet_pesquisa.asp>. Acesso em: 03/05/2008.

ISTOÉ. Livros mais vendidos. São Paulo: Editora Três, ano 32, n 2.053, 18/03/2009. 
KALLIAREKOS, Kosmo et al. Do you know where your book publishing business is? Publishing Research Quarterly, v. 20, Issue 4, p. 14-22, winter 2005.

KASDORF, William E. The Columbia guide to digital publishing. Nova York: Columbia University Press, 2003.

KESTNER, R. Neil. The changing landscape of academics as affected by new communications technology. In: Transition from paper. Chicago: American academy of arts \& sciences, 2001a.

The future of science textbooks In: Transition from paper. Chicago: American academy of arts \& sciences, 2001b.

KELLY, Kevin. Better than free. Disponível em $<$ http://www.kk.org/thetechnium/archives/2008/01/better_than_fre.php >. Acesso em: 26/03/ 2009.

KLEEGE, Georgina. Visible Braille/Invisible Blindness. Journal of Visual Culture, v. 5, n. 209, 2006.

KUSEK, David; LEONHARD, Gerd. The future of music: Manifesto for the digital music revolution. Boston: Berklee Press, 2005.

LEVINE-CLARK, Michael. Eletronic Book Usage: A survey at the University of Denver. Project Muse Scholarly Journals online, v. 6, n. 3, julho 2006.

LIEBOWITZ, Stan. Rethinking the network economy: the true forces that drive the digital marketplace. New York: Amacon, 2002.

LIVRARIA CULTURA. Livros mais vendidos. Disponível em <http://www.livrariacultura.com.br>. Acesso em: 08/09/2008.

LOURENÇO, Mariana Simões. Edição digital: aspectos e perspectivas da produção de ebooks no 2004.2 Brasil. 200 Disponível <http://www.livroehistoriaeditorial.pro.br/pdf/marianasimoes.pdf>. Acesso em: 15/05/2008.

LYNCH, Clifford. The battle to define the future of the book in the digital world. First Monday. 2001. Disponível em <http://www.firstmonday.org/issues/issue6_6/lynch/\#12>. Acesso em: 26/04/2008.

MARCOVITCH, Jacques. A informação e o conhecimento. São Paulo em perspectiva. São Paulo, n.16, v. 4, 2002.

MARQUES, I. C. Desmaterialização e Trabalho. In: LASTRES, Helena; ALBAGLI, Sarita. (Org.). Informação e Globalização na Era do Conhecimento. Rio de Janeiro: Campus, 1999, p. 191-215.

MARTYNS, Daniel. Brave New Wold. Digitisation of content: The opportunities for booksellers and the booksellers association. The booksellers association of the United Kingdom and Ireland, 2006. 
MATTAR, Fauze N. Pesquisa de marketing. 4. ed. São Paulo: Atlas, 1996.

MINISTÉRIO DA EDUCAÇÃO E CULTURA - MEC; INSTITUTO NACIONAL DE ESTUDOS E PESQUISAS EDUCACIONAIS - INEP. Senso da educação superior 2006, DisponÍvel em <http://www.inep.gov.br/superior/censosuperior/default.asp> Acesso em: 02/05/2007.

MELLO, Marco Antônio Machado Ferreira. O comércio eletrônico e as novas formas de informação: Do livro convencional ao livro eletrônico (ebook). Dissertação de mestrado apresentada ao curso de Pós-graduação em Engenharia de produção da UFSC, 2002.

MCLUHAN, Marshal. A galáxia de Gutenberg. 2. ed. São Paulo: Companhia Editora Nacional, 1977.

MICHAELIS. Disponível em <http://michaelis.uol.com.br/moderno/portugues/index.php> Acesso em: 29/06/2008.

MOORE, Gary C.; BENBASAT, Izak. Development of an instrument to measure the perceptions of adopting an information technology innovation. Information Systems Research, v. 2, n. 3, 1991.

O ESTAdo DE SÃo PAULO. Livros mais vendidos. São Paulo, ano 131, n 42.155, 14/03/2009.

O GLOBO. Livros mais vendidos. Rio de Janeiro, ano 85, n 27.613, 14/03/2009.

O GLOBO. Livros-texto estão sendo pirateados. Rio de Janeiro, ano 84, 21/07/2008.

ORLIKOWSKI, Wanda J.; BARLEI, Stephen R. Technology and institutions: what can research on information technology and research on organizations learn from each other? Mis quarterly, v. 25, n. 2, p. 145-165, june 2001.

PASTA DO PROFESSOR. Disponível em <http://www.pastadoprofessor.com.br> Acesso em: 19/04/2008.

PEREZ, Gilberto. Adoção de inovações tecnológicas: um estudo sobre o uso de sistemas de informação na área de saúde. Tese de doutorado apresentada à FEA-USP, 2006.

PINSONNEAULT, A.; KRAMER, K. L. Survey research in management information systems: an assessement. Journal of Management Information System, Paper 83, 1993.

PORTER, Michael E. Vantagem competitiva. 27. ed. São Paulo: Campus, 1989.

; MILLAR, Victor E. How information gives you competitive advantage. Harvard

Business Review, Boston, Jul.-Ago. 1985.

PUBLISHERS ASSOCIATION - UK. Book publishing industry statistics. London, 2005.

QUINT, Barbara. Why isn't print dead...yet? Information Today Medford Iss 1, p. 7, jan. 
2008.

RAO, Siriginidini Subba. Familiarization of eletronic books. The eletronic library, v. 19, n. 4, p. 247-256, 2001.

. Eletronic books: their integration into library and information centers. The eletronic library, v. 23, n. 1, p. 116-140, 2005.

RECORD INDUSTRY ASSOCIATION OF AMERICA - RIAA. 2007 Year end market report on U.S. reported music shipment. Disponível em <http://76.74.24.142/81128FFD028F-282E-1CE5-FDBF16A46388.pdf> Acesso em: 02/05/2008.

RIFKIN, Jeremy. A Era do acesso. São Paulo: Makron Books, 2001.

ROGERS, Everett M. Diffusion of Innovations. 5. ed. New York: Free Press, 1995 (4. ed.) e 2003 (5. ed.).

ROWLANDS, David Nicholas; JAMALI, Hamid R.; HUNTINGTON, Paulo. What do faculty and students really think about e-books? Ciber Universiry College London, 2007. Disponível em <http://www.homepages.ucl.ac.uk/ uczciro/findings.pdf>, Acesso em: 01/03/ 2009.

ROSA, Flávia Goulart Garcia. Pasta do Professor o uso de cópias nas universidades. Salvador: Edufba, 2007.

SAMPIERI, Roberto Hernández; COLLADO, Carlos Fernández; LUCIO, Pilar Baptista Metodologia de pesquisa. 3. ed. São Paulo: McGrawHill, 2006.

SARAIVA. Livros mais vendidos. Disponível em <www.saraiva.com.br> Acesso em: 08/09/2008.

SHAPIRO, C.; VARIAN, H. R. Economia da informação. 9. ed. São Paulo: Campus, 2003.

SHAVER, Dan; SHAVER, Mary Alice. Books and digital technology: a new industrial model Journal of media economics, v. 16, n. 2, p. 71-86, 2003.

TAPSCOTT, Don. The digital economy: Promise and peril in the age of networked intelligence. New York: McGraw Hill, 1996.

TAYLOR, Alasdair. Publishing and eletronic piracy. Learned Publishing, v. 19, p. 168-174, 2006.

TAYLOR, David. Never mind the textbook - here's the chapters Learned Publishing, n. 14, p. 107-112, 2001.

THE NEW YORK TIMES. Amazon in big push for new Kindle Model. Disponível em <http://www.nytimes.com:80/2009/02/10/technology/personaltech/10kindle.html?_r=1\&nl=te ch\&emc=techa1 > Acesso em: 19/02/2009. 
THOMPSON, John B. Books in the digital age. Cambridge: Polity Press, 2005. UNITED NATIONS EDUCATIONAL, SCIENTIFIC AND CULTURAL ORGANIZATION - UNESCO. Institute for statistics. Book production. Disponível em $<$ http://www.uis.unesco.org/ev.php?ID=5096_201\&ID2=DO_TOPIC > Acesso em: 02/05/2008.

VALOR ECONÔMICO. Base de internautas pode superar 50 milhões. São Paulo, 06/01/2009.

VEJA. Livros mais vendidos. São Paulo: Editora Abril, ano 42, ed. 2.104,18/03/2009.

VELLOSO, Rodrigo Entrevista concedida a Daniel Pinsky. São Paulo, 26 mar. 2009.

WEIBLE, Rick; WALLACE, John. Cyber research: The impact of the internet on data collection. Marketing Research. Chicago, v.10, n.3, p. 19-24, Fall 1998.

ZIKMUND, William G. Business Research Methods. 7. ed. Mason: Thomson Learning, 2003.

ZOGBY INTERNATIONAL. The reading and book buying habits of americans, 2008. Disponível em <http://www.zogby.com/random\%20house\%20final\%20report.pdf>. Acesso em: $15 / 08 / 2008$. 


\section{APÊNDICES}

APÊNDICE 1 - QUESTIONÁRIO PROFESSORES/PROFISSIONAIS APRESENTADO AOS ESPECIALISTAS

APÊNDICE 2 - QUESTIONÁRIO PROFESSORES/PROFISSIONAIS

APÊNDICE 3 - MÉDIAS, DESVIOS PADRÃO E INTERVALOS DE CONFIANÇA DAS VARIÁVEIS

APÊNDICE 4 - ALTERNATIVAS À COMERCIALIZAÇÃO DO LIVRO IMPRESSO, UTILIZANDO-SE

TECNOLOGIAS LIGADAS À DIGITALIZAÇÃO E/OU À INTERNET

APÊNDICE 5 - A PASTA DO PROFESSOR

APÊNDICE 6 - LISTA DAS EDITORAS ANALISADAS

APÊNDICE 7 - MÉDIAS, DESVIOS PADRÃO E INTERVALOS DE CONFIANÇA DOS FATORES

APÊNDICE 8 - MINICURRÍCULO DOS ESPECIALISTAS

APÊNDICE 9 - ENTREVISTAS 


\section{APÊNDICE 1 - QUESTIONÁRIO PROFESSORES/PROFISSIONAIS}

\section{APRESENTADO AOS ESPECIALISTAS.}

Não constam deste item as afirmações que foram retiradas do questionário final por sugestão dos especialistas.

Professores

1- Nome

2- Idade

3- Professor(a) da área de

$\square$ Recursos humanos

Economia das organizações

Métodos quantitativos e informática

Operações

Finanças

Outra(s). Por favor, especifique:

Administração geral

Marketing

4- Há quanto tempo leciona no ensino superior?

Até 10 anos

Entre 11 e 25 anos

Mais de 25 anos

5- Número de alunos no segundo semestre de 2008:

Obs.: Levar em conta somente os alunos do Mackenzie ou da FEA/USP

$\square$ Até 100

$\square$ Entre 101 e 200

Entre 201 e 300

Mais de 300

6- Período no qual leciona:

Obs.: Levar em conta somente as aulas ministradas no Mackenzie ou na FEA/USP

Noturno $\square$ Diurno

7- $\mathrm{O}$ (A) senhor(a) tem livros publicados (como autor(a), organizador(a) ou co-autor(a))?

Sim

Não

8- O(A) senhor(a) indica livros para leitura obrigatória nas matérias que leciona?

Sim

Não

Eventualmente

Profissionais

1- Nome

2- Empresa na qual trabalha

3- Profissional da área $\square$ Comercial $\square$ Editorial $\square$ Ambas

Outra. Favor informar

4- Idade

5- Tempo como profissional do setor editorial de livros didáticos de ensino superior:

Até 10 anos 
Entre 10 e 25 anos

Mais de 25 anos

Com relação à utilização de livros eletrônicos como material didático, por favor, leia a definição abaixo e responda:

Livro eletrônico: É um livro digital em arquivo texto ou sonoro que pode ser:

- Vendido (ou disponibilizado) na íntegra ou em partes

- Alugado (por acesso pago on-line por determinado período de tempo)

- Vendido por capítulos gerados de arquivo digital, mas impressos para o consumidor em um ponto de venda (Pasta do Professor).

Nesse sentido o importante não é como o livro será consumido (lido ou ouvido), mas sim como saiu da editora para ser comercializado.

Professores

9 - O(A) senhor(a) já utilizou livros eletrônicos para fins de trabalho ou lazer?

Sim

Não

10 - O(A) senhor(a) indica ou já indicou livros eletrônicos para seus alunos de graduação?

$\square \operatorname{Sim}$

$\square$ Não

11- O(A) senhor(a) conhece o modelo de negócio para venda de livros por capítulos impressos chamado "Pasta do Professor"?

$\square \operatorname{Sim}$

Não

Profissionais

6- A empresa na qual trabalha comercializa livros eletrônicos?

$\square \operatorname{Sim}$

$\square$ Não

7- Em caso positivo, que modelo de comercialização utiliza?

Próprio

Pasta do Professor

Outro. Favor especificar

8- Quais são os principais motivos para não existir oferta variada de títulos em modelos de negócio de livros eletrônicos? (marcar quantas alternativas quiser)

$\square$ Temor das editoras de que haja aumento de reproduções não autorizadas

$\square$ Problemas das editoras com a liberação de direitos autorais

$\square$ Falta de interesse das editoras, não sei o motivo.

$\square$ Falta de interesse do consumidor

Indefinição quanto ao formato digital em que deve ser oferecido

Outro(s) motivo(s). Qual(is)?

9- $\mathrm{O}$ (A) senhor(a) acha que o livro impresso vai deixar de ser o principal produto da indústria editorial de livros didáticos universitários até 2015? Por favor, comente.

$\square \operatorname{Sim}$ 
Não

Talvez

DT - Discordo totalmente

D - Discordo

NCND - Nem concordo, nem discordo

$\mathrm{C}$ - Concordo

CT - Concordo totalmente

Vantagem relativa

Grau com o qual uma inovação é percebida como melhor que as precursoras

\begin{tabular}{|l|l|l|l|l|l|}
\hline Professores & DT & D & NCND & C & CT \\
\hline $\begin{array}{l}\text { Utilizar livros eletrônicos faria com que os } \\
\text { alunos tivessem acesso mais rápido à } \\
\text { bibliografia do curso }\end{array}$ & & & & & \\
\hline $\begin{array}{l}\text { Indicar livros eletrônicos aumentaria a } \\
\text { eficiência do meu trabalho }\end{array}$ & & & & & \\
\hline $\begin{array}{l}\text { Se eu indicasse livros eletrônicos teria maior } \\
\text { controle sobre o meu trabalho }\end{array}$ & & & & & \\
\hline $\begin{array}{l}\text { Indicar livros eletrônicos aumentaria minha } \\
\text { produtividade }\end{array}$ & & & & & \\
\hline $\begin{array}{l}\text { Eu indicaria livros eletrônicos caso fossem mais } \\
\text { baratos que os impressos }\end{array}$ & & & & & \\
\hline $\begin{array}{l}\text { Eu indicaria livros eletrônicos caso fossem } \\
\text { vendidos em partes }\end{array}$ & & & & & \\
\hline
\end{tabular}

\begin{tabular}{|l|l|l|l|l|l|}
\hline Profissionais & DT & D & NCND & C & CT \\
\hline $\begin{array}{l}\text { Os professores consideram que utilizar livros } \\
\text { eletrônicos faria com que os alunos tivessem } \\
\text { acesso mais rápido à bibliografia do curso }\end{array}$ & & & & & \\
\hline $\begin{array}{l}\text { Indicar livros eletrônicos aumentaria a eficiência } \\
\text { do trabalho dos professores }\end{array}$ & & & & & \\
\hline $\begin{array}{l}\text { Indicar livros eletrônicos daria maior controle aos } \\
\text { professores sobre o seu trabalho }\end{array}$ & & & & & \\
\hline $\begin{array}{l}\text { Indicar livros eletrônicos aumentaria a } \\
\text { produtividade dos professores }\end{array}$ & & & & & \\
\hline $\begin{array}{l}\text { Os professores indicariam livros eletrônicos caso } \\
\text { fossem mais baratos do que os impressos }\end{array}$ & & & & & \\
\hline $\begin{array}{l}\text { Os professores indicariam livros eletrônicos caso } \\
\text { fossem vendidos em partes }\end{array}$ & & & & & \\
\hline
\end{tabular}

Compatibilidade

Grau com o qual a inovação é percebida como consistente com valores existentes, necessidades e experiências passadas dos adotantes potenciais. 


\begin{tabular}{|l|l|l|l|l|l|}
\hline Professores & DT & D & NCND & C & CT \\
\hline $\begin{array}{l}\text { Indicar livros eletrônicos se encaixaria bem no meu } \\
\text { estilo de trabalho }\end{array}$ & & & & & \\
\hline
\end{tabular}

\begin{tabular}{|l|l|l|l|l|l|}
\hline Profissionais & DT & D & NCND & C & CT \\
\hline $\begin{array}{l}\text { Indicar livros eletrônicos se encaixaria bem no estilo } \\
\text { de trabalho dos professores }\end{array}$ & & & & & \\
\hline
\end{tabular}

Experimentação

Grau com o qual uma inovação pode ser experimentada antes de sua adoção.

\begin{tabular}{|l|l|l|l|l|l|}
\hline Professores & DT & D & NCND & C & CT \\
\hline $\begin{array}{l}\text { Já tive diversas oportunidades de testar o uso de } \\
\text { livros eletrônicos com meus alunos. }\end{array}$ & & & & & \\
\hline $\begin{array}{l}\text { Eu sei onde posso encontrar livros eletrônicos para } \\
\text { testá-los de maneira satisfatória }\end{array}$ & & & & & \\
\hline $\begin{array}{l}\text { Livros eletrônicos estão disponíveis para que eu } \\
\text { possa testá-los adequadamente }\end{array}$ & & & & & \\
\hline $\begin{array}{l}\text { Eu não tenho oportunidades adequadas para testar os } \\
\text { diferentes usos de um livro eletrônico }\end{array}$ & & & & & \\
\hline $\begin{array}{l}\text { Uma tentativa real de testar os vários usos do livro } \\
\text { eletrônico no dia a dia não é possível }\end{array}$ & & & & & \\
\hline $\begin{array}{l}\text { Existem poucos títulos de livros eletrônicos } \\
\text { disponíveis, o que dificulta a sua indicação. }\end{array}$ & & & & & \\
\hline
\end{tabular}

\begin{tabular}{|l|l|l|l|l|l|}
\hline Profissionais & DT & D & NCND & C & CT \\
\hline $\begin{array}{l}\text { Os professores têm diversas oportunidades de testar } \\
\text { o uso de livros eletrônicos com seus alunos }\end{array}$ & & & & & \\
\hline $\begin{array}{l}\text { Os professores sabem onde encontrar livros } \\
\text { eletrônicos para poder testá-los de maneira } \\
\text { satisfatória. }\end{array}$ & & & & & \\
\hline $\begin{array}{l}\text { Os professores têm à disposição livros eletrônicos } \\
\text { para poder testá-los adequadamente. }\end{array}$ & & & & & \\
\hline $\begin{array}{l}\text { Os professores não têm oportunidades adequadas } \\
\text { para testar os diferentes usos de um livro eletrônico }\end{array}$ & & & & & \\
\hline $\begin{array}{l}\text { Para os professores não é possível testar os vários } \\
\text { usos do livro eletrônico de maneira real no seu dia a } \\
\text { dia }\end{array}$ & & & & & \\
\hline $\begin{array}{l}\text { Por existirem poucos títulos de livros eletrônicos } \\
\text { disponíveis, os professores têm dificuldade em } \\
\text { indicá-los. }\end{array}$ & & & & & \\
\hline
\end{tabular}

Facilidade de uso

Grau com o qual uma inovação é percebida como fácil de usar.

\begin{tabular}{|l|l|l|l|l|l|}
\hline Professores & DT & D & NCND & C & CT \\
\hline $\begin{array}{l}\text { Acredito que a utilização de livros eletrônicos seria } \\
\text { incômoda para meus alunos }\end{array}$ & & & & & \\
\hline
\end{tabular}




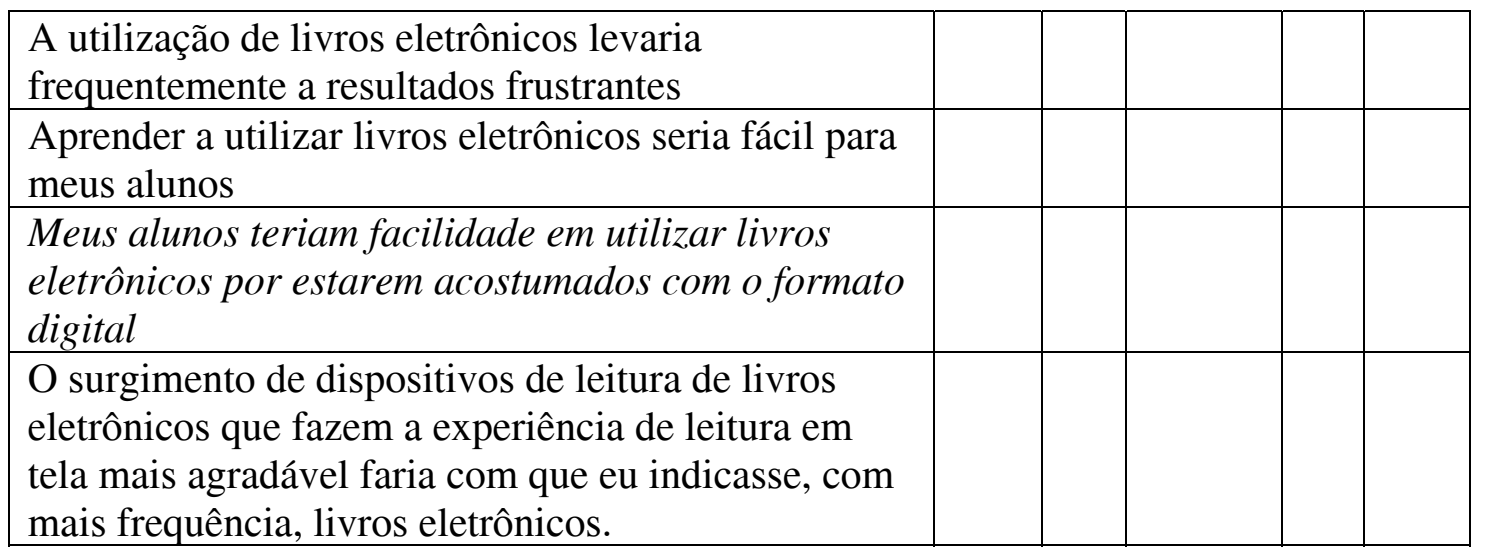

\begin{tabular}{|c|c|c|c|c|c|}
\hline \multirow{2}{*}{$\begin{array}{l}\text { Profissionais } \\
\text { Os professores acreditam que seria incômodo para } \\
\text { seus alunos o uso de livros eletrônicos }\end{array}$} & DT & $\mathrm{D}$ & NCND & $\mathrm{C}$ & $\mathrm{CT}$ \\
\hline & & & & & \\
\hline $\begin{array}{l}\text { Os professores consideram que o uso de livros } \\
\text { eletrônicos levaria, frequentemente, a resultados } \\
\text { frustrantes }\end{array}$ & & & & & \\
\hline $\begin{array}{l}\text { Os professores acreditam que seria fácil para seus } \\
\text { alunos aprender a utilizar livros eletrônicos }\end{array}$ & & & & & \\
\hline $\begin{array}{l}\text { Os professores acreditam que seus alunos teriam } \\
\text { facilidade de utilizar livros eletrônicos por estarem } \\
\text { acostumados com o formato digital }\end{array}$ & & & & & \\
\hline $\begin{array}{l}\text { O surgimento de dispositivos de leitura de livros } \\
\text { eletrônicos que fazem a experiência de leitura em } \\
\text { tela mais agradável fará com que os professores } \\
\text { indiquem, com mais frequência, livros eletrônicos. }\end{array}$ & & & & & \\
\hline
\end{tabular}

\section{Imagem}

Grau com o qual o uso de uma inovação é percebido para melhorar a imagem de um indivíduo.

\begin{tabular}{|l|l|l|l|l|l|}
\hline Professores & DT & D & NCND & C & CT \\
\hline $\begin{array}{l}\text { A indicação de livros eletrônicos para meus alunos } \\
\text { seria vista com bons olhos pela comunidade }\end{array}$ & & & & & \\
acadêmica & & & & & \\
\hline $\begin{array}{l}\text { Professores que indicassem livros eletrônicos teriam } \\
\text { mais prestígio do que aqueles que não indicassem }\end{array}$ & & & & & \\
\hline
\end{tabular}

\begin{tabular}{|l|l|l|l|l|l|}
\hline Profissionais & DT & D & NCND & C & CT \\
\hline $\begin{array}{l}\text { Os professores consideram que indicar a utilização } \\
\text { de livros eletrônicos seria visto com bons olhos pela } \\
\text { comunidade acadêmica }\end{array}$ & & & & & \\
\hline $\begin{array}{l}\text { Professores que indicassem livros eletrônicos teriam } \\
\text { mais prestígio do que aqueles que não indicassem. }\end{array}$ & & & & & \\
\hline
\end{tabular}

Uso voluntário

O grau com o qual o uso da inovação é percebido como voluntário ou espontâneo. 


\begin{tabular}{|l|l|l|l|l|l|}
\hline Professores & DT & D & NCND & C & CT \\
\hline $\begin{array}{l}\text { Meus chefes esperam que eu indique livros } \\
\text { eletrônicos }\end{array}$ & & & & & \\
\hline A indicação de livros eletrônicos é voluntária & & & & & \\
\hline $\begin{array}{l}\text { Apesar de ser possivelmente positivo, indicar livros } \\
\text { eletrônicos não é obrigatório em meu trabalho }\end{array}$ & & & & & \\
\hline
\end{tabular}

\begin{tabular}{|l|l|l|l|l|l|}
\hline Profissionais & DT & D & NCND & C & CT \\
\hline $\begin{array}{l}\text { Os chefes dos professores esperam que eles } \\
\text { indiquem livros eletrônicos }\end{array}$ & & & & & \\
\hline A indicação de livros eletrônicos é voluntária & & & & & \\
\hline $\begin{array}{l}\text { Apesar de ser possivelmente positivo, indicar livros } \\
\text { eletrônicos não é obrigatório para os professores }\end{array}$ & & & & & \\
\hline
\end{tabular}

\section{Visibilidade}

O grau com o qual uma inovação se torna visível para indivíduos ou grupos de uma organização.

\begin{tabular}{|l|l|l|l|l|l|}
\hline Professores & DT & D & NCND & C & CT \\
\hline $\begin{array}{l}\text { Tenho visto o trabalho que outros professores } \\
\text { desenvolvem com a indicação de livros eletrônicos }\end{array}$ & & & & & \\
\hline $\begin{array}{l}\text { Na faculdade onde leciono, diversos professores } \\
\text { indicam livros eletrônicos }\end{array}$ & & & & & \\
\hline $\begin{array}{l}\text { É fácil observar outros utilizando livros eletrônicos } \\
\text { na faculdade }\end{array}$ & & & & & \\
\hline
\end{tabular}

\begin{tabular}{|l|l|l|l|l|l|}
\hline Profissionais & DT & D & NCND & C & CT \\
\hline $\begin{array}{l}\text { Os professores têm como ver que tipo de trabalho } \\
\text { seus colegas desenvolvem quando indicam livros } \\
\text { eletrônicos }\end{array}$ & & & & & \\
\hline Diversos professores indicam livros eletrônicos & & & & & \\
\hline $\begin{array}{l}\text { É fácil para professores observar outros utilizando } \\
\text { livros eletrônicos nas faculdades }\end{array}$ & & & & & \\
\hline
\end{tabular}

Demonstração de resultados

Tangibilidade dos resultados pelo uso da inovação.

\begin{tabular}{|l|l|l|l|l|l|}
\hline Professores & DT & D & NCND & C & CT \\
\hline $\begin{array}{l}\text { Eu não teria dificuldade alguma em comunicar a } \\
\text { outros os resultados da indicação de livros } \\
\text { eletrônicos }\end{array}$ & & & & & \\
\hline $\begin{array}{l}\text { Acredito que poderia comunicar a outros as } \\
\text { consequências da indicação de livros eletrônicos }\end{array}$ & & & & & \\
\hline $\begin{array}{l}\text { Os resultados da utilização do livro eletrônico seriam } \\
\text { claros para mim }\end{array}$ & & & & & \\
\hline
\end{tabular}




\begin{tabular}{|l|l|l|l|l|l|}
\hline Profissionais & DT & D & NCND & C & CT \\
\hline $\begin{array}{l}\text { Não seria difícil para um professor comunicar os } \\
\text { resultados do uso de livros eletrônicos }\end{array}$ & & & & & \\
\hline $\begin{array}{l}\text { Os professores poderiam comunicar as } \\
\text { consequências da indicação de livros eletrônicos }\end{array}$ & & & & & \\
\hline $\begin{array}{l}\text { Os resultados da utilização de livros eletrônicos } \\
\text { seriam claros para o professor }\end{array}$ & & & & & \\
\hline
\end{tabular}

\section{Professores}

12- Qual(is) as característica(s) de livros eletrônicos listadas abaixo o(a) senhor(a) considera como vantagens relevantes para uma eventual utilização em sala de aula como material pedagógico?

Obs.: Marcar quantas alternativas quiser

As cópias são perfeitas

Acesso conveniente pela internet 24 horas por dia

Possibilidade de alterar o tamanho e tipo das fontes

Facilidade de busca

Podem ser vendidos em partes

Podem ser atualizados a qualquer momento

Podem ser conectados por meio de hipertexto (links)

Podem oferecer arquivos sonoros

Podem oferecer informação multimídia

Podem ser carregados em pequenos dispositivos

Nenhuma

Outra(s). Por favor, especifique

13- Havendo algum comentário que deseje fazer, por favor, escreva abaixo:

\section{Profissionais}

10 - Havendo algum comentário que deseje fazer, por favor, escreva abaixo: 


\section{APÊNDICE 2 - QUESTIONÁRIO PROFESSORES/PROFISSIONAIS}

Professores

1- Nome

2- Idade

3- Professor(a) da área de

Recursos humanos

Métodos quantitativos e informática

Economia das organizações

Finanças

Administração geral

Marketing

4- Há quanto tempo leciona no ensino superior?

Até 10 anos

Entre 11 e 25 anos

Mais de 25 anos

5- Número de alunos no segundo semestre de 2008:

Obs.: Levar em conta somente os alunos do Mackenzie ou da FEA/Usp

Até 100

Entre 101 e 200

Entre 201 e 300

Mais de 300

6- Período no qual leciona:

Obs.: Levar em conta somente as aulas ministradas no Mackenzie ou na FEA/Usp

$\square$ Noturno $\square$ Diurno

7- $\mathrm{O}(\mathrm{A})$ senhor(a) tem livros publicados (como autor(a), organizador(a) ou co-autor(a))?

Sim

Não

8- $\mathrm{O}$ (A) senhor(a) indica livros para leitura obrigatória nas matérias que leciona?

Sim

Não

Eventualmente

Profissionais

1- Nome

2- Empresa na qual trabalha

3- Profissional da área $\square$ Comercial $\square$ Editorial $\square$ Ambas

Outra. Favor informar

4- Idade

5- Tempo como profissional do setor editorial de livros didáticos de ensino superior:

Até 10 anos

Entre 10 e 25 anos

Mais de 25 anos

Com relação à utilização de livros eletrônicos como material didático, por favor, leia a definição abaixo e responda: 
Livro eletrônico: É um livro digital em arquivo texto ou sonoro que pode ser:

- Vendido (ou disponibilizado) na íntegra ou em partes

- Alugado (por acesso pago on-line por determinado período de tempo)

- Vendido por capítulos gerados de arquivo digital, mas impressos para o consumidor em um ponto de venda (Pasta do Professor).

Nesse sentido o importante não é como o livro será consumido (lido ou ouvido), mas sim como saiu da editora para ser comercializado.

\section{Professores}

9 - O(A) senhor(a) já utilizou livros eletrônicos para fins de trabalho ou lazer?

$\square \operatorname{Sim}$

$\square$ Não

10 - O(A) senhor(a) indica ou já indicou livros eletrônicos para seus alunos de graduação?

$\square \operatorname{Sim}$

$\square$ Não

11- O(A) senhor(a) conhece o modelo de negócio para venda de livros por capítulos impressos chamado "Pasta do Professor"?

$\square \mathrm{Sim}$

$\square$ Não

Profissionais

6- A empresa na qual trabalha comercializa livros eletrônicos?

Sim

Não

7- Em caso positivo, que modelo de comercialização utiliza?

$\square$ Próprio

Pasta do Professor

Outro. Favor especificar

8- Quais são os principais motivos para não existir oferta variada de títulos em modelos de negócio de livros eletrônicos? (marcar quantas alternativas quiser)

$\square$ Temor das editoras de que haja aumento de reproduções não autorizadas

$\square$ Problemas das editoras com a liberação de direitos autorais

Falta de interesse das editoras, não sei o motivo.

Falta de interesse do consumidor

Indefinição quanto ao formato digital em que deve ser oferecido

Outro(s) motivo(s). Qual(is)?

9- $\mathrm{O}(\mathrm{A})$ senhor(a) acha que o livro impresso vai deixar de ser o principal produto da indústria editorial de livros didáticos universitários até 2015? Por favor, comente.

Sim

Não

Talvez

As afirmações abaixo tinham como alternativas para respostas uma escala likert de 5 pontos de Discordo totalmente; Discordo; Nem concordo, nem discordo; Concordo e Concordo totalmente. A primeira afirmação foi aplicada aos professores e a segunda aos profissionais. 
Utilizou-se aqui nova numeração por conta das perguntas acima feita a professores e profissionais terem numeração distinta.

1. Utilizar livros eletrônicos faria com que os alunos tivessem acesso mais rápido à bibliografia do curso.

1. Os professores consideram que utilizar livros eletrônicos faria com que os alunos tivessem acesso mais rápido à bibliografia do curso.

2. Indicar livros eletrônicos se encaixaria bem no meu estilo de trabalho.

2. Indicar livros eletrônicos se encaixaria bem no estilo de trabalho dos professores.

3. Já tive diversas oportunidades de testar o uso de livros eletrônicos com meus alunos.

3. Os professores têm diversas oportunidades de testar o uso de livros eletrônicos com seus alunos.

4. Acredito que a utilização de livros eletrônicos seria incômoda para meus alunos.

4. Os professores acreditam que seria incômodo para seus alunos o uso de livros eletrônicos.

5. A indicação de livros eletrônicos para meus alunos seria vista com bons olhos pela comunidade acadêmica.

5. Os professores consideram que indicar a utilização de livros eletrônicos seria visto com bons olhos pela comunidade acadêmica.

6. Tenho visto o trabalho que outros professores desenvolvem com a indicação de livros eletrônicos.

6. Os professores têm como ver que tipo de trabalho seus colegas desenvolvem quando indicam livros eletrônicos.

7. Meus chefes esperam que eu indique livros eletrônicos.

7. Os chefes dos professores esperam que eles indiquem livros eletrônicos.

8. Eu não teria dificuldade alguma em comunicar a outros os resultados da indicação de livros eletrônicos.

8. Não seria difícil para um professor comunicar os resultados do uso de livros eletrônicos.

9. Eu sei onde posso encontrar livros eletrônicos para testá-los de maneira satisfatória.

9. Os professores sabem onde encontrar livros eletrônicos para poder testá-los de maneira satisfatória.

10. A utilização de livros eletrônicos levaria, frequentemente, a resultados frustrantes.

10. Os professores consideram que o uso de livros eletrônicos levaria, frequentemente, a resultados frustrantes.

11. Professores que indicassem livros eletrônicos teriam mais prestígio do que aqueles que não indicassem.

11. Professores que indicassem livros eletrônicos teriam mais prestígio do que aqueles que não indicassem. 
12. Indicar livros eletrônicos aumentaria a eficiência do meu trabalho.

12. Indicar livros eletrônicos aumentaria a eficiência do trabalho dos professores.

13. A indicação de livros eletrônicos é voluntária.

13. A indicação de livros eletrônicos é voluntária.

14. Acredito que poderia comunicar a outros as consequências da indicação de livros eletrônicos.

14. Os professores poderiam comunicar as consequências da indicação de livros eletrônicos.

15. Se eu indicasse livros eletrônicos teria maior controle sobre o meu trabalho.

15. Indicar livros eletrônicos daria maior controle aos professores sobre o seu trabalho.

16. Livros eletrônicos estão disponíveis para que eu possa testá-los adequadamente..

16. Os professores têm à disposição livros eletrônicos para poder testá-los adequadamente.

17. Aprender a utilizar livros eletrônicos seria fácil para meus alunos.

17. Os professores acreditam que seria fácil para seus alunos aprender a utilizar livros eletrônicos.

18. Na faculdade onde leciono, diversos professores indicam livros eletrônicos.

18. Diversos professores indicam livros eletrônicos.

19. Indicar livros eletrônicos aumentaria minha produtividade.

19. Indicar livros eletrônicos aumentaria a produtividade dos professores.

20. É fácil observar outros utilizando livros eletrônicos na faculdade.

20. É fácil para professores observar outros utilizando livros eletrônicos nas faculdades.

21. Apesar de ser possivelmente positivo, indicar livros eletrônicos não é obrigatório em meu trabalho.

21. Apesar de ser possivelmente positivo, indicar livros eletrônicos não é obrigatório para os professores.

22. Os resultados da utilização do livro eletrônico seriam claros para mim.

22. Os resultados da utilização de livros eletrônicos seriam claros para o professor.

23. Eu indicaria livros eletrônicos caso fossem mais baratos que os impressos.

23. Os professores indicariam livros eletrônicos caso fossem mais baratos do que os impressos.

24. Eu não tenho oportunidades adequadas para testar os diferentes usos de um livro eletrônico.

24. Os professores não têm oportunidades adequadas para testar os diferentes usos de um livro eletrônico.

25. Meus alunos teriam facilidade em utilizar livros eletrônicos por estarem acostumados com o formato digital. 
25. Os professores acreditam que seus alunos teriam facilidade de utilizar livros eletrônicos por estarem acostumados com o formato digital.

26. Existem poucos títulos de livros eletrônicos disponíveis, o que dificulta a sua indicação.

26. Por existirem poucos títulos de livros eletrônicos disponíveis, os professores têm dificuldade em indicá-los.

27. Eu indicaria livros eletrônicos caso fossem vendidos em partes.

27. Os professores indicariam livros eletrônicos caso fossem vendidos em partes.

28. O surgimento de dispositivos de leitura de livros eletrônicos que fazem a experiência de leitura em tela mais agradável faria com que eu indicasse, com mais frequência, livros eletrônicos.

28. O surgimento de dispositivos de leitura de livros eletrônicos que fazem a experiência de leitura em tela mais agradável, fará com que os professores indiquem, com mais frequência, livros eletrônicos.

29. Uma tentativa real de testar os vários usos do livro eletrônico no dia a dia não é possível.

29. Para os professores não é possível testar os vários usos do livro eletrônico de maneira real no seu dia a dia.

\section{Professores}

12- Qual(is) as característica(s) de livros eletrônicos listadas abaixo o(a) senhor(a) considera como vantagens relevantes para uma eventual utilização em sala de aula como material pedagógico?

Obs: Marcar quantas alternativas quiser

$\square$ As cópias são perfeitas

Acesso conveniente pela internet 24 horas por dia

Possibilidade de alterar o tamanho e tipo das fontes

Facilidade de busca

Podem ser vendidos em partes

Podem ser atualizados a qualquer momento

Podem ser conectados por meio de hipertexto (links)

Podem oferecer arquivos sonoros

Podem oferecer informação multimídia

Podem ser carregados em pequenos dispositivos

Nenhuma

Outra(s). Por favor, especifique

13- Havendo algum comentário que deseje fazer, por favor, escreva abaixo:

Profissionais

10- Havendo algum comentário que deseje fazer, por favor, escreva abaixo: 
APÊNDICE 3 - MÉDIAS, DESVIOS PADRÃO E INTERVALOS DE CONFIANÇA

DAS VARIÁVEIS

$1-$

\begin{tabular}{|l|c|c|c|c|}
\hline & Média & Desvio padrão & \multicolumn{2}{|c|}{$95 \%$ intervalo de confiança } \\
\hline Profissionais de editoras & 3,40 & 1,00 & 2,99 & 3,81 \\
\hline Professores USP & 4,13 & 0,62 & 3,90 & 4,36 \\
\hline Professores Mackenzie & 3,93 & 0,78 & 3,78 & 4,07 \\
\hline
\end{tabular}

$2-$

\begin{tabular}{|l|c|c|c|c|}
\hline & Média & Desvio padrão & \multicolumn{2}{|c|}{$95 \%$ intervalo de confiança } \\
\hline Profissionais de editoras & 2,92 & 0,76 & 2,61 & 3,23 \\
\hline Professores USP & 3,71 & 0,86 & 3,39 & 4,03 \\
\hline Professores Mackenzie & 3,75 & 0,88 & 3,58 & 3,92 \\
\hline
\end{tabular}

$3-$

\begin{tabular}{|l|c|c|c|c|}
\hline & Média & Desvio padrão & \multicolumn{2}{|c|}{$95 \%$ intervalo de confiança } \\
\hline Profissionais de editoras & 2,72 & 1,02 & 2,30 & 3,14 \\
\hline Professores USP & 1,65 & 1,02 & 1,27 & 2,02 \\
\hline Professores Mackenzie & 2,34 & 1,16 & 2,12 & 2,56 \\
\hline
\end{tabular}

4-

\begin{tabular}{|l|c|c|c|c|}
\hline & Média & Desvio padrão & \multicolumn{2}{|c|}{$95 \%$ intervalo de confiança } \\
\hline Profissionais de editoras & 3,20 & 0,96 & 2,80 & 3,60 \\
\hline Professores USP & 3,81 & 0,91 & 3,47 & 4,14 \\
\hline Professores Mackenzie & 3,77 & 0,83 & 3,61 & 3,93 \\
\hline
\end{tabular}

5-

\begin{tabular}{|l|c|c|c|c|}
\hline & Média & Desvio padrão & \multicolumn{2}{|c|}{$95 \%$ intervalo de confiança } \\
\hline Profissionais de editoras & 2,96 & 0,98 & 2,56 & 3,36 \\
\hline Professores USP & 3,19 & 0,98 & 2,83 & 3,55 \\
\hline Professores Mackenzie & 3,59 & 0,85 & 3,43 & 3,75 \\
\hline
\end{tabular}

6-

\begin{tabular}{|l|c|c|c|c|}
\hline & Média & Desvio padrão & \multicolumn{2}{|c|}{$95 \%$ intervalo de confiança } \\
\hline Profissionais de editoras & 2,72 & 0,89 & 2,35 & 3,09 \\
\hline Professores USP & 1,68 & 0,83 & 1,37 & 1,98 \\
\hline Professores Mackenzie & 1,99 & 0,93 & 1,81 & 2,17 \\
\hline
\end{tabular}

7-

\begin{tabular}{|l|c|c|c|c|}
\hline & Média & Desvio padrão & \multicolumn{2}{|c|}{$95 \%$ intervalo de confiança } \\
\hline Profissionais de editoras & 3,28 & 0,84 & 2,93 & 3,63 \\
\hline Professores USP & 3,71 & 0,94 & 3,37 & 4,05 \\
\hline Professores Mackenzie & 3,06 & 0,94 & 2,89 & 3,24 \\
\hline
\end{tabular}


8-

\begin{tabular}{|l|c|c|c|c|}
\hline & Média & Desvio padrão & \multicolumn{2}{|c|}{$95 \%$ intervalo de confiança } \\
\hline Profissionais de editoras & 2,88 & 1,01 & 2,46 & 3,30 \\
\hline Professores USP & 4,00 & 0,77 & 3,72 & 4,28 \\
\hline Professores Mackenzie & 4,06 & 0,83 & 3,91 & 4,22 \\
\hline
\end{tabular}

9-

\begin{tabular}{|l|c|c|c|c|}
\hline & Média & Desvio padrão & \multicolumn{2}{|c|}{$95 \%$ intervalo de confiança } \\
\hline Profissionais de editoras & 2,20 & 0,71 & 1,91 & 2,49 \\
\hline Professores USP & 2,03 & 1,05 & 1,65 & 2,42 \\
\hline Professores Mackenzie & 3,06 & 1,26 & 2,82 & 3,29 \\
\hline
\end{tabular}

10-

\begin{tabular}{|l|c|c|c|c|}
\hline & Média & Desvio padrão & \multicolumn{2}{c|}{$95 \%$ intervalo de confiança } \\
\hline Profissionais de editoras & 3,36 & 0,82 & 3,07 & 3,65 \\
\hline Professores USP & 3,71 & 0,72 & 3,41 & 4,01 \\
\hline Professores Mackenzie & 3,90 & 0,76 & 3,76 & 4,04 \\
\hline
\end{tabular}

11-

\begin{tabular}{|l|c|c|c|c|}
\hline & Média & Desvio padrão & \multicolumn{2}{|c|}{$95 \%$ intervalo de confiança } \\
\hline Profissionais de editoras & 2,36 & 1,11 & 1,90 & 2,82 \\
\hline Professores USP & 2,55 & 0,93 & 2,21 & 2,89 \\
\hline Professores Mackenzie & 2,51 & 0,93 & 2,34 & 2,69 \\
\hline
\end{tabular}

12-

\begin{tabular}{|l|c|c|c|c|}
\hline & Média & Desvio padrão & \multicolumn{2}{|c|}{$95 \%$ intervalo de confiança } \\
\hline Profissionais de editoras & 2,68 & 1,07 & 2,24 & 3,12 \\
\hline Professores USP & 3,10 & 1,01 & 2,73 & 3,47 \\
\hline Professores Mackenzie & 3,19 & 0,89 & 3,02 & 3,36 \\
\hline
\end{tabular}

$13-$

\begin{tabular}{|l|c|c|c|c|}
\hline & Média & Desvio padrão & \multicolumn{2}{|c|}{$95 \%$ intervalo de confiança } \\
\hline Profissionais de editoras & 3,60 & 0,91 & 3,22 & 3,98 \\
\hline Professores USP & 4,13 & 0,76 & 3,85 & 4,41 \\
\hline Professores Mackenzie & 4,04 & 0,71 & 3,90 & 4,17 \\
\hline
\end{tabular}

14-

\begin{tabular}{|l|c|c|c|c|}
\hline & Média & Desvio padrão & \multicolumn{2}{|c|}{$95 \%$ intervalo de confiança } \\
\hline Profissionais de editoras & 3,32 & 0,90 & 2,95 & 3,69 \\
\hline Professores USP & 3,84 & 0,82 & 3,54 & 4,14 \\
\hline Professores Mackenzie & 3,95 & 0,73 & 3,82 & 4,09 \\
\hline
\end{tabular}

15-

\begin{tabular}{|l|c|c|c|c|}
\hline & Média & Desvio padrão & \multicolumn{2}{c|}{$95 \%$ intervalo de confiança } \\
\hline Profissionais de editoras & 2,56 & 1,16 & 2,08 & 3,04 \\
\hline Professores USP & 2,87 & 0,76 & 2,59 & 3,15 \\
\hline Professores Mackenzie & 2,61 & 0,82 & 2,45 & 2,76 \\
\hline
\end{tabular}


$16-$

\begin{tabular}{|l|c|c|c|c|}
\hline & Média & Desvio padrão & \multicolumn{2}{c|}{$95 \%$ intervalo de confiança } \\
\hline Profissionais de editoras & 2,24 & 0,97 & 1,84 & 2,64 \\
\hline Professores USP & 2,29 & 0,82 & 1,99 & 2,59 \\
\hline Professores Mackenzie & 2,70 & 0,97 & 2,51 & 2,88 \\
\hline
\end{tabular}

$17-$

\begin{tabular}{|l|c|c|c|c|}
\hline & Média & Desvio padrão & \multicolumn{2}{c|}{$95 \%$ intervalo de confiança } \\
\hline Profissionais de editoras & 3,60 & 0,71 & 3,31 & 3,89 \\
\hline Professores USP & 4,03 & 0,71 & 3,77 & 4,29 \\
\hline Professores Mackenzie & 3,76 & 0,87 & 3,60 & 3,93 \\
\hline
\end{tabular}

$18-$

\begin{tabular}{|l|c|c|c|c|}
\hline & Média & Desvio padrão & \multicolumn{2}{|c|}{$95 \%$ intervalo de confiança } \\
\hline Profissionais de editoras & 2,44 & 0,71 & 2,15 & 2,73 \\
\hline Professores USP & 2,03 & 0,87 & 1,71 & 2,35 \\
\hline Professores Mackenzie & 2,72 & 0,65 & 2,60 & 2,85 \\
\hline
\end{tabular}

$19-$

\begin{tabular}{|l|c|c|c|c|}
\hline & Média & Desvio padrão & \multicolumn{2}{|c|}{$95 \%$ intervalo de confiança } \\
\hline Profissionais de editoras & 2,84 & 1,03 & 2,42 & 3,26 \\
\hline Professores USP & 2,84 & 1,04 & 2,46 & 3,22 \\
\hline Professores Mackenzie & 2,80 & 0,90 & 2,63 & 2,97 \\
\hline
\end{tabular}

20-

\begin{tabular}{|l|c|c|c|c|}
\hline & Média & Desvio padrão & \multicolumn{2}{|c|}{$95 \%$ intervalo de confiança } \\
\hline Profissionais de editoras & 2,40 & 0,58 & 2,16 & 2,64 \\
\hline Professores USP & 1,77 & 0,80 & 1,48 & 2,07 \\
\hline Professores Mackenzie & 2,12 & 0,88 & 1,95 & 2,29 \\
\hline
\end{tabular}

21

\begin{tabular}{|l|c|c|c|c|}
\hline & Média & Desvio padrão & \multicolumn{2}{|c|}{$95 \%$ intervalo de confiança } \\
\hline Profissionais de editoras & 3,84 & 0,69 & 3,56 & 4,12 \\
\hline Professores USP & 4,29 & 0,78 & 4,00 & 4,58 \\
\hline Professores Mackenzie & 3,96 & 0,79 & 3,81 & 4,11 \\
\hline
\end{tabular}

22

\begin{tabular}{|l|c|c|c|c|}
\hline & Média & Desvio padrão & \multicolumn{2}{|c|}{$95 \%$ intervalo de confiança } \\
\hline Profissionais de editoras & 2,80 & 1,08 & 2,35 & 3,25 \\
\hline Professores USP & 3,06 & 0,81 & 2,77 & 3,36 \\
\hline Professores Mackenzie & 3,16 & 0,85 & 2,99 & 3,32 \\
\hline
\end{tabular}


23-

\begin{tabular}{|l|c|c|c|c|}
\hline & Média & Desvio padrão & \multicolumn{2}{|c|}{$95 \%$ intervalo de confiança } \\
\hline Profissionais de editoras & 3,64 & 0,86 & 3,28 & 4,00 \\
\hline Professores USP & 3,84 & 0,82 & 3,54 & 4,14 \\
\hline Professores Mackenzie & 3,90 & 0,99 & 3,71 & 4,09 \\
\hline
\end{tabular}

24-

\begin{tabular}{|l|c|c|c|c|}
\hline & Média & Desvio padrão & \multicolumn{2}{|c|}{$95 \%$ intervalo de confiança } \\
\hline Profissionais de editoras & 2,44 & 0,92 & 2,06 & 2,82 \\
\hline Professores USP & 2,81 & 1,25 & 2,35 & 3,26 \\
\hline Professores Mackenzie & 2,79 & 1,06 & 2,59 & 2,99 \\
\hline
\end{tabular}

25-

\begin{tabular}{|l|c|c|c|c|}
\hline & Média & Desvio padrão & \multicolumn{2}{|c|}{$95 \%$ intervalo de confiança } \\
\hline Profissionais de editoras & 3,64 & 0,91 & 3,27 & 4,01 \\
\hline Professores USP & 3,77 & 0,99 & 3,41 & 4,14 \\
\hline Professores Mackenzie & 3,60 & 0,99 & 3,41 & 3,78 \\
\hline
\end{tabular}

26-

\begin{tabular}{|l|c|c|c|c|}
\hline & Média & Desvio padrão & \multicolumn{2}{|c|}{$95 \%$ intervalo de confiança } \\
\hline Profissionais de editoras & 2,20 & 0,82 & 1,86 & 2,54 \\
\hline Professores USP & 2,39 & 0,92 & 2,05 & 2,72 \\
\hline Professores Mackenzie & 2,35 & 0,84 & 2,19 & 2,51 \\
\hline
\end{tabular}

27

\begin{tabular}{|l|c|c|c|c|}
\hline & Média & Desvio padrão & \multicolumn{2}{|c|}{$95 \%$ intervalo de confiança } \\
\hline Profissionais de editoras & 3,72 & 0,84 & 3,37 & 4,07 \\
\hline Professores USP & 3,77 & 0,99 & 3,41 & 4,14 \\
\hline Professores Mackenzie & 3,70 & 0,94 & 3,52 & 3,88 \\
\hline
\end{tabular}

28-

\begin{tabular}{|l|c|c|c|c|}
\hline & Média & Desvio padrão & \multicolumn{2}{|c|}{$95 \%$ intervalo de confiança } \\
\hline Profissionais de editoras & 3,68 & 0,85 & 3,33 & 4,03 \\
\hline Professores USP & 3,55 & 0,89 & 3,22 & 3,87 \\
\hline Professores Mackenzie & 3,47 & 1,02 & 3,27 & 3,66 \\
\hline
\end{tabular}

29-

\begin{tabular}{|l|c|c|c|c|}
\hline & Média & Desvio padrão & \multicolumn{2}{|c|}{$95 \%$ intervalo de confiança } \\
\hline Profissionais de editoras & 2,56 & 0,82 & 2,22 & 2,90 \\
\hline Professores USP & 3,26 & 0,96 & 2,90 & 3,61 \\
\hline Professores Mackenzie & 3,51 & 0,89 & 3,35 & 3,68 \\
\hline
\end{tabular}




\section{APÊNDICE 4 - ALTERNATIVAS À COMERCIALIZAÇÃO DO LIVRO IMPRESSO, UTILIZANDO-SE TECNOLOGIAS LIGADAS À DIGITALIZAÇÃO E/OU À INTERNET}

Com a digitalização dos conteúdos e a disseminação da internet no final dos anos 1990, diversos especialistas do mercado apontaram para o fim do livro impresso. O formato digital substituiria o papel, e a internet substituiria as livrarias como canal de distribuição. Grupos editoriais começaram a investir em alternativas à venda de seu conteúdo. Empresas de tecnologia acreditaram que esse era um mercado promissor e investiram em diversas direções. Empreendedores buscaram financiamentos, abundantes naquela época, para empreendimentos ligados a novas tecnologias e caminhos para comercialização do antigo livro de papel. Mas, apesar da importância das livrarias virtuais, estas vendem prioritariamente livros em papel. O livro impresso não sucumbiu e boa parte dos investimentos foi perdida (GOMEZ, 2008; THOMPSON, 2005).

Por outro lado, empresas que iniciaram alguns anos depois, de maneira menos intensa a busca de alternativas, vem apresentando soluções que podem vir a substituir o livro impresso como principal produto comercializado pelas editoras de livros.

Seguem listadas abaixo algumas das principais alternativas atualmente oferecidas.

a) Livros customizados: Muitos professores sentem que os livros didáticos são padronizados e estudantes reclamam que ao final do curso acabam não utilizando todo o seu conteúdo. Por conta dessas necessidades e da disponibilidade tecnológica, algumas editoras passaram a oferecer o livro customizado. O livro é feito sob medida para um professor ou um curso (THOMPSON, 2005). Martyns (2006) levanta a hipótese de que com o aumento da especialização no ensino superior, os estudantes relutam em comprar livros textos dos quais usarão apenas parte do conteúdo. O modelo de negócios de livros customizados possibilita aos professores poder escolher, dentro do conteúdo de uma determinada empresa, capítulos ou páginas de livros e montar o seu livro didático. Notas e trabalhos em classe elaborados pelo docente podem ser acrescentados ao produto (Ex. <http://www.pearsoncustom.com> Acesso em 19 abr. 2008). 
b) Comercialização do conteúdo fracionado impresso: Algumas das principais editoras de livros didáticos de ensino superior atuantes no Brasil (Ex. Saraiva, Guanabara-Koogan, Atlas, Pearson, Artmed) se uniram para oferecer uma alternativa à cópia não autorizada de livros e também ao consumo integral de livros e lançou a Pasta do Professor. Nesse modelo de negócios, os consumidores podem comprar partes de livros impressos, mas somente em pontos autorizados (<http://www.pastadoprofessor.com.br> Acesso em 19 abr. 2008). Esse modelo de negócios só existe no Brasil. $^{22}$

c) Comercialização de conteúdo fracionado digital: Venda de capítulos de livros em diversos formatos para ser lido na tela em computadores ou qualquer outra mídia compatível. Uma das editoras que passou a trabalhar com este modelo de negócio é a Random House, uma das maiores do mundo. (<http://www.randomhouse.com/madetostick/> Acesso em 28 jun. 2008).

d) Comercialização de conteúdo digital na íntegra (livro eletrônico): Venda do livro em algum formato digital para ser lido em computadores ou qualquer outra mídia eletrônica. Diversas editoras atuam dessa maneira, um exemplo de editora de livros de interesse geral brasileira é a Giz Editorial (<http://www.gizeditorial.com.br>; acesso em 15 fev. 2008). Um exemplo de venda de livros didáticos digitais na íntegra pode ser encontrado em <http://textbooks.zinio.com/>; acesso em 28 jun. 2008.

e) Aluguel do conteúdo digital: Segundo Rifkin (2001), na nova sociedade de acesso, os fornecedores têm a propriedade, mas não a vendem, cobram uma assinatura, alugam ou fazem leasing. É a economia de fornecedores e usuários, no lugar da de vendedores e compradores. Por meio de contratos com instituições de ensino, algumas editoras disponibilizam seu conteúdo para estudantes e professores por meio de senhas. Esse sistema é semelhante ao modelo existente para boa parte das revistas cientificas, mas não envolve cópias físicas. O aluguel também é feito livro a livro para quem tiver interesse em pagar para acesso por tempo limitado. Um exemplo é a Pearson do Brasil (<http://www.bvirtual.com.br/cont/login/Index_Piloto.jsp?ID=pear>; acesso em 21 abr. 2008). Outro é uma empresa que reúne livros didáticos de diversas editoras $<$ http://www.coursesmart.com/>; acesso em 02 jun. 2008.

f) Exibição gratuita de trechos de livros: O Google iniciou no ano de 2005 seu programa chamado Google Books. Ele consiste em digitalizar e disponibilizar livros na internet. No caso dos livros com direitos autorais vigentes, normalmente o autorizante libera

\footnotetext{
${ }^{22}$ Ver Apêndice 5.
} 
apenas um percentual de exibição do livro. Para o Google, é mais conteúdo para exibir e para o detentor dos direitos, uma possível propaganda, uma amostra de seu livro. Disponível em <http://books.google.com.br/>; acesso em 28 jun. 2008

g) Venda de livros sonoros: Uma das editoras brasileiras que iniciou um modelo de negócios de livros falados é a Ediouro. Nele artistas conhecidos leem obras famosas e os arquivos são vendidos pela internet ou em CDs para serem ouvidos. Disponível em $<$ http://www.plugme.com.br/>; acesso em 29 jun. 2008.

h) Sumários de livros clássicos falados ou em formato texto para serem lidos no Iphone. <http://www.zapptek.com/> ; acesso em 10 jan. 2009

i) Permitir a baixa gratuita do conteúdo pela internet, vender produtos agregados. Essa é a proposta da Flat World Knowledge. Enquanto os estudantes podem baixar gratuitamente o conteúdo de seus livros, a empresa ganha dinheiro vendendo formato impresso, guias do estudante, versões para o Kindle. <http://www.flatworldknowledge.com/minisite/>; acesso em 08 jan. 2009 


\section{APÊNDICE 5 - A PASTA DO PROFESSOR}

A Pasta do Professor é uma iniciativa de algumas das principais editoras de livros universitários. Ela nasceu da constatação dessas editoras de que o mercado consumidor tem interesse em consumir livros também por pedaços. Segundo seu sítio:

Esta é uma iniciativa pioneira das editoras de livros no Brasil e tem por objetivo disponibilizar o conteúdo de suas obras publicadas para ser alternativamente adquirido também de forma fracionada.

Nos últimos anos a expansão do ensino universitário brasileiro tem gerado novas demandas. Entre elas destacam-se o interesse e até a necessidade dos estudantes em adquirir apenas partes dos livros impressos disponíveis nas livrarias, bem como também poder adquirir estas diversas parcelas de conteúdo apontadas nas bibliografias dos seus cursos ao longo do período letivo.

Infelizmente, problemas de escala industrial ou logística impediam as editoras e seus autores de atender a esta demanda. Esta lacuna foi a oportunidade para muitas distorções e procedimentos, mas que geram muitos problemas, com destaque à própria ameaça à continuidade de geração e disponibilização de conteúdo de qualidade no médio e longo prazo.

O portal pastadoprofessor.com.br foi criado exatamente para atender à demanda dos alunos em adquirir conteúdo de suas bibliografias de forma fracionada. Sua criação levou em conta a aplicação de um modelo de negócios viável, em que o respeito ao direito autoral e editorial esteja presente e que, consequentemente, assegure a atratividade para os autores e editoras de investir na continuidade da expansão do acervo de conteúdo em português para a crescente população de alunos brasileiros. (PASTA DO PROFESSOR, 2008).

Participam da iniciativa as editoras Artmed, Atlas, Guanabara/Koogan, Record, Saraiva, Jorge Zahar, Pearson Education, Ediouro, Forense, Manole, Revista dos Tribunais, Elsevier e LTC. 


\section{APÊNDICE 6 - LISTA DAS EDITORAS ANALISADAS}

Informadas pela ABDR e aprovadas pelo pesquisador

- Artmed - http://www.artmed.com.br

- Ática - http://www.atica.com.br

- Atlas - http://www.editoraatlas.com.br/Atlas/portal/homePortal.ctrl.aspx

- Cengage Learning - http://www.thomsonlearning.com.br/home.do

- Manole - http://www.manole.com.br

- Elsevier - http://www.campus.com.br

- Ibpex - http://www.editoraibpex.com.br/

- Juruá - http://www.jurua.com.br/

- LTC - http://editoraltc.shop.com.br/

- M Books - http://www.mbooks.com.br/

- Pearson - http://www.pearson.com.br/

- Qualitymark - http://www.qualitymark.com.br/

- Saint Paul Editora - http://www.saintpaul.com.br/

- Saraiva - http://www.editorasaraiva.com.br/

- Summus - http://www.gruposummus.com.br/summus/index.php

Informadas pela ABDR e não aprovadas pelo pesquisador

- Cortez - http://www.cortezeditora.com.br

- Aduaneiras - http://www.aduaneiras.com.br/

- Edipurcrs - http://www.pucrs.br/edipucrs/

- Erica - http://www.editoraerica.com.br

- Cia. Das Letras - http://www.companhiadasletras.com.br/

- Harbra - http://www.harbra.com.br/loja/

- Senac - http://www.editorasenacsp.com.br/ e http://senac.br/livrariavirtual

- Educ - http://www.pucsp.br/educ/

- Jorge Zahar - http://www.zahar.com.br

- Papirus - http://www.papirus.com.br/

Lista das editoras não indicadas pela ABDR, mas que se encaixam no perfil desejado: 
- Mcgraw hill - http://www.mcgraw-hill.com.br/

- Alinea - http://www.atomoealinea.com.br/

- Editora da FGV - http://www.editora.fgv.br/ 


\section{APÊNDICE 7 - MÉDIAS, DESVIOS PADRÃO E INTERVALOS DE CONFIANÇA \\ DOS FATORES}

USP

\begin{tabular}{|l|l|l|l|l|}
\hline & média & desvio padrão & \multicolumn{2}{|l|}{$95 \%$ intervalo de confiança } \\
\hline Vantagem relativa & 3,42 & 0,65 & 3,19 & 3,66 \\
\hline Compatibilidade & 3,71 & 0,86 & 3,39 & 4,02 \\
\hline Experimentação & 2,40 & 0,57 & 2,19 & 2,61 \\
\hline Facilidade de uso & 3,77 & 0,53 & 3,58 & 3,97 \\
\hline Imagem & 2,87 & 0,80 & 2,58 & 3,16 \\
\hline Visibilidade & 1,83 & 0,68 & 1,58 & 2,08 \\
\hline Uso voluntário & 4,04 & 0,68 & 3,79 & 4,29 \\
\hline $\begin{array}{l}\text { Demonstração de } \\
\text { resultados }\end{array}$ & 3,63 & 0,49 & 3,45 & 3,81 \\
\hline
\end{tabular}

Mackenzie

\begin{tabular}{|l|l|l|l|l|}
\hline & média & desvio padrão & \multicolumn{2}{|l|}{$95 \%$ intervalo de confiança } \\
\hline Vantagem relativa & 3,35 & 0,57 & 3,25 & 3,46 \\
\hline Compatibilidade & 3,75 & 0,88 & 3,59 & 3,92 \\
\hline Experimentação & 2,79 & 0,59 & 2,68 & 2,90 \\
\hline Facilidade de uso & 3,70 & 0,55 & 3,60 & 3,80 \\
\hline Imagem & 3,05 & 0,69 & 2,92 & 3,18 \\
\hline Visibilidade & 2,28 & 0,62 & 2,16 & 2,40 \\
\hline Uso voluntário & 3,69 & 0,55 & 3,59 & 3,79 \\
\hline $\begin{array}{l}\text { Demonstração de } \\
\text { resultados }\end{array}$ & 3,72 & 0,58 & 3,62 & 3,83 \\
\hline
\end{tabular}




\section{APÊNDICE 8 - MINICURRÍCULO DOS ESPECIALISTAS}

Especialista 1: Pollyana Ferrari é jornalista formada pela PUC-SP, mestre e doutora em Ciências da Comunicação pela ECA/USP. Professora na PUC-SP, onde ministra aulas nos cursos de Jornalismo (Edição Jornalística e Jornalismo On-line) e Multimeios (Hipertexto), na graduação da PUC/SP. Na pós-graduação da PUC/SP, ministra os cursos de Design, Programação Visual e Infografia e Jornalismo On-line. Na UNIFIEO, responde pelas disciplinas Mídia Interativa e Jornalismo On-line.

Especialista 2: Felipe Pena é professor de pós-graduação em Comunicação. É doutor em Literatura pela PUC-Rio e foi sub-reitor da Universidade Estácio de Sá, onde também ocupou o cargo de diretor da Faculdade de Comunicação Social. Autor de diversos livros, todos na área de comunicação.

Especialista 3: Welington Andrade, doutor em literatura brasileira pela USP, trabalha nas áreas de educação, cultura e edição e é professor de Técnica de Redação da Faculdade Cásper Líbero (onde atualmente também exerce o cargo de vice-diretor). 


\section{APÊNDICE 9 - ENTREVISTAS}

Rodrigo Velloso é diretor de desenvolvimento de negócios do Google.

Você acredita que o livro impresso deixará de ser o principal produto das editoras até 2015 ? Não. No caso dos livros didáticos universitários, a possibilidade é maior, pois em formato eletrônico têm algumas vantagens interessantes em relação ao impresso como possibilidade de atualização, multimídia e facilidade de busca, por exemplo.

O Google tem planos de comercializar livros eletrônicos?

Sim. Estudam-se dois modelos atualmente:

1- Venda do conteúdo para acesso on-line. O principal problema nesse modelo é quando o detentor de direitos autorais deixar de disponibilizar a obra, mas como a vendemos, temos que garantir o acesso. A solução talvez seja enviar um arquivo para o comprador ao final do contrato da editora.

2- Outro modelo é aluguel institucional por IP, paga-se por máquina para acesso em toda a base. Não se pensa em separar em bases distintas (por área de conhecimento ou tipo de livro), até porque o custo de acréscimo de um item à base é muito pequeno. Para as editoras, se pagaria por acesso.

O que muda caso o acordo do Google proposto às editoras ${ }^{23}$ seja aprovado?

O Google poderá vender livros que não tem detentores de direitos autorais. Dos 7,5 milhões de livros que temos digitalizados, cerca de 6 milhões estão nessa categoria. Vamos dar nova vida a diversas obras antes inacessíveis.

Já existe um Ipod dos livros? Você acredita que existirá?

Não existe hoje. Mas sim, acredito que existirá. O maior problema é que não existe um formato padrão. No caso da música, é MP3. No caso de livros, por conta do consumo atualmente ser principalmente em papel, ainda não se chegou a um formato padrão e que agrade a maioria dos consumidores.

\footnotetext{
${ }^{23}$ A respeito, ver: http://books.google.com/intl/pt-BR/googlebooks/agreement/
} 
Como contornar o receio que os editores e detentores de direitos autorais têm da reprodução não autorizada em um universo digital?

Eles deveriam era ter medo de não terem seus livros reproduzidos, o que significaria que não interessam a ninguém. É essencial que o conteúdo seja importante para as pessoas.

$\mathrm{O}$ fato é que os editores continuam pensando em transplantar para o digital seus modelos de venda e distribuição do mundo físico. Nesse caso, concordo que uma classe de alunos poderia comprar apenas um exemplar eletrônico para todos acessarem. Mas por que pensar o livro como algo estático, uno, sem atualizações ou patrocínios? Por que não pensar em ganhar dinheiro com palestras dos autores, com acesso digital diretamente para as instituições...

No fundo, jornais, revistas e livros são indústrias bem distintas por conta do modelo de distribuição e pelo produto físico. Mas são todos provedores de conteúdo que deveriam pensar na mesma direção no novo mundo digital. Como disse o articulista Kevin Kelly, a internet é uma grande máquina copiadora. E as cópias são gratuitas...

A indústria da tecnologia será mais importante do que a de conteúdo no caso de livros como é no da música?

Discordo da afirmação. Para mim o conteúdo ainda é rei. O problema é que há um apego excessivo ao modelo de negócio atual e se quer transplantá-lo para o novo. As pessoas estão dispostas a pagar por conteúdo. No entanto deve-se perceber que duas das barreiras de entrada no negócio de livros e música, que eram o custo e a complexidade de produção, praticamente não existem mais. É barato e simples produzir um livro ou uma música. O que existe é excesso de conteúdo e é difícil se destacar, ser encontrado. Talvez seja esse o papel principal dos agregadores daqui para frente.

Na pesquisa que realizei, profissionais de editoras apresentaram sua visão sobre a percepção de professores no que se refere à adoção de livros eletrônicos. Uma das conclusões é de que os professores, mesmo utilizando pouco, parecem muito mais preparados para passar a adotálos do que os profissionais parecem crer. Isso surpreende?

Não. Os professores não são casados com o modelo de negócio tradicional das editoras. Eles não têm como preocupação principal coibir pirataria ou encontrar um modelo de negócio que remunere a editora ou autores (muitas vezes, eles mesmos). Preocupam-se em oferecer a seus alunos algo mais conveniente tanto em termos de conteúdo (atualizado), quanto em forma (aos pedaços, ter possibilidade de busca) e custo. E nisso, o eletrônico pode ser melhor. 
Fábio Herz é diretor comercial da Livraria Cultura

O Google tem planos de comercializar livros eletrônicos. Isso pode incomodar? O Kindle já incomoda o mercado de livros impressos nos EUA?

Não, o Kindle ainda representa muito pouco nos EUA. Estive lá há pouco tempo e vi no aeroporto de Dallas uma turma de universitárias. Quase todas tinham um laptop na mão, mas liam livros impressos. O comportamento do consumidor ainda está muito ligado ao papel. Ao contrário da música, que pode ser ouvida só, em grupo ou fazendo outras atividades, o consumo do livro é, na maior parte das vezes, solitário. Além disso, ouvir Mp3 ou um vinil é muito parecido, mas ler em papel ou em qualquer outro mecanismo eletrônico é muito diferente. Acho que a tendência é que sim, que o livro eletrônico será uma realidade, mas ainda falta muito. Se nos EUA ainda está longe de ser um mercado importante, no Brasil vai demorar muito mais. Acho que existem situações em que um aparelho como o Kindle pode ser muito útil, como em uma viagem, na qual ao invés de se carregar dez livros, se leva apenas o aparelho, o que chamo de consumo ocasional. Mas para mim, o consumidor é multicanal. $O$ fato de ele usar cada vez mais a internet não significa necessariamente que não se interessa mais por livros.

Existe o Ipod dos livros?

Não. E a penetração de um produto como o Kindle é absurdamente mais lenta do que a do Ipod. O Ipod surgiu por uma dificuldade que a indústria fonográfica teve em atender a uma demanda. Essa demanda ainda não existe no caso de livros digitais, ela está sendo criada. É verdade que em alguns casos, como livros universitários, muitas vezes as vantagens como busca ou atualização podem fazer com que fiquem mais interessantes os eletrônicos do que os de papel, mas não é assim em todas as áreas.

A indústria da tecnologia será mais forte do que a de conteúdo no caso dos livros como é no da música?

A tendência do conteúdo é ficar cada vez mais barato. E se não for mais barato, acabará saindo "de graça". Parece que as editoras estão mais preocupadas do que estavam as gravadoras e por isso experimentando novas formulas. É possível que isso ocorra, mas o mercado de livros está em um momento bem diferente do fonográfico. 
Na pesquisa que realizei, profissionais de editoras apresentaram sua visão sobre a percepção de professores no que se refere à adoção de livros eletrônicos. Uma das conclusões é de que os professores, mesmo utilizando pouco, parecem muito mais preparados para utilizá-los do que os profissionais parecem crer. Isso surpreende?

Não muito. No entanto, ainda faltam muitas etapas para o livro eletrônico ter penetração no mercado universitário. Além das pessoas terem acesso a computadores, elas precisam ter o hábito de usá-lo como ferramenta de estudo, o que não acredito ocorrer hoje. Acho impensável pelo menos para os próximos cinco anos que haja grandes mudanças ligadas ao consumo do conteúdo.

A Cultura já tentou há alguns anos a venda de livros eletrônicos e não deu certo. Existem planos para voltar a vender livros eletrônicos?

Não, mas estamos ligados no mercado para participarmos da cadeia de venda dos livros, mesmo sendo eles eletrônicos.

Você acredita que o livro impresso deixará de ser o produto principal das editoras até 2015? Não. Acredito que o mercado de livros eletrônicos não representará mais do que 5\% do total até lá.

Frederico Indiani é diretor comercial da Livraria Saraiva

Existe o Ipod dos livros?

Não, não existe. Mas é bem possível que venha a existir.

A indústria da tecnologia será mais forte do que a de conteúdo no caso dos livros como é no da música?

As editoras estão muito mais bem preparadas do que as gravadoras para uma possível mudança de paradigma. Elas já experimentam alguns modelos como da Pasta do Professor. Aliás, essa é uma iniciativa muito interessante que teria tudo para dar certo, mas pelo jeito não vem bem.

Na pesquisa que realizei profissionais de editoras apresentaram sua visão sobre a percepção de professores no que se refere à adoção de livros eletrônicos. Uma das conclusões é de que 
os professores, mesmo utilizando pouco, parecem muito mais preparados para utilizá-los do que os profissionais parecem crer. Isso surpreende?

Não surpreende. Mas apesar dessa diferença de percepção, acredito, como disse anteriormente, que elas estarão mais preparadas se e quando for necessário. Por outro lado, entendo que esse segmento, assim como o de livros de referência, está mais sujeito, ou pelo menos mais próximo, de ser afetados por livros eletrônicos.

A Saraiva tem planos para vender livros eletrônicos?

Não.

Você acredita que o livro impresso deixará de ser o produto principal das editoras até 2015 ? Não. Nem mais para frente. Acho que o impresso continuará existindo por muito tempo, assim como acredito que os CDs também não deixarão de existir. Como presentear alguém com 12 músicas pela internet? Ou dar de presente um download do best-seller atual? Já um livro e um CD são tangíveis. 
ANEXOS

ANEXO 1 - LEI DO LIVRO

ANEXO 2 - BIBLIOGRAFIA 


\section{ANEXO 1 - LEI DO LIVRO}

\section{CAPÍTULO I \\ DA POLÍTICA NACIONAL DO LIVRO \\ DIRETRIZES GERAIS}

Art. $1^{\circ}$ Esta Lei institui a Política Nacional do Livro, mediante as seguintes diretrizes

II - o livro é o meio principal e insubstituível da difusão da cultura e transmissão do conhecimento, do fomento à pesquisa social e científica, da conservação do patrimônio nacional, da transformação e aperfeiçoamento social e da melhoria da qualidade de vida;

\section{CAPÍTULO II \\ DO LIVRO}

Art. $2^{\circ}$ Considera-se livro, para efeitos desta Lei, a publicação de textos escritos em fichas ou folhas, não periódica, grampeada, colada ou costurada, em volume cartonado, encadernado ou em brochura, em capas avulsas, em qualquer formato e acabamento.

Parágrafo único. São equiparados a livro:

I - fascículos, publicações de qualquer natureza que representem parte de livro; II - materiais avulsos relacionados com livro, impressos em papel ou em material similar; III - roteiros de leitura para controle e estudo de literatura ou de obras didáticas; IV - álbuns para colorir, pintar, recortar ou armar; V - Atlas geográficos, históricos, anatômicos, mapas e cartogramas; VI - textos derivados de livro ou originais, produzidos por editores, mediante contrato de edição celebrado com o autor, com a utilização de qualquer suporte; VII - livros em meio digital, magnético e ótico, para uso exclusivo de pessoas com deficiência visual;

VIII - livros impressos no Sistema Braille. 


\section{ANEXO 2 - BIBLIOGRAFIA}

AMERICAN BOOKSELLERS ASSOCIATION. Disponível em <http://www.bookweb.org/index.html>. Acesso em: 10/05/2007.

ANDERSON, Chris. The Long Tail: Why the future of business is selling less of more. New York: Hyperion, 2006.

ARAÚJO, Thiago; GALDO, Alessandro; ARDIGO, Juilibio David. Conteúdos digitais de livros na sociedade do conhecimento. Data grama zero - Revista de ciência e informação, v. 9 , n. 5, out. 2008 .

BOOK INDUSTRY GROUP. Disponível em <http://www.bisg.org/index.html>. Acesso em: 03/09/2007.

BROWN, Laura; GRIFFITHS, Rebeca; RASCOFF, Matthew. University Publishing in a digital age. Ithaka Report, 2007.

CAFESCRIBE. Disponível em <http://www.cafescribe.com/>. Acesso em: 08/08/2007.

CAVALLI, Nicola. The symbolic dimension of innovation processes. American behavioral scientist, v. 50, 2007.

CHUDONOV, D. Docster: the future of document delivery?. Library Journal, v. 125, n. 13, Aug. 2000.

COLLINS, J. The future of academic publishing. What is open acess? Journal of the American College of Radiology, v. 2, ed. 4, p. 321-326, Apr. 2005.

; HUSSEY, Roger. Pesquisa em administração. Porto Alegre: Bookman, 2003.

COMPUTER HISTORY MUSEUM. Disponível em <http://www.computerhistory.org> Acesso em: 21/03/2008.

COOPER, Donald R.; SCHINDLER, Pámela S. Método de pesquisa em administração. Porto Alegre: Bookman, 2003.

CHRISTENSEN, Clayton M. The innovators dilemma. New York: Harper Business, 2000.

CREATIVE COMMONS. Disponível em <http://creativecommons.org:80/>. Acesso em: 22/02/2008.

EARP, Fábio Sá; KORNIS, George. A economia da cadeia produtiva do livro. Rio de Janeiro: BNDES, 2005.

ECO, Humberto Como se faz uma tese. São Paulo: Perspectiva, 2006.

EDUCHOICES. Disponível em <http://educhoices.org/articles/Online_Libraries__25_Places_to_Read_Free_Books_Online.html>. Acesso em: 05/01/2009. 
E-LIVRO. Disponível em <http://www.e-livro.com/>. Acesso em: 03/09/2007.

GIZ EDITORIAL. Disponível em <http://www.gizeditorial.com.br>. Acesso em: $15 / 02 / 2008$.

GLAZER, Rashi. Marketing in a information-intenvise enviroment: strategic implications of knwoledge as na asset. Journal of Marketing, n. 55, oct. 1991.

GOOGLE BOOKS. Disponível em <http://books.google.com.br/>. Acesso em: 28/06/2008.

HALLEWELL, Laurence. O livro no Brasil. 2. ed. São Paulo: Edusp, 2005.

HERTHER, Nancy K. The Ebook reader is not the future of Ebooks. Searcher, v. 16, ed. 8, p. 26-40, sep. 2008.

INFORMATION TECHNOLOGY INDUSTRY COUNCIL. Disponível em $<$ http://www.itic.org/>. Acesso em: 25/01/2008.

INSTITUTO BRASILEIRO DE INFORMAÇÃO EM CIÊNCIA E TECNOLOGIA. Disponível em <http://www.ibict.br>. Acesso em: 05/07/2007.

INTERNATIONAL PUBLISHER ASSOCIATION. Disponível em <http://www.ipauie.org>. Acesso em: 25 /02/2008.

INTERNET WORLD STATS. Disponível em <http://www.internetworldstats.com>. Acesso em: 02/04/2008.

ITHAKA. Disponível em <http://www.ithaka.org/> . Acesso em: 02/07/2008.

ITUNES. Disponível em <http://www.itunes.com>. Acesso em: 05/10/2007.

KORTH, Leomar Cláudio. As transformações na indústria editorial de livros no Brasil e os desafios para as empresas brasileiras. Mestrado executivo em gestão empresarial apresentado à Fundação Getúlio Vargas, 2005.

LIMA, Anelena Pereira; GUIMARÃES, Maria Eduarda Araújo; VENTURA, Mauro. Momentos do livro no Brasil. São Paulo: Ática, 1997.

LINDOSO, Felipe. O Brasil pode ser um país de leitores? São Paulo: Summus, 2004.

MCGRAW HILL. Disponível em <http://textbooks.zinio.com> Acesso em: 28/06/2008.

MOSTAFA, Solange; PACHECO, Márcia O mercado emergente da informação. Ciência da informação, Brasília, v. 24, n. 2, maio/ago. 1995.

NATIONAL E-BOOKS OBSERVATORY PROJECT. Disponível em $<$ http://www.jiscebooksproject.org/>. Acesso em: 02/10/2007. 
NATIONAL ENDOWMENT FOR THE ARTS. To read or not to read, Washington, 2007. Disponível em <http://www.nea.gov/research/toread.pdf>. Acesso em: 10/01/2009.

NETO, José Castilho Marques. O que fazer com os conteúdos? O livro do século XXI na avaliação acadêmica. Palestra proferida no Simposio "O futuro do livro na avaliação de programas de pós graduação durante a 57 reunião anual da SBPC, 2005.

NUNO, Edson; CARVALHO, Márcia Marques de. Ensino universitário, corporação e profissão: paradoxos e dilemas brasileiros Rio de Janeiro: Observatório Universitário Documento n. 63. Observatório Universitário, 2006.

OVERDRIVE. Disponível em <http://www.overdrive.com/>. Acesso em: 13/02/2008.

PEARSON. Disponível em <http://www.pearsoncustom.com> . Acesso em: 19/04/2008.

PEARSON DO BRASIL. $\quad$ Disponível em <http://www.bvirtual.com.br/cont/login/Index_Piloto.jsp?ID=pear>. Acesso em: 21/04/2008.

PICARD, Robert G. Cash Cows or Entrecôte: Publishing companies and disruptive technologies. Trends in communication, v. 11, n. 2, p. 127-136, 2003.

PLUGME. Disponível em <http://www.plugme.com.br/>. Acesso em: 29/06/2008.

POREMBA, Sue Marquette. Take a look at today's vibrant Ebook market. Econtent, v. 31, ed. 31, p.32-37, mar. 2008.

PROJETO GUTENBERG. Disponível em <http://www.gutenberg.org/browse/scores/top>. Acesso em: 05/07/2007.

PUBEASY. Disponível em <http://www.pubeasy.com>. Acesso em: 12/11/2007.

RANDOM HOUSE. Disponível em <http://www.randomhouse.com/madetostick>. Acesso em: 28/06/2008.

REVISTA PANORAMA EDITORIAL. Livro digital: um bom negócio? São Paulo, n. 15, dez. 2005.

SALGADO, Ana Helena Seuánez. O impacto das novas tecnologias na indústria editorial Dissertação de mestrado, Coppead, 2007.

SCRIBD. Disponível em <http://www.scribd.com/> . Acesso em: 02/08/2008.

SHELFARI. Disponível em <http://www.shelfari.com/> Acesso em: 10/12/2008.

SONY READER. $\quad$ Disponível em $<$ http://www.sonystyle.com/webapp/wcs/stores/servlet/CategoryDisplay?catalogId=10551\&st oreId=10151\&langId=-1\&categoryId=8198552921644523779> Acesso em: 06/07/2008.

TEXBOOKSTORRENTS. Disponível em <http://www.textbookstorrents.com/> . Acesso em $02 / 05 / 2008$. 
THE NEW YORK TIMES. Google hope to opens a trove of litlle seen books. Disponível em<http://www.nytimes.com/2009/01/05/technology/internet/05google.html?pagewanted=1\& sq=google $\% 20$ january $\% 2005 \% 202009 \& s t=c s e \& s c p=1>$ Acesso em: 07/03/2009.

THE PUBLISHERS ASSOCIATION. Disponível em $<$ http://www.publishers.org.uk/en/home/>. Acesso em: 02/01/2008.

TREVISAN, Rosana. Moderno dicionário da língua portuguesa. 2007. Disponível em $<$ http://michaelis.uol.com.br/moderno/portugues/index.php?typePag=creditos\&languageText =portugues-portugues $>$ Acesso em: 01/06/2008.

TURBAN, Efraim; KELLY RAINER, R. Jr.; POTTER, Richard E. Administração de tecnologia da informação. São Paulo: Campus, 2005.

VARIAN, Hal R.; FARREL, Joseph; SHAPIRO, Carl. The economics of information technology. Cambridge: Cambridge University Press, 2004.

ZAID, Gabriel. Livros demais! Sobre ler, escrever e publicar. São Paulo: Summus, 2004.

WATERS, Lindsay. Inimigos da esperança. São Paulo: Editora Unesp, 2006. 